\title{
Pau-brasil and string instrument bows telecouple nature, art, and heritage
}

\author{
$\underline{\text { Silke Lichtenberg }}^{1,2}, \underline{\text { Elisabeth Huber-Sannwald }}^{3}, \underline{\text { Juan Antonio Reves-Agüero }}^{4}$, Dieter Anhuf $^{2}$ and $\underline{\text { Udo Nehren }}^{1}$
}

\begin{abstract}
The wood of the pau-brasil tree (Paubrasilia echinata Lam., formerly Caesalpinia echinata Lam.) is used worldwide as raw material for the construction of high-quality bows for string instruments. Alternative tree species are rarely accepted by professional musicians, or by bow and violin makers. Historical overexploitation of this endemic species in the Brazilian Atlantic Forest biome (Mata Atlântica), a global biodiversity hotpot including UNESCO World Natural Heritage Sites, and illegal trade have caused drastic declines in its natural abundance. Pau-brasil is now classified as an endangered species and listed in Appendix II of the Convention on International Trade in Endangered Species. Traditional bow-making craftsmanship, an intangible cultural heritage, depends heavily on the high-quality pau-brasil wood. This complex situation presents unprecedented cross-continental transdisciplinary challenges. In order to target the protection of this coupled natural/cultural heritage, this work frames and examines the pau-brasil/bow-making cultural-ecological system as a complex telecoupled system linked by cultural ecosystem services provided by the pau-brasil, as well as the relationships and cultural exchanges among key actors. Using historical trajectory analysis, we identify past, present, and potential future trigger events, key drivers, and key system variables that explain the dynamics, feedback, and resilience of this complex multidimensional system. Furthermore, with a cross-scale social and power relations analysis, we examine the level of dependencies and influences of contemporary key actors on the ecosystem services provided by the pau-brasil and their interconnections, in order to ultimately identify their level of disadvantage regarding the pau-brasil. Finally, we discuss the potential of this novel cultural-ecological system approach to (i) interlink science, nature, and art, (ii) reconcile the currently competing protection aims of natural and cultural heritage elements, and (iii) provide future trajectories regarding the resilience and sustainable development of this pau-brasil/bowmaking cultural-ecological system. We advocate for this novel path forward toward sustainable transformation of complex culturalecological systems urgently needed to navigate our increasingly telecoupled world.
\end{abstract}

Key Words: bow-making; brazilwood; cultural-ecological system; ecosystem services; intangible cultural heritage; Paubrasilia echinata Lam.; pernambuco wood; social-ecological system

\section{INTRODUCTION}

For more than 200 years, high-quality string instrument bows have been crafted in Europe from the wood of the pau-brasil tree (Paubrasilia echinata Lam.). This endangered tree species is endemic to the Atlantic Forest (Mata Atlântica) biome in Brazil, which is highly fragmented due to historical overexploitation and modern infrastructure development (Dean 1996, Rezende et al. 2018). Decreased population size, conservation measures in the Mata Atlântica biome, and simultaneous trade restrictions on the endangered tree species pau-brasil (CITES 2007) have inevitably led to limited availability of the wood as essential raw material for the construction of high-quality string instrument bows, which directly affects traditional bow-making craftsmanship in Europe (HCA 2021) and classical music as a whole (Rymer 2007). Hence, the interconnection between the ecosystem and natural resource of pau-brasil in the Mata Atlântica and the European bow-making tradition, as well as classical music, forms a historical telecoupled culture-centered social-ecological system or cultural-ecological system.

Crafting musical instruments is the process of transforming raw materials, extracted primarily and traditionally from wild populations of intact ecosystems, into objects of art for making music - a historically rooted interconnection between nature, art, and heritage elements. Cultural and natural heritage concepts consider the historical, current, and future importance
(Lowenthal 2005) of certain cultural traditions or artefacts and natural environments (Richards et al. 2020) or cultural landscapes (Taylor and Lennon 2011), respectively with outstanding (tangible or intangible) universal value and exceptional significance for humanity (see heritage definitions in Table A1.1), with or without official declaration by the United Nations Educational, Scientific and Cultural Organization (UNESCO). However, the official recognition of heritage is important for achieving place-based conservation and sustainable development (UNESCO 2019b). UNESCO has been declaring the world's material, cultural, and natural heritage sites and elements since 1975; in 2006, the category of intangible cultural heritage was included. Although the UNESCO list of intangible cultural heritage does not explicitly include music, approximately $70 \%$ of the list is directly or indirectly related to music (Pinto 2018) and musical instruments.

Historically rooted interconnections between culture and nature are acknowledged in the form of biocultural heritage (Lindholm and Ekblom 2019). Biocultural diversity, assets, and heritage (see definitions in Table A1.1) refer to the linkage between people and nature or human cultural and biological diversity (Bridgewater and Rotherham 2019). Biocultural approaches within sustainability science incorporate a social-ecological system's understanding (Merçon et al. 2019). However, these concepts are limited to place-based contexts (Bridgewater and Rotherham

${ }^{1}$ Institute for Technology and Resources Management in the Tropics and Subtropics (ITT), TH-Köln - University of Applied Sciences, Köln, Germany, ${ }^{2}$ Department of Geography, University of Passau, Passau, Germany, ${ }^{3}$ Division of Environmental Sciences, Instituto Potosino de Investigación Científica y Technológica, A.C. (IPICYT), San Luis Potosí, SLP, Mexico, ${ }^{4}$ Instituto de Investigación de Zonas Desérticas, Universidad Autónoma de San Luis Potosí, San Luis Potosí, SLP, Mexico 
2019, Hanspach et al. 2020). European colonization initiated cross-continental relationships between distant territories, which in the case of instrument making, are ultimately the reason why certain parts of musical instruments from the Global North are traditionally made from tropical wood from the Global South. Since colonial times, these cross-scale social, commercial, and power relations have increasingly impacted the availability and use of certain ecosystem goods and services, such as pau-brasil wood for bow making. Understanding these social-ecological linkages and interdependencies across scales is a prerequisite for identifying the levels of disadvantages of key actor groups and achieving distributional and procedural equity with respect to ecosystem services (Martín-López et al. 2019), which ultimately leads to a transformation toward fair, equitable, and sustainable development that takes all affected actors into account.

If stringed instruments and their bows are grouped together in one category, $10 \%$ of them are made from tropical wood (Elsasser et al. 2011), while if one considers only modern string instrument bows, nearly all materials originate from the tropics. To our knowledge, currently none of the existing analytical frameworks permit the examination of cross-continental interlinkages among ecosystems, species, actors, culture, and art. We propose a telecoupled cultural-ecological systems (CESs) approach inspired by the telecoupled social-ecological systems framework of Liu et al. (2013), but with a focus on culture. To address the multidimensional and cross-scale roles of the pau-brasil tree species in delivering goods, services, and additional contributions, we adopted nature's contributions to people (NCPS) (Pascual et al. 2017, Díaz et al. 2018) and ecosystem services (ESs) (MEA 2005) as complementary frameworks, in line with Pires et al. (2020). Consequently, we call for a new inclusive concept of cultural ecosystem services that encompasses both non-material (cultural) and material services. Further, we advocate for the broadening of the established ecosystem services framework and introduce the concept of "provisioning-cultural services". This addition is consistent with and supports the separation into tangible and intangible cultural heritage, thus allowing for a coherent analysis of cultural-ecological systems that integrate the NCP and ES frameworks and cultural and natural heritage (see definitions in Table A1.1). This scope enables an overarching analysis of the complex historical, cultural-ecological, telecoupled relations between humans and nature, as well as crossscale power relationships that connect local ecosystems with culture and art, in the context of system-defining key ecological and cultural elements and key actors (Fig. 1, Table A2.1).

In this exploratory research study, we analyzed the interrelations between the cultural-ecological subsystem A (CES-A), the Brazilian Mata Atlântica with the pau-brasil tree as a key ecological element, and the cultural-ecological subsystem B (CES-B) with European traditional bow making (cultural practice), classical music (cultural expression), and string instrument bows (cultural objects) as key cultural elements, including the contemporary key actors of both subsystems (Fig. 1). The goal was to disentangle and unveil the complexity of this telecoupled pau-brasil/bow-making cultural-ecological system (PB-CES) and its sources of resilience in order to propose pathways for sustainable development and the protection of this telecoupled cultural-ecological system. The extraordinary natural and cultural values of the subsystems are evidenced by
UNESCO's nominations of Mata Atlântica reserves as Natural World Heritage Sites (1999, 2001, 2019; see Table 1), and independently "Traditional violin craftsmanship in Cremona" in Italy as an intangible cultural heritage (in 2012), the latter being closely linked to traditional craftsmanship of string instrument bows. Cross-continental solutions are needed in order to safeguard these interlinked natural and cultural heritage elements and to avoid the crossing of "cultural-ecological tipping points" (see definition in Table A1.1). Maintaining the integrity of traditional bow making in Europe, embedded in the CES-B, and the high-quality pau-brasil wood from the Mata Atlântica, as part of the CES-A, contributes to the resilience of this telecoupled cultural-ecological system (Fig. 1).

Sustainable solutions require a thorough understanding of the dynamics of key NCPs/ESs provided by the pau-brasil tree, and the drivers of the interconnections and feedback among classical music and the violin- and bow-making tradition, as well as the natural environments and socio-political and economic contexts locally and across continents. The importance of species-specific contributions to NCPs/ESs has been highlighted in the literature (Luck et al. 2009); e.g., as an indicator (Abualhagag and Valánszki 2020) or symbolic species (Schirpke et al. 2018), or as culturally defined keystone species (Cristancho and Vining 2004), cultural keystone species (Garibaldi and Turner 2004), or social-ecological keystone species (Winter et al. 2018). Therefore, we focus on key NCPs/ESs provided by pau-brasil trees growing in natural Mata Atlântica ecosystems and their benefits to humans in a global and historical context, and their role in the pau-brasil/bow-making cultural-ecological system, considering the contemporary social and power relations of key actors. This research is transdisciplinary (Brandt et al. 2013) in that it includes knowledge, worldviews, and perspectives of various stakeholders and key actors based on inquiry through interviews and surveys. The synergistic value of interweaving different knowledge systems (local knowledge of farmers, woodcutters, and wood dealers in the Mata Atlântica, traditional craftsmanship knowledge, interdisciplinary social-ecological knowledge, technical knowledge of wood sciences, artistic knowledge of musicians regarding requirements for string instrument bows) enriches the overall picture (Tengö et al. 2014) and ultimately permits an integrated assessment of complex telecoupled cultural-ecological systemsin our case, of the PB-CES.

With the telecoupled cultural-ecological systems approach (Fig. 1), we address the following research questions considering the Mata Atlântica, Europe, and global scale:

1. How have complex system dynamics shaped the integrity and resilience of the telecoupled pau-brasil/bow-making cultural-ecological system along its historical trajectory, considering the evolution of classical music, violin and bow making, transformation of the natural environment, and changes in socio-political and economic contexts?

2. How do contemporary cross-scale social and power relations among key actors and stakeholders of the PB-CES influence the delivery of pau-brasil's NCPs/ESs and consequently human well-being?

Based on our findings, we discuss possible future trajectories with respect to the resilience and sustainable development of the PB- 
Fig. 1. Conceptual framework of a telecoupled cultural-ecological system with six principal units: (1) geographically distant cultural-ecological subsystems (CES-A, CES-B), each consisting of system-defining key ecological (e.g., single or set of species) and cultural (e.g., traditional craft, art, rituals, and the related key actors) elements (inner circles and hexagons, respectively); (2) people's values of nature and culture resulting from the interactions between nature and culture; they shape the mindsets at the level of (i) ecosystems, considering instrumental, relational, and intrinsic values (inherent to every living being by its mere existence) and at the level of (ii) culture, considering the sequential (thin unidirectional orange arrows) interconnections between cultural practices (intangible/non-material; knowledge for creating something material such as traditional craftsmanship or the knowledge of preparing traditional medicine), cultural goods (tangible, movable/unmovable), and cultural expressions (intangible/non-material), as well as through (3) cultural exchange and relationships/interactions among key actors of the two subsystems (CES-A, CES-B; orange bidirectional arrow) and cross-continental cultural influences on the key ecological element(s) (dashed orange unidirectional arrow); (1)-(3) contribute to the emerging telecoupled cultural-ecological system; (4) the system dynamics encompass triggers, drivers, and feedback in relation to key system variables that shape the telecoupled system states, as well as thresholds/tipping points that can induce entire regime shifts; (5) the whole telecoupled cultural-ecological system is influenced by exogenous controls and drivers such as climate change, international markets, legislation, treaties, etc. (see potential examples of telecoupled culturalecological systems in Table A2.1). (NCPs = nature's contributions to people).

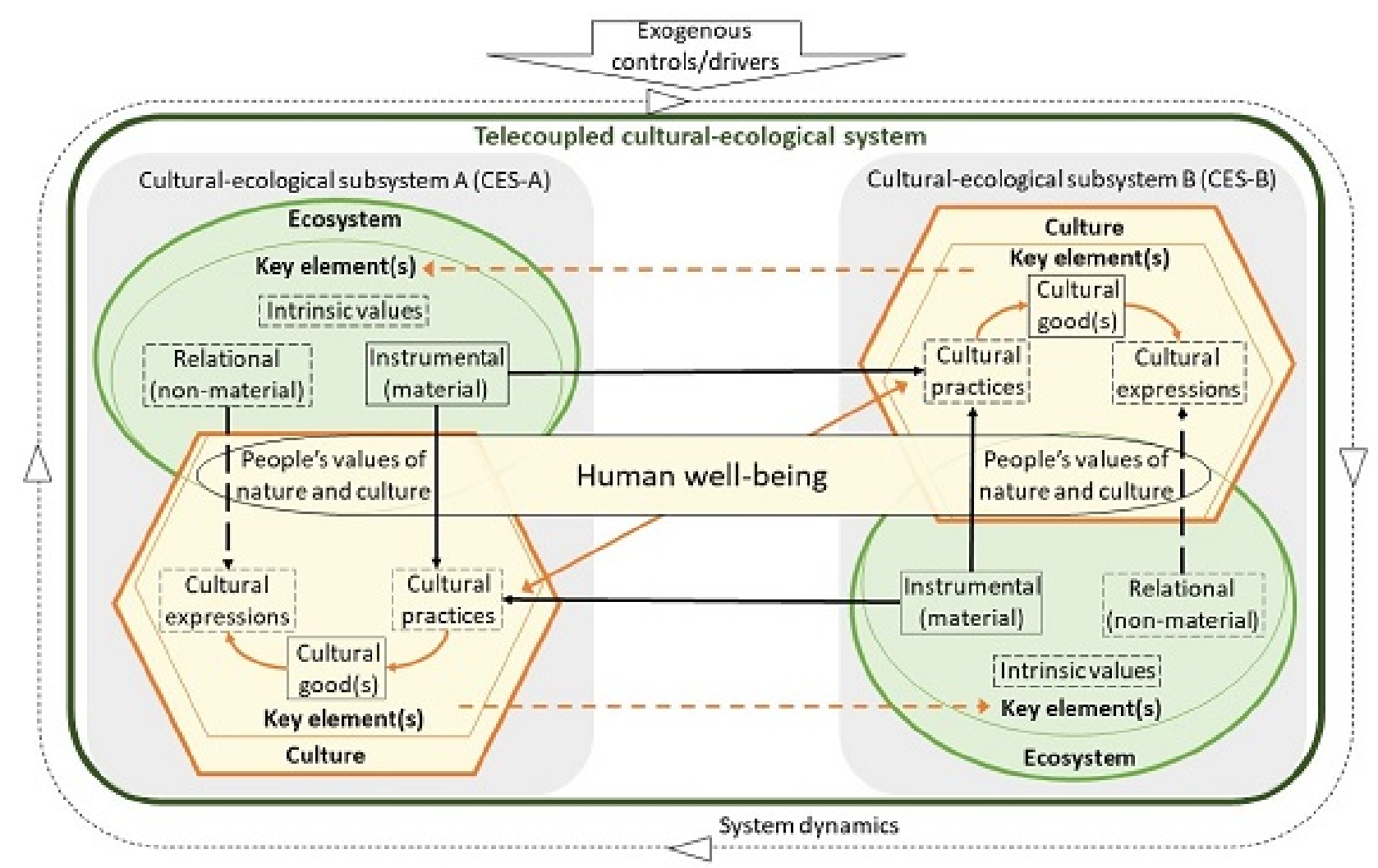

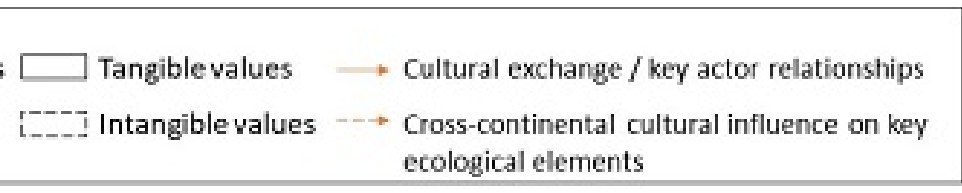

CES. Overall, this study aims to elucidate the mechanisms underlying the integrity, resilience, and sustainable development of the PB-CES. To our knowledge, this is one of the first studies to indicate that complex sustainability challenges require not only novel research approaches but also new telecoupled, transdisciplinary perspectives and thus frameworks to recognize and scrutinize such unexpected yet strong linkages between nature and art across continents.

\section{METHODS}

Telecoupled cultural-ecological systems analysis

The in-depth PB-CES analysis (Fig. 2) identifies key intercontinental relations between (i) the Mata Atlântica in Brazil 
Table 1. Fact sheet on the Mata Atlântica biome and pau-brasil

\begin{tabular}{|c|c|c|c|}
\hline & Description & Attributes & Source \\
\hline \multirow[t]{5}{*}{ Mata Atlântica } & Original extent of biome in Brazil & Approx. 1.3 million $\mathrm{km}^{2}$ & $\begin{array}{l}\text { Mapa da Área de Aplicação da } \\
\text { Lei } \mathrm{n}^{\circ} 11.428 \text {, de } 2006 \text { (IBGE } \\
\text { 2006) }\end{array}$ \\
\hline & Current area covered by original biome & $28 \%$ & Rezende et al. 2018 \\
\hline & Biodiversity hotspot: known plant species & 19,355 & Forzza et al. 2012 \\
\hline & Endemic plant species & 7646 & Forzza et al. 2012 \\
\hline & Endangered plant species & 1544 & Martinelli and Moraes 2013 \\
\hline \multirow{4}{*}{$\begin{array}{l}\text { Natural World Heritage } \\
\text { sites within Mata Atlântica }\end{array}$} & Atlantic Forest South-East Reserves ( 25 protected areas) & $4.68 \mathrm{~km}^{2}$ & UNESCO 1999 \\
\hline & $\begin{array}{l}\text { Discovery Coast Atlantic Forest Reserves ( } 8 \text { protected areas); the } \\
\text { only natural heritage site within pau-brasil's natural distribution } \\
\text { area }\end{array}$ & $1.12 \mathrm{~km}^{2}$ & UNESCO 1999 \\
\hline & $\begin{array}{l}\text { Brazilian Atlantic Islands: Fernando de Noronha and Atol das } \\
\text { Rocas Reserves ( } 2 \text { protected areas/islands) }\end{array}$ & $0.42 \mathrm{~km}^{2}$ & UNESCO 2001 \\
\hline & $\begin{array}{l}\text { Paraty and Ilha Grande - Culture and Biodiversity ( } 4 \text { protected } \\
\text { areas) }\end{array}$ & $1.73 \mathrm{~km}^{2}$ & UNESCO 2019a \\
\hline \multirow[t]{6}{*}{$\begin{array}{l}\text { Pau-brasil (Paubrasilia } \\
\text { echinata Lam.) }\end{array}$} & $\begin{array}{l}\text { Occurrence: In semi-deciduous forests on sandy soils along the } \\
\text { coastline of Rio Grande do Norte to Rio de Janeiro at low } \\
\text { altitudes; historically, abundant semi-deciduous tree species; } \\
\text { currently, natural populations only in remote forest fragments. } \\
\text { Climax species, slow growth, strong hardwood, non-N-fixing } \\
\text { legume }\end{array}$ & 4 trees/ha & $\begin{array}{l}\text { Cronquist 1992, Dean 1996, } \\
\text { Sprent and Parsons 2000, } \\
\text { CITES } 2007\end{array}$ \\
\hline & Monospecific genus & Paubrasilia & Gagnon et al. 2016 \\
\hline & Tree height & $5-15+m$ & Gagnon et al. 2016 \\
\hline & Maximum stem diameter & $0.7 \mathrm{~m}$ & Cordero and Mello 2008 \\
\hline & Earliest harvest of planted trees for bow making & after 30 years & Marques et al. 2012 \\
\hline & Range of wood density & $855-1197 \mathrm{~kg} / \mathrm{m}^{3}$ & Schimleck et al. 2009 \\
\hline \multirow{9}{*}{$\begin{array}{l}\text { Pau-brasil wood for string } \\
\text { instrument bows }\end{array}$} & Global wood demand & $200 \mathrm{~m}^{3} /$ year $\dagger$ & CITES 2007 \\
\hline & $\begin{array}{l}\text { Material wood demand for one bow } \\
\text { Final weight of a violin bow stick } \\
\text { Specific gravity for high-quality bows (at } 12 \% \text { humidity) }\end{array}$ & $\begin{array}{l}1 \mathrm{~kg} / \mathrm{bow} \\
\sim 37 \mathrm{~g} \\
<950 \mathrm{~kg} / \mathrm{m}^{3}\end{array}$ & $\begin{array}{l}\text { CITES } 2007 \\
\text { weighted out } \\
\text { Alves et al. } 2008 \text {, Longui et al. } \\
2010\end{array}$ \\
\hline & Speed of sound propagation for high-quality bows & $<4300 \mathrm{~m} / \mathrm{s}$ & Alves et al. 2008 \\
\hline & Modulus of elasticity for high-quality bows & $<17,652 \mathrm{MPa}$ & Alves et al. 2008 \\
\hline & Modulus of rupture for high-quality bows & $<196 \mathrm{Mpa}$ & Alves et al. 2008 \\
\hline & Mean shearing strength & $22.5 \mathrm{Mpa}$ & Matsunaga and Minato 1998 \\
\hline & $\begin{array}{l}\text { Anatomical wood characteristics for high-quality bows } \\
\text { Vessel diameter/vessel element length/vessel frequency }\end{array}$ & $\sim 110 \mu \mathrm{m} / 350 \mu \mathrm{m} / 13 \mathrm{~mm}^{-2}$ & Longui et al. 2010 \\
\hline & Ray height/ray width/frequency & $\sim 230 \mu \mathrm{m} / 20 \mu \mathrm{m} / 10 \mathrm{~mm}^{-1}$ & Longui et al. 2010 \\
\hline & Fiber length/diameter/lumen diameter/wall thickness & $\begin{array}{l}\sim 1160 \mu \mathrm{m} / 18 \mu \mathrm{m} / 5 \mu \mathrm{m} / \\
6 \mu \mathrm{m}\end{array}$ & Longui et al. 2010 \\
\hline
\end{tabular}

${ }^{\dagger}$ Based on the material demand for one bow ( $\left.1 \mathrm{~kg} / \mathrm{bow}\right)$ and average wood density $\left(1026 \mathrm{~kg} / \mathrm{m}^{3}\right)$, approximately 205,026 string instrument bows/year are produced worldwide (not considering wood moisture content).

as natural heritage (Fig. 1, CES-A) with its endemic pau-brasil tree (Fig. 1, key ecological element), and (ii) traditional bowmaking craftsmanship and classical music (Fig. 1, key cultural elements) in Europe as intangible cultural heritage (Fig. 1, CESB). The analysis of the different data sources was an interconnected iterative process that served to answer both research questions (Fig. 3).

Historical trajectory analysis

The temporal analysis of the origin and development of the PBCES began shortly before the European conquest of Brazil (1500) and continues today; it encompasses three spatial scales: (i) the Mata Atlântica biome as the habitat of the pau-brasil (Fig. 1, CES-A), (ii) Europe as the cradle of classical music and traditional bow-making craftsmanship (Fig. 1, CES-B), and (iii) the global scale with its exogenous controls and drivers acting on the PB-CES. We simultaneously explored the historical development of four thematically interrelated dimensions at three defined scales of the PB-CES: (a) classical music, (b) traditional violin and bow making, and (c) modification of the natural environment through land use and extraction of natural resources, all in the context of changing (d) socio-political and economic contexts (Fig. 4). This multi-layered analysis served to identify (A) the key ecological elements of the CES-A (Fig. 1), (B) the key cultural elements of the CES-B (Fig. 1), (C) the system boundaries, and (D) PB-CES properties, such as the key trigger events, drivers, system variables, and feedback that explain the stability of system states, thresholds, and regime shifts of the PBCES (Figs. 2, 3). The information base for this analysis came from (1) a narrative literature review (Table A3.1), (2) semi-structured interviews with key actors and experts (Tables A4.1, A4.2), (3) an international online survey (Table A5.1), and (4) field visits to pau-brasil plantations (Figs. 2, 3; Table 2). 
Table 2. Description of the applied methodological approaches to examine the pau-brasil/bow-making cultural-ecological system (PBCES). For each method, Roman numerals in parenthesis indicate whether the method served to respond to the research question related to (I) the historical trajectory and/or (II) the contemporary cross-scale social and power relations of key actors and stakeholders.

\begin{tabular}{|c|c|}
\hline Method & Description of the methodological approach \\
\hline $\begin{array}{l}\text { Literature review } \\
(\mathrm{I}+\mathrm{II})\end{array}$ & $\begin{array}{l}\text { Narrative (non-systematic) review (Ferrari 2015) including scientific publications from different disciplines, specialist literature from } \\
\text { violin and bow makers, archived historical records (e.g., trade data from craft guilds), and public databases (e.g., CITES trade } \\
\text { database) as (I) context-related historic basis (Table A3.1) and (II) to identify pau-brasil's key nature's contributions to people/ } \\
\text { ecosystem services, as well as the benefiting actor groups, with a special focus on key actor groups from our four thematic dimensions. }\end{array}$ \\
\hline $\begin{array}{l}\text { Semi-structured } \\
\text { interviews } \\
\text { (I+II) }\end{array}$ & $\begin{array}{l}\text { Interviewee selection }(n=34) \text { and identification of key actors and experts (scientists and environmental agencies) forming part of the } \\
\text { PB-CES in the Mata Atlântica, Brazil and in Europe (Germany and Spain) were based on the snowball sampling technique (Coleman } \\
\text { 1958) (Table A4.1). Application during two field visits in Brazil in } 2015 \text { and 2018/19 to identify (I) changes or shifts in social/cultural } \\
\text { system variables and their drivers, considering time and scale, and (II) stakeholder- and actor-specific dependencies of pau-brasil } \\
\text { nature's contributions to people/ecosystem services, influences on decision-making processes affecting pau-brasil's nature's } \\
\text { contributions to people/ecosystem services, as well as key actor interconnections and interdependencies. }\end{array}$ \\
\hline $\begin{array}{l}\text { International online } \\
\text { survey } \\
\text { (I) }\end{array}$ & $\begin{array}{l}\text { The elaboration was based on the principles and methods for surveys presented by Sutherland et al. (2011). In total, } 1882 \text { companies } \\
\text { (tone wood dealers, string producers, and dealers of musical instruments and accessories), bow makers, and violin makers were } \\
\text { invited to respond (Appendix 5); their contact information was obtained from the 'Strad directory' (The Strad 2014). The survey was } \\
\text { designed in six languages (English, French, German, Italian, Portuguese, and Spanish) with an online application (www. } \\
\text { umfrageonline.com) and encompassed in total } 54 \text { (open-ended and close-ended) questions; due to the flexible and respondent- } \\
\text { adapted structure each respondent had to answer only a fraction of the questions. The survey was sent in 2014, and a reminder e-mail } \\
\text { was sent two weeks later to the companies that had not yet participated in the survey. However, this study is based on only six selected } \\
\text { close-ended questions. The return rate of the survey was } 18.1 \%(n=340) ; 340 \text { respondents completed the survey (Appendix 5). The } \\
\text { respondents can be divided as follows: } 67.6 \% \text { were violin makers, } 40.9 \% \text { were dealers of string instruments and accessories, } 25.3 \% \\
\text { were bow makers, and } 9.1 \% \text { were others. The survey focused on the knowledge/understanding of existing interconnections, and } \\
\text { perceptions of and influence on pau-brasil populations and bow making; it complemented the qualitative information gained from } \\
\text { the interviews. }\end{array}$ \\
\hline $\begin{array}{l}\text { Field visits } \\
\text { (I) }\end{array}$ & $\begin{array}{l}\text { During the two field visits in Brazil in } 2015 \text { and } 2018 / 19 \text {, a total of } 15 \text { pau-brasil plantations were visited (Rio Grande do Norte [1], } \\
\text { Paraíba [1], Pernambuco [2], Bahia [5], Espírito Santo [6]) to examine the extent, type (monoculture, agroforestry, mixed-tree } \\
\text { plantation), and status of the plantations (officially registered in the rural environmental cadastre (Cadastro Ambiental Rural - } \\
\text { CAR), planted in a private conservation area or registered as an agricultural area, existing/non-existing management plan) to estimate } \\
\text { the relevance and historical development of these plantations and the possible future economic importance. }\end{array}$ \\
\hline $\begin{array}{l}\text { Personal observations } \\
\text { of participants } \\
\text { (II) }\end{array}$ & $\begin{array}{l}\text { A three-day workshop entitled "Conservation and Promotion of Pernambuco (syn. pau-brasil) in the Northeast of Brazil" explored } \\
\text { shared experiences and potential solutions. It was held in April } 2015 \text { in João Pessoa, Paraiba in Brazil, organized by the Associação } \\
\text { Plantas do Nordeste, and financed by the International Pernambuco Conservation Initiative. Workshop participants }(n=19) \text { came } \\
\text { from Brazil, Germany, France, and the United States, and represented bow makers, environmental NGOs, scientists, and policy- } \\
\text { makers. During the workshop, we identified the participants' geographic origin and their affiliation with the identified key actor } \\
\text { groups, and we observed the participants' interactions (e.g., intensity/frequency of conversations between actors of the same or } \\
\text { different actor groups), level of communication (e.g., top-down, horizontal), participation in discussions (e.g., frequency of questions } \\
\text { and origin of actor group), and decision-making processes (e.g., decisions based on voting processes) (for details, see Appendix 6). } \\
\text { The observations complemented the findings of the semi-structured interviews regarding the level of influence of key actor groups } \\
\text { (see matrix in Table A6.3). }\end{array}$ \\
\hline
\end{tabular}

Cross-scale social and power relations analysis

To understand potential (inter)dependencies, power asymmetries, and interconnections of key actor groups (agents, sensu Liu et al. 2013) regarding NCP/ES flows of pau-brasil (Fig. 5) over the last 30 years at three spatial scales-Mata Atlântica (Fig. 1, CES-A), Europe (Fig. 1, CES-B), and internationally-our data acquisition encompassed (1) semi-structured interviews (Appendix 4) based on the snowball sampling technique (Coleman 1958); (2) a narrative (non-systematic) literature review (Table A3.2) (Ferrari 2015), and (3) personal observations of workshop participants (Table 2). Participant observation is a common research method in sociology; according to Becker and Geer (1957) it is "the most complete form of the sociological datum," especially suited to assess relationships between actors, and an important tool for assessing key actors' relationships (Martín-López et al. 2019). The comprehensive "cross-scale influence-dependence framework" (Martín-López et al. 2019) allowed us to determine (i) contemporary (1990-2020) levels of dependencies of key actors on the NCPs/ESs of pau-brasil for their livelihoods in the Mata Atlântica (Fig. 1, CES-A), Europe (Fig. 1, CES-B), and internationally, and/or (ii) related values of key actors' influences on decision-making processes regarding the management of pau-brasil's NCPs/ESs, and (iii) cross-scale interactions between key actor groups (Fig. 6). Accordingly, we followed steps (a) to (d) in Table 3 and applied the criteria described in our interconnected data analysis (Fig. 3). By combining the dependency and influence levels of the key actor groups, we created dependency-influence matrices (Fig. 7) for the Mata Atlântica (Fig. 1, CES-A), Europe (Fig. 1, CES-B), and global scale (Appendix 6). With these depictions, we identified the level of disadvantages of each actor group with respect to the losses of pau-brasil's NCPs/ESs.

\section{RESULTS}

\section{Historical trajectory of the pau-brasil/bow-making cultural- ecological system}

We conceptualized the system dynamics of the PB-CES through five regimes (between the end of the 15 th century and the present), a series of key trigger events (T1-T5), drivers (D1-D13), key system variables (S1-S15), and feedback types (F1-F13) (Table 4), considering important cross-scale interactions (temporal, 
Fig. 2. Methodological steps for an integrated analysis of the telecoupled pau-brasil/bow-making cultural-ecological system (PBCES). (MA = Mata Atlântica, NCPs = nature's contributions to people, ESs = ecosystem services).

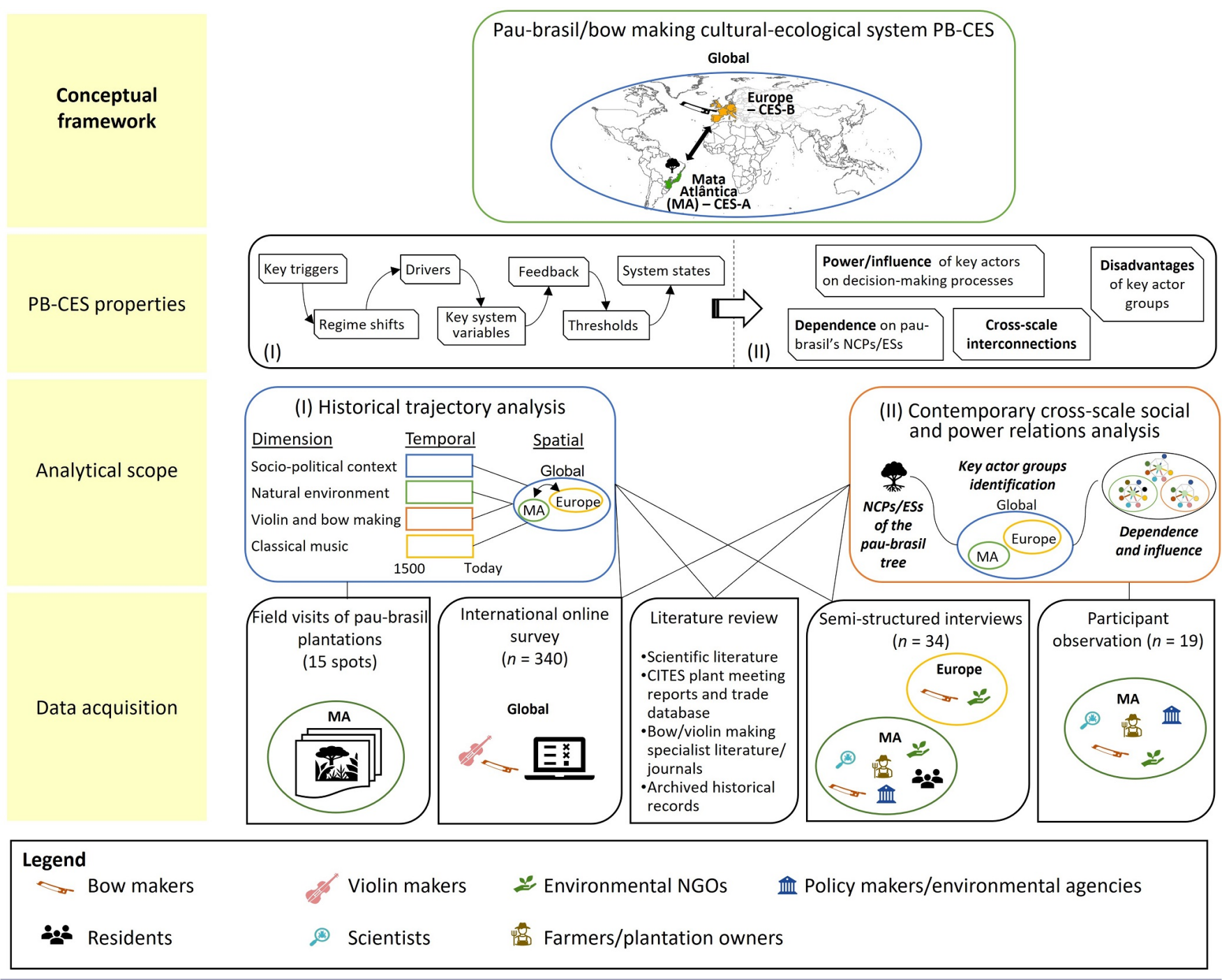

spatial, and dimensional) (Fig. 4). To facilitate transdisciplinary accessibility, we provide a detailed description of the historical trajectory of the PB-CES in Appendix 7.

Pre-colonial ecocultural system in the Mata Atlântica and socialecological system within Europe (before 1500)

The pre-colonial Mata Atlântica social-ecological systems can be described as a resilient ecocultural system (see definition in Table A1.1), considering that the land use of the Tupí and Guarani tribes was based mainly on shifting cultivation, hunting, and fishing, which was unlikely to lead to significant land degradation under low population pressure (Nehren 2011), thus characterizing a sustainable social-ecological regime (Table 4-F1). In contrast, the social-ecological system in Europe was close to an ecological threshold, when considering Moore's (2002) noted overexploitation of natural resources from a systems perspective (Table 4-D1, S1, F2). Portuguese colonization of Brazil (trigger T1; Table 4-T1; Fig. 4-T1) caused the crossing of several thresholds, such as geographical distance, Indigenous autonomy, and the sustainable use of the Mata Atântica ecosystem, giving rise to the new crosscontinental social-ecological system.

Pau-brasil exploitation for dyes (1500 to 1800)

Upon the European discovery of Brazil, the exploitation of paubrasil wood (Table 4-D2) began. Its high brazilin concentration, a red pigment used as textile dye, soon replaced the pigment extracted from the Asian Caesalpinia sappan L. (Aguiar and Pinho 2007). This caused severe reductions and ecological degradation of the Mata Atlântica biome (Table 4-S3) (Dean 1996, Galindo-Leal and Câmara 2005, Nehren et al. 2013). In the 16 th century alone, approximately $6000 \mathrm{~km}^{2}$ were destroyed (Dean 1996). The pau-brasil's growing economic importance prompted the Portuguese to name their colony "Terra do Brasil" (Rocha et al. 2007). Between 1500 and 1800, 466,518 pau-brasil trees (Fig. 1, key ecological element) were exported to Europe (Rocha 2008). Local communities (often as slaves), especially the 
Fig. 3. Interconnected data analysis for the pau-brasil/bow-making cultural-ecological system (PB-CES), adopting five quantitative and qualitative methods (see text inside circles). For an iterative historical trajectory analysis, see lightcolored rounded rectangles (A)-(D) with key determinants (A-C) and properties (D) of the PB-CES. For the determinants of contemporary social and power relations analysis (Table 3), see the light-colored rounded rectangle (a)-(d). For final results of the interconnected data analysis responding to research questions, see the dark-colored rounded rectangles (I and II). Rectangles depict analytical steps. Arrows guide the sequence of data analysis. Orange arrows (1)-(4) refer to key processes for defining the analytical scope (1 and 2) and PB-CES properties (3 and 4) of data analysis (see Fig. 2). (1) Determination of focal key ecological and cultural elements as first findings from the narrative literature review; (2) First descriptive historical trajectory allows the definition of system boundaries as an entry point for the identification of experts on pau-brasil within the focal scale; (3) Modified historical trajectory identifies PBCES properties; (4) Jointly, narrative literature review, interviews, and participant observations lead to the identification of key actors. Black arrows: dashed arrows refer to the iterative feedback loop to update the first descriptive historical trajectory; continuous lined arrows complete the sequential process of data analysis. (NCPs = nature's contributions to people, ESs = ecosystem services).

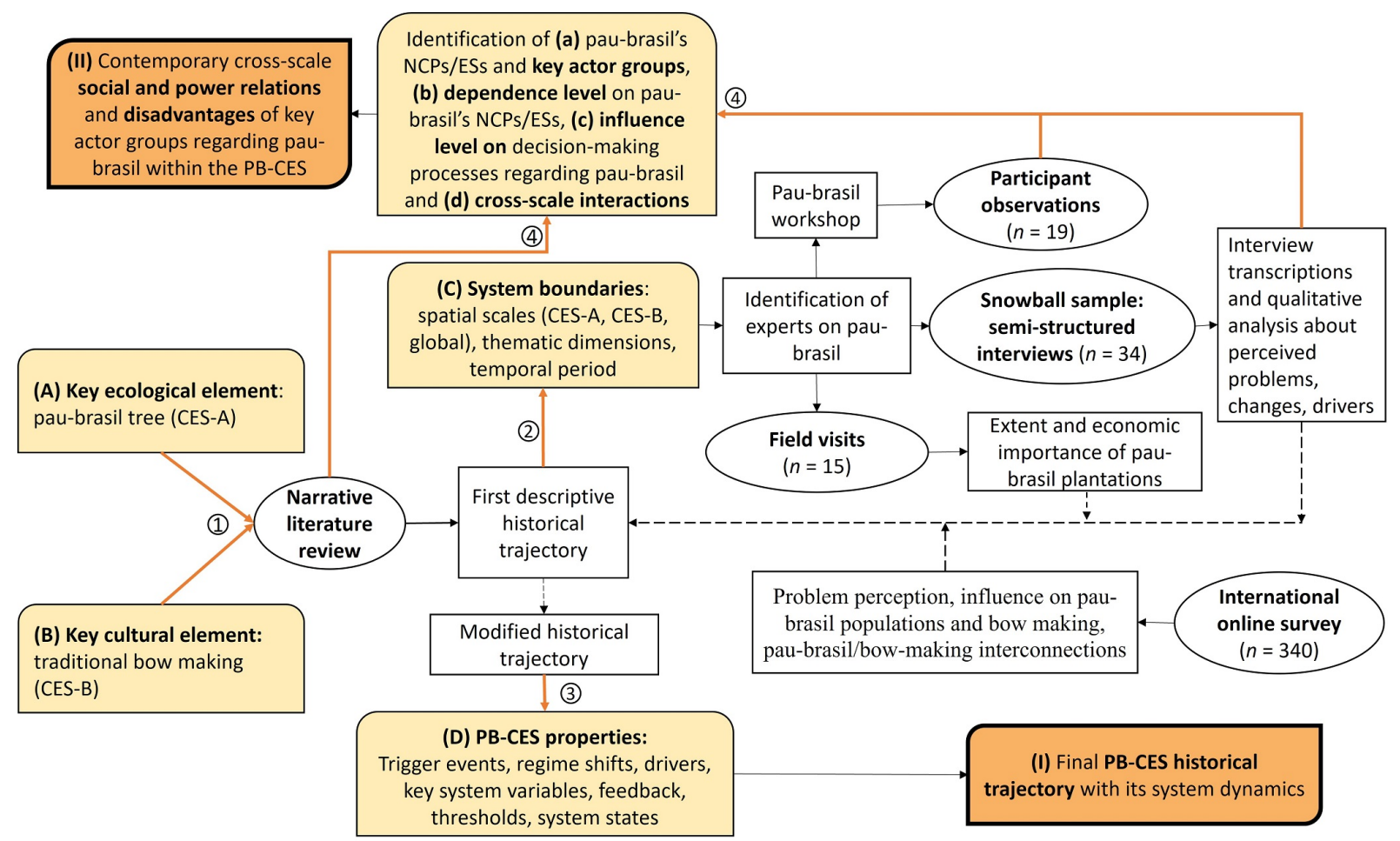

Tupí tribe, were involved in the Portuguese pau-brasil trade (Dean 1996); however, they also started clandestine trading with France (Dean 1996, Montaigne 2000). Around 1500, the tradition of violin making (slow key cultural system variable; Table 4-S3) developed in Europe (Schebeck 1877). Increasing accessibility to music played by string instruments (slow key cultural system variable) to the European general public (Table 4-D3) required progress and innovation (Table 4-S4) in the construction of musical instruments (Table 4-F5; Fig. 4-T2), marking a new cultural threshold in violin making, internally driven by technocultural advances: the invention of "modern violin bows," which gave rise to the telecoupled PB-CES (Fig. 1).

The invention of the "modern violin bow" gives rise to the telecoupled pau-brasillbow-making cultural-ecological system ( 1800 to $\sim 1900)$

At the end of the 18th century, bow maker François Xavier Tourte (1747-1835) encountered pau-brasil wood in Paris, an important center of textile dyeing; he innovated the construction of string instrument bows (trigger T2; Fig. 1, CES-B, key cultural element, cultural practices; Table 4-T2; Fig. 4-T2). Soon the new "modern violin bow" model with its concave-shaped stick revolutionized the construction of violin bows; these high-quality bows (Fig. 1, CES-B, cultural object) were made exclusively of pau-brasil wood (see wood characteristics for string instrument bows in Table 1; Fig 1, key ecological element of CES-A, material value, material $\mathrm{NCP} /$ provisioning-cultural service) (Baines 1961, Longui et al. 2010). The craft quickly became established throughout Europe (Fig.1, CES-B, key cultural element, cultural practices), creating the basis for the telecoupled PB-CES. However, the convexshaped baroque bows, which until then had been constructed from native European wood and other tropical species by violin makers, were never fully replaced (Baines 1961, Longui et al. 2010, Brémaud and Poidevin 2013). In the 18th century, the expansion of coffee plantations caused a substantial reduction of the Mata Atlântica. However, pau-brasil exploitation dropped drastically 
Table 3. Stepwise approach and criteria for the application of the social and power relations analysis of key actor groups of the paubrasil/bow-making cultural-ecological system (PB-CES) (Martín-López et al. 2019). Levels of dependence and influence of key actors on pau-brasil's nature's contributions to people/ecosystem services (NCPs/ESs) within and across the scales of Mata Atlântica (CESA), Europe (CES-B), and the global scale served as the basis for assessment of the interconnections.

\begin{tabular}{|c|c|c|}
\hline & Steps & Criteria \\
\hline (a) & $\begin{array}{l}\text { Identify pau-brasil's key NCPs/ESs and define group affiliations } \\
\text { regarding the professional activities of the most relevant actor groups } \\
\text { of the PB-CES at different scales (global, Europe [Fig. 1, CES-B], } \\
\text { Mata Atlântica [Fig. 1, CES-A]). We focused on the key actor groups } \\
\text { (Fig. 6). }\end{array}$ & $\begin{array}{l}\text { Identification of (1) material/provisioning and provisioning-cultural ESs } \\
\text { and non-material NCPs (cultural ecosystem services) of the pau-brasil tree } \\
\text { through literature review, (2) actor groups that benefit from these NCPs/ESs } \\
\text { identified through literature review and interview responses, and (3) most } \\
\text { relevant actor groups identified through literature review and information } \\
\text { feedback on important actors from the semi-structured interviews and } \\
\text { professional group affiliations. Key actor groups were chosen, representing } \\
\text { one of the four dimensions of our PB-CES (Fig. 6). }\end{array}$ \\
\hline (b) & $\begin{array}{l}\text { Define the dependency level (see definition in Table A1.1 and the } \\
\text { matrix in Table A6.3) of each key actor group on a set of NCP/ES of } \\
\text { pau-brasil at all scales (global, Europe [Fig. 1, CES-B], and Mata } \\
\text { Atlântica [Fig. 1, CES-A]). }\end{array}$ & $\begin{array}{l}3=\text { highly dependent on material and non-material NCPs/ESs provided by } \\
\text { pau-brasil for livelihoods of actor groups within the Mata Atlântica, } \\
\text { Europe, and globally; } 2=\text { moderately dependent on pau-brasil's immaterial } \\
\text { NCPs/ESs; } 1 \text { = low dependence on pau-brasil as a species, as the topic of } \\
\text { their work is replaceable (science, environmental NGOs, environmental } \\
\text { agencies). }\end{array}$ \\
\hline (c) & $\begin{array}{l}\text { Define the level of influence (see definition in Table A1.1) of each key } \\
\text { actor group on management or policy decisions affecting NCPs/ESs of } \\
\text { pau-brasil at all scales (global, Europe [Fig. 1, CES-B], Mata Atlântica } \\
\text { [Fig. 1, CES-A]). }\end{array}$ & $\begin{array}{l}3=\text { very large influence through active participation in decision-/policy- } \\
\text { making processes related to the management of NCPs/ESs implemented and } \\
\text { mediated by formal institutions (e.g. laws, regulations, conventions); } 2= \\
\text { moderate (subtle) influence (e.g., on social and cultural narratives/ } \\
\text { discourses); } 1=\text { limited influence (e.g., through knowledge distribution } \\
\text { regarding pau-brasil); } 0=\text { no influence. }\end{array}$ \\
\hline (d) & $\begin{array}{l}\text { Define potential cross-scale interactions (global, Europe [Fig. 1, CES- } \\
\text { B], Mata Atlântica [Fig. 1, CES-A]) among key actors and actor } \\
\text { groups (e.g., information, business exchanges/cooperation, exchange of } \\
\text { goods, etc.) by determining their formality (non-established or } \\
\text { established interactions, interactions with regular cross-scale/within- } \\
\text { scale exchange) as well as organizational structures of the actor groups } \\
\text { (formally, informally, or not organized actor groups) and their } \\
\text { relevance for cross- or within-scale interconnections. }\end{array}$ & $\begin{array}{l}\text { Qualitative recording on (1) the organizational structure (formal or } \\
\text { informal) and (2) whether actor groups are actively in regular contact, and } \\
\text { exchange goods (wood, string instrument bows) or services (implementation } \\
\text { of conservation and plantation activities by local environmental NGOs on } \\
\text { behalf of musicians, violin and bow makers). Only the existence of these } \\
\text { interconnections was recorded, not their degree of intensity. }\end{array}$ \\
\hline
\end{tabular}

to only 49,727 trees during that century (Rocha 2008), which released pressure on the reduced pau-brasil populations (key ecological system variable, Table 4-S7). This was due to the discovery of organic synthetic dyes (aniline colors) (trigger T3, Table 4-T3; Fig. 4-T3) in 1856, which induced first an alternative system state, and then around 1900, a regime shift of the PB-CES to "the deceptive calm and a flourishing of bow making" upon the complete replacement of natural dyes (Michaelson 1993).

\section{The deceptive calm and flourishing of bow making ( 1900 to} 1998)

Selective cutting of pau-brasil from natural forests addressed the European wood demand by bow makers, but during the two World Wars, European-wide trade was heavily reduced. Expanding urbanization along the Brazilian coast triggered additional severe loss and degradation of the Mata Atlântica (Freitas et al. 2010). Since 1951, a company specializing in precious wood exportation in Guarana, Espírito Santo, has been dominating the trade of pau-brasil wood for string instrument bows. The company, providing wood and bows to the international market, ensured income for local community members, who worked as woodcutters and later, after the expansion to a local bow factory, as its employees. In 1978, paubrasil was declared Brazil's national tree due to its historical and emblematic importance for the country (Fig. 1, CES-A, key ecological element, relational value) (Dapson and Bain 2015). In the late 20th century, low-cost, low-quality Chinese mass production of carbon fiber bows (Table 4-D8) for non- professionals replaced the low-cost bows made of the Brazilian Manilkara bidentata, which put increasing pressure on traditional bow makers (Table 4-S9) (Moro 2019) but not on pau-brasil populations. However, vast devastated forest areas, ongoing exploitation of the Mata Atlântica as already described, and thus severe losses of pau-brasil populations led to the national listing of pau-brasil as an endangered species in 1992 (IBAMA 1992, revised 2013). By 1998, pau-brasil was included on the IUCN Red List as an endangered species (trigger T4; Fig. 1, exogenous control; Table 4-T4; Fig. 4-T4) (Varty 1998).

Control of the pau-brasillbow-making cultural-ecological system by intergovernmental protection and trade regulations (1998 to present day)

The inclusion of pau-brasil on Red Lists was absolutely necessary from a conservation perspective; however, this has caused a crisis (regime shift) for traditional bow makers, whose livelihoods depend on pau-brasil wood. Red Lists guide international trade regulations. Consequently, in 2000, highly concerned bow makers formed the NGO International Pernambuco Conservation Initiative (IPCI) in Paris (Table 4-F10) with multiple objectives: to foster the conservation of pau-brasil, and to implement paubrasil plantation projects for future commercial use and thereby prevent its listing in CITES. Until today, however, wood quality of planted trees compared to high-quality wood from trees in natural habitats has been seriously questioned, as have ambiguous regulations for their commercial use. Since unregulated trade could not be halted, pau-brasil made it into CITES's Appendix 
Fig. 4. Historical trajectory, evolution, and 1st, 2nd, 3rd, 4th, and 5th regimes of the pau-brasil/bow-making cultural-ecological system (PB-CES), considering 550 years within the organizational scales of the CES, including the global scale, the Mata Atlântica (Fig. 1, CES-A), and Europe (Fig. 1, CES-B), considering key system dimensions: (1) classical music, (2) violin and bow making, (3) natural environment, and (4) socio-political and economic contexts. X-axis: timeline of the development/evolution of the key dimensions, starting with the end of the 15th century, before the colonialization of Brazil in 1500 (T1). The use of the pau-brasil for bow making (T2) establishes the cultural-ecological system (gray background) that is the subject of our in-depth scientific analysis. With the invention of aniline dyes (T3), the use of pau-brasil for dye production lost considerable importance. Despite the resulting reduction in logging for dye extraction, the pau-brasil is on the verge of extinction due to progressive land use intensification and associated forest losses in the Atlantic Forest (extinction phase). The inclusion of pau-brasil on the IUCN Red List (T4) falls into the regeneration phase of pau-brasil populations, which then also entails international trade restrictions with the CITES listing (T5).

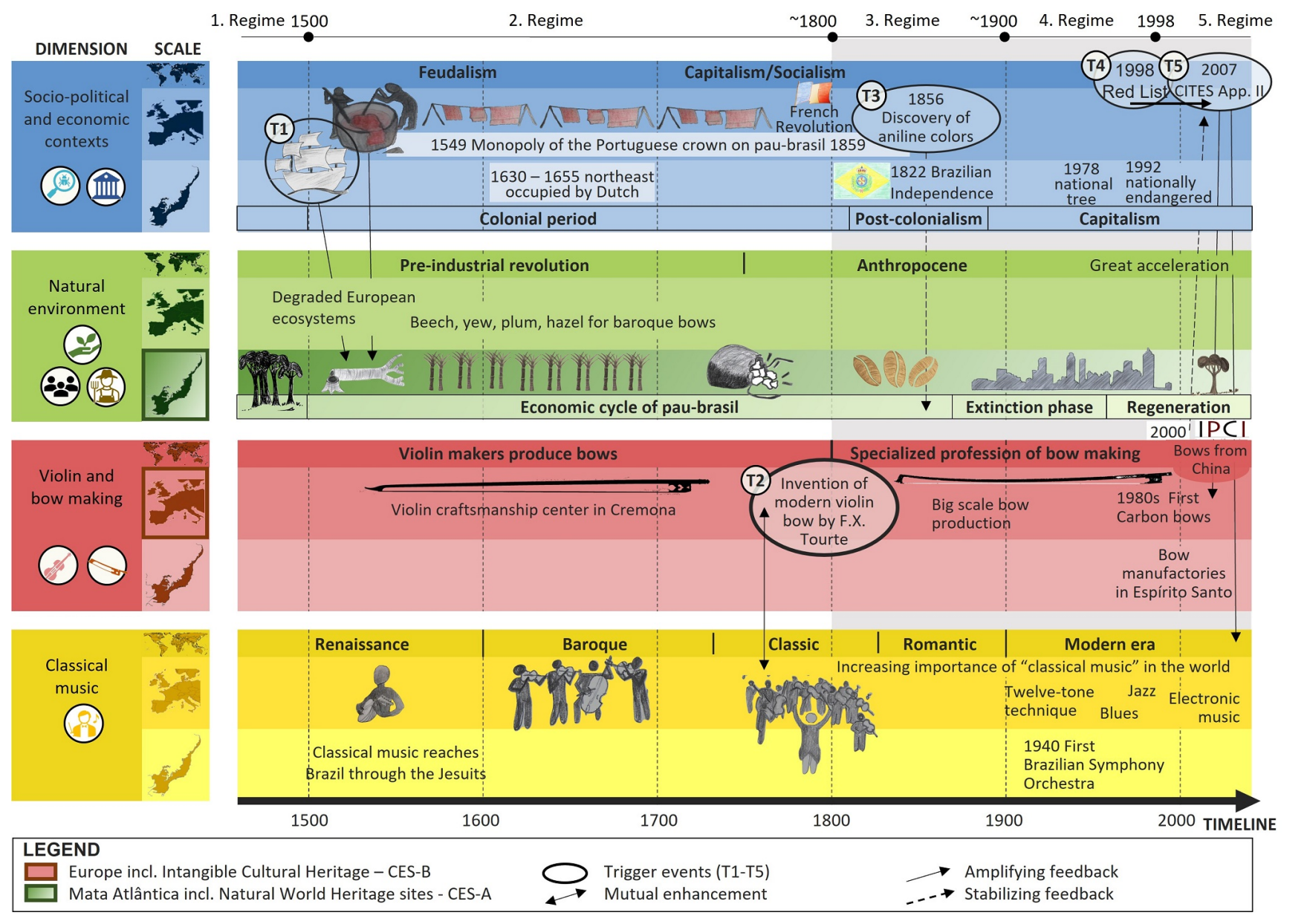

II in 2007 (trigger T5; Fig. 4-T5, exogenous control; Table 4-T5), yet the IPCI, musicians, and instrument makers managed to make finished string instrument bows exempt (CITES 2007, Waleson 2007). Since then, commercial trade has been requiring authorization for pau-brasil wood by the exporting and importing country. This induced drastic changes in the PB-CES, driven by strict ecological conservation mechanisms.

Cross-scale social relations and power relations among key actors of the pau-brasil/bow-making cultural-ecological system

Pau-brasil (Fig. 1, key ecological element of CES-A) provides 10 NCPs and ecosystem services with clear benefits for 11 current actor groups, eight of which are key actor groups of the PB-CES (Fig. 5; Table A6.1). For Brazilians, identity and sense-of-place are crucial non-material NCPs connected to pau-brasil, while in Europe, pau-brasil wood is a material $\mathrm{NCP} /$ provisioning-cultural service and thus key for bow-making craftsmanship (Fig. 1, key cultural element of CES-B) and human well-being. Pau-brasil is a cultural keystone species (see definition in Table A1.1) by virtue of its multifunctional local and distant cultural roles and irreplaceable functions in providing material, and especially for maintaining the system's integrity as predominant non-material NCPs/ESs (Fig. 5) within the PB-CES in the Mata Atlântica of Brazil (Fig. 1, CES-A) and in Europe (Fig. 1, CES-B). The key actor groups that depend directly on one or more of the identified NCPs/ESs (Fig. 1, key actor groups linked to the key cultural elements in CES-A, CES-B, and globally; Fig. 6; Table A6.2) are all institutionalized and formally organized at the European (Fig. 
Table 4. Chronological analysis of the pau-brasil/bow-making cultural-ecological system (PB-CES) considering (1) key trigger events (T1-T5), (2) drivers (D1-D12), (3) key system variables (S1-S15) of cultural or ecological relevance (C or E), and (4) feedback effects (F1-F13) ecologically stabilizing (E-S)/amplifying (E-A) on pau-brasil and/or culturally stabilizing (C-S)/amplifying (C-A) feedback effects on string instrument bow making at the three spatial scales: Mata Atlântica ([MA] Fig. 1, CES-A), (ii) Europe ([EUR] Fig. 1, CES-B), and global.

\begin{tabular}{|c|c|c|c|}
\hline Key triggers & Drivers & Changes in key system variables (S) & Stabilizing/amplifying feedback (S/A) \\
\hline \multicolumn{4}{|c|}{ 1st regime (before 1500): Pre-colonial ecocultural system in the Mata Atlântica and social-ecological systems within Europe } \\
\hline- & - & & $\begin{array}{l}\text { F1 (E-S): Sustainable land use by Tupi and } \\
\text { Guarani tribes (Nehren 2011) }\end{array}$ \\
\hline- & $\begin{array}{l}\text { D1: General European interest in natural } \\
\text { resources (exploitation) and expansion of } \\
\text { colonies (Dean 1996) }\end{array}$ & $\begin{array}{l}\text { S1 (E): Degradation of forests and } \\
\text { ecosystems in Europe (Moore 2002) }\end{array}$ & $\begin{array}{l}\text { F2 (E-A): Feudalism caused exploitation, } \\
\text { fostering soil-exhausting agriculture } \\
\text { (Moore 2002) }\end{array}$ \\
\hline
\end{tabular}

2nd regime (1500 to 1800 ): Pau-brasil exploitation for dyes

T1: 1500 Conquest and colonization of Brazil (MA social-ecological system; Fig. 1, CES-A from 1800 onward)
D2: High demand for red dye in Europe, and excessive wood extraction of pau-brasil (material nature's contributions to people/ provisioning service) for its red colorant, and land cover changes in Mata Atlântica (colonial exploitation cycles) (Dean 1996)

D3: At the end of the 18th century, concerts and classical music (cultural expression) became open to the general public; this implied larger audiences, who required large concert halls and opera houses
S2 (E): Drastic decline in and fragmentation of pau-brasil populations
F3 (E-A): European/Portuguese access to pau-brasil opened a new European market for its dye

S3 (C): Rise of violin-making craftsmanship tradition (cultural practice) and music being played with string instruments (cultural expression)

\section{S4 (C): Increasing technical} requirements in classical music (cultura expression), such as compositions,

became more virtuous and technically demanding, and increasing acoustical requirements for instrument making (larger concert halls require instruments with better sound propagation)
F4 (C-S): Availability of tropical wood species (material value, provisioningcultural services) enabled their use in the construction of European musical instruments, including bows for string instruments

F5 (C-S): Adaptation of musical instruments (Fig. 1, CES-B cultural practices) to increasing acoustical requirements through experimentation in bow shape (Fig. 1, CES-B cultural goods) and material use associated with a mutual enhancement between music and musical instrument making

3rd regime ( 1800 to $\sim 1900)$ : The invention of the "modern violin bow" gives rise to the telecoupled PB-CES

T2: 1800 Invention of "modern D4: High demand for pau-brasil wood violin bow" model (EUR; Fig. 1, (material nature's contributions to people/ CES-B, key cultural element)

T3: 1856 Discovery of aniline colors (EUR, Fig. 1, CES-B) provision service) for red dyes and increasingly for string instrument bows (Fig. 1, CES-A key ecological element, material value, provisioning-cultural service), though the demand was considerably less than for red dyes

D5: Increasing demand for and dependence on pau-brasil for "modern violin bows" (Fig. 1, CES-B, key cultural element, cultural good) adapted to the "new" requirements in playing classical music (Fig. 1, CES-B, key cultural element, cultural expression)

D6: Decreasing interest in pau-brasil (provisioning service) for red dyes (gradual decline to zero demand by the end of 20 th century)

4th regime (1900 to 1998): The deceptive calm and flourishing of bow making

D7: Music played with string instruments spread increasingly around the world (EUR; Fig. 1, CES-B, key cultural element, cultural expression)

D8: Increasing number of low-cost carbon fiber bows produced in China entered the European market
S5 (E): Continuous decline of pau-brasi populations and fragmentation of Mata Atlântica

S6 (E): Gradual change from baroque bows to the standardized model of modern bows made with pau-brasil, and the emergence of bow-making craftsmanship as a separate profession (Fig. 1, CES-B, key cultural element, cultural practices)

S7 (E): Decreasing pressure on paubrasil populations (quantitatively, the demand for bow wood was by far less than that for dyes); however, increasing land use changes triggered decline

S8 (C): Increasing number of bow makers in Europe maintained the traditional knowledge (Fig. 1, CES-B, key cultural element, cultural practices) S9 (C): Increased pressure on European bow makers caused by reduced production of low-cost bows made from Manilkara bidentata due to increased low-cost carbon bows
F6 (E-A): Selective extraction of paubrasil in the Mata Atlântica (Fig. 1, CESA, material value, provisioning-cultural service) also for making string instrument bows (Fig.1, CES-B, key cultural element, cultural practices)

F7 (C-S): Stepwise establishment of a market for the "modern violin bow" as the new standard bow model (Fig. 1, CES-B, key cultural element, cultural good)

F8 (E-S): Decreasing natural dye market in Europe and stepwise replacement by synthetic dyes

F9 (C-S): Increasing global market for string instrument bows, whose production was predominantly in Europe 
5th regime (1998 to present day): Control of the PB-CES by intergovernmental protection and trade regulations

T4: Listing of pau-brasil as an endangered species in the IUCN Red List in 1998 (global)
D9: Immediate risk of pau-brasil also being an endangered species in national and international Red Lists, with detrimental consequences for bow-making craftsmanship and classical music (Fig. 1, CES-B, key cultural elements) listed in CITES after having been included as

S10 (E): Globally recognized protection status of pau-brasil populations

S11 (C): Emerging awareness within the bow-making craftsmanship tradition of the situation of pau-brasil, and cooperation with Brazilian bow manufactures efforts of pau-brasil in the Mata Atlântica,

T5: Pau-brasil in CITES D11: Implementation of international trade Appendix II'in 2007, (global, Fig. regulations (global, Fig. 1, exogenous 1 , exogenous control)
D10: Important conservation/plantation financed by IPCI; e.g., within cocoa plantations in Bahia

S12 (E): Increasing number of paubrasil plantations reduced the pressure on native pau-brasil populations

S13 (E): In parts of Mata Atlântica, regeneration of pau-brasil populations due to strict protection of its populations

S14 (E): In parts of the Mata Atlântica,
pau-brasil populations continue to be

D12: Continuous wood demand for paubrasil for string instrument bows led to illegal pau-brasil exploitation and illegal trade under pressure because of illegal loggin
D13: Continuation of pau-brasil conservation and plantation projects in the Mata Atlântica financed by the IPCI
S15 (E): Regeneration of natural paubrasil populations due to national and international regulations in force
F10 (E-S): Bow makers as the most affected actor group found by the International Pernambuco Conservation Initiative (IPCI) in 2000. High credibility of IPCI and international musicians for lobbying at the CITES pre-meetings in 2007 , to exclude completed bows from regulation

F11 (C-A): Vast administrative effort to register pau-brasil stocks and prepare documents on the origin of material for internationally traveling musicians (Zauer and Pfriem 2018)

F12 (E-A): Intransparent pau-brasil wood trade in the global, Brazilian, and European markets (global illegal trade data are not available, leading to a missing transparency of the degree of illegal trade), misleading conclusions regarding the ratio of legal/illegal trade

F13 (C-A): Uncertainty about pau-brasil wood availability and quality in the future

\#10 logs, sawn wood, veneer sheets, including unfinished wood articles used for the fabrication of bows for stringed musical instruments

1, CES-B) and global scales. Only in the Mata Atlântica (Fig. 1, CES-A), violin and bow makers, musicians, and residents are not institutionalized or organized, which explains their small influence on the management of the NCPs/ESs of the pau-brasil tree (Fig. 6). Traditional bow makers are a numerically small actor group (worldwide >200) (Pfeifer 2002, Rymer 2004), whose livelihoods are mostly dependent on the pau-brasil tree (Level 3; Fig. 7). At the same time, they can be declared a "keystone" actor group that preserves traditional bow-making craftsmanship. Most farmers/plantation owners and residents of the Mata Atlântica (Fig. 1, CES-A) appear to be unaware of their direct and indirect dependencies on the NCPs/ESs of pau-brasil for their well-being (Level2, Fig. 7). Policy-makers show low dependencies at all scales (Level 1, Fig. 7), but exhibit the highest levels of influence, especially internationally and in the Mata Atlântica region (Level 3; Fig. 7). They are responsible for far-reaching legislative decisions, such as the CITES listing, laws regarding pau-brasil, and the UNESCO listings (see legal framework Table A6.4).

Cross-scale interconnections improve the level of influence for certain actor groups. For example, bow makers, musicians, and violin makers increased their level of influence (e.g., triggering the exclusion of finished bows from the CITES regulations in 2007) by strengthening the interconnections between existing formal associations (e.g., Entente Internationale des Maîtres Luthiers et Archetiers d'Art and European associations of these professions) and by founding new associations that focus on endangered species used for musical instruments (IPCI in 2000, and the International Alliance of Violin and Bow Makers for Endangered Species in 2018).

The complete dependence of bow makers on a single endangered species, coupled with their limited-to-moderate level of influence on (i) decision-making regarding the management of the NCPs/ ESs of pau-brasil, and consequently (ii) accessibility to highquality wood makes them the most disadvantaged actor group in this PB-CES at all scales (Mata Atlântica, Fig. 1, CES-A, Europe, Fig. 1, CES-B, international) (Fig. 7). Awakening the interest of the "oblivious" yet dependent actor groups in the Mata Atlântica (Fig. 1, CES-A) (farmers, plantation owners, Mata Atlântica residents) and increasing their stake in the PB-CES might be one step forward to overcoming historical patterns of exploitation and inequality, and toward a sustainable, participatory, and equitable transformation process. Therefore, striving for equal access to the NCPs/ESs of pau-brasil and for participatory decision-making processes will be crucial for long-term sustainable conservation strategies to preserve the natural and cultural heritage elements.

\section{DISCUSSION}

Cultural-ecological systems elucidate the important role of culture resulting from and shaped by peoples' values and appreciation of nature and culture within social-ecological systems, in this case, the pau-brasil/bow-making culturalecological system. Considering all elements of a social-ecological system, our framework (Fig. 1) presents a novel opportunity to analytically link and potentially protect nature, art, and culture, 
Fig. 5. Nature's contributions to people/ecosystem services (NCPs/ESs) of pau-brasil for different actors, including our key actor groups from the four dimensions of the pau-brasil/bow-making cultural-ecological system (PB-CES). The NCPs/ESs with a plain background are material NCPs/provisioning services, and in the case of the wood used for string instrument bows, it is a provisioning-cultural ecosystem service (dashed line). The services with plaid backgrounds are non-material NCPs/cultural ecosystem services. The actors in the table are assigned to the key thematic dimensions of our PB-CES, and the orbited actors are the key actor groups within the Mata Atlântica (MA) (Fig, 1, CES-A), Europe (Fig. 1, CES-B), and internationally. Residents and farmers/plantation owners occur only in the Mata Atlântica (Fig. 1, CES-A).

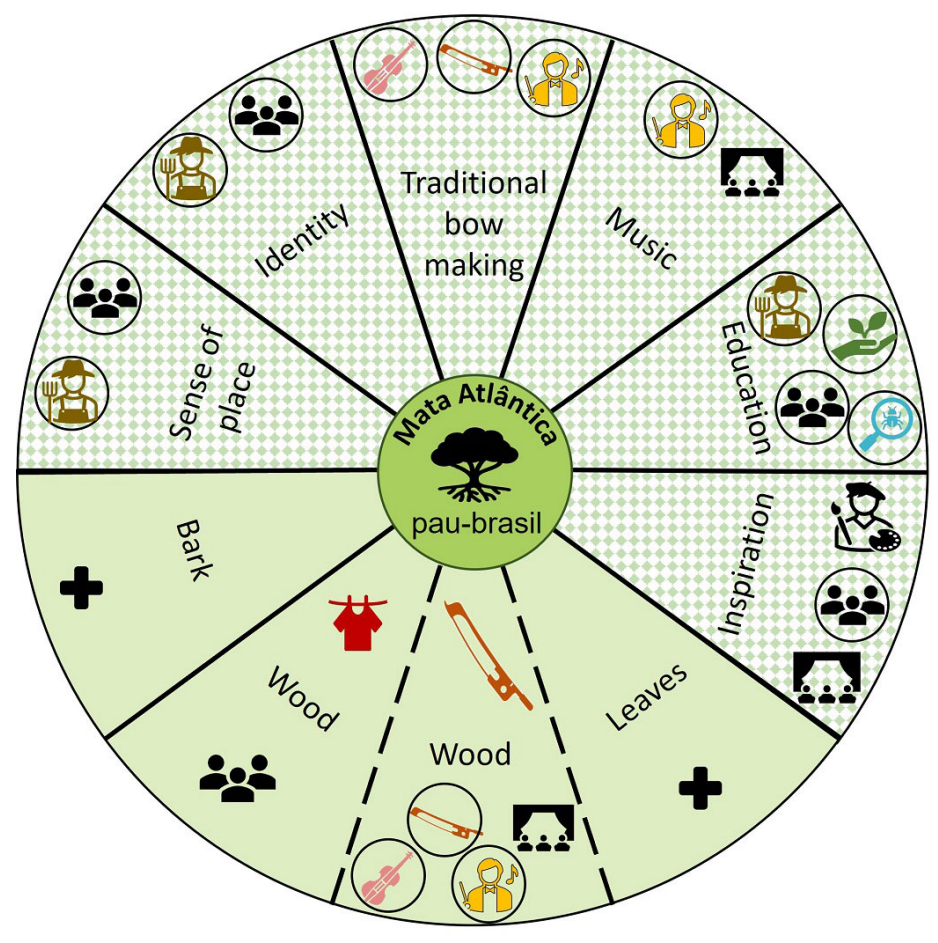

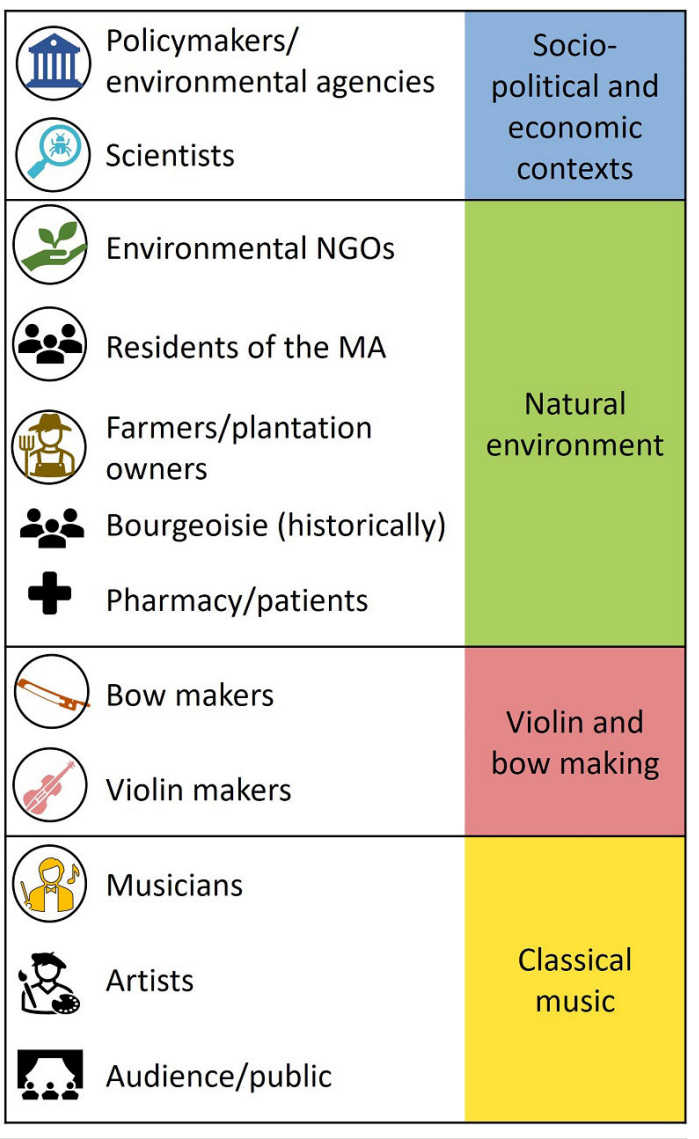

as well as natural and cultural heritage elements. Telecoupled cultural-ecological systems connect (i) distant geographic regions through telecoupling (Liu et al. 2013) and ultimately metacoupling (see definition in Table A1.1) (Liu 2017), and (ii) culturally relevant material and non-material NCPs/cultural ecosystem services (Chan et al. 2012, Fish et al. 2016) based on people's values of nature (Kenter 2018) that define "nature's contributions to people" (Pascual et al. 2017, Díaz et al. 2018) (Fig. 1) under the consideration of (iii) social and power relations of key actors that shape the coupledness of the system and the impacts on these NCPs/ESs. In a telecoupled cultural-ecological system approach, the focus is on culture, the specification and division of flows in culturally relevant NCPs/ESs and crosscontinental cultural exchanges and influences linked to key actor relationships that trace back to the underlying values of culture and nature (cultural causes) for people (Pascual et al. 2017). The value-based concept of NCPs/ESs includes intrinsic, and also importantly relational, and instrumental values, as proposed in our conceptual framework, which adds an urgently needed holistic scope to the NCP/ES concept (Christie et al. 2019) that highlights the role of relational values for sustainable societal and cultural transformations. In this regard, our process-oriented classification of cultural elements (cultural practice, cultural object/good, cultural expression) strongly supports this notion and allows for a clear understanding of the tightly interlinked tangible and intangible aspects of intangible cultural heritage and its five domains (UNESCO 2018): (a) oral traditions and expressions, including language as a vehicle of the intangible cultural heritage; (b) performing arts; (c) social practices, rituals, and festive events; (d) knowledge and practices concerning nature and the universe; and (e) traditional craftsmanship. In the search for pathways to produce sustainable string instrument bows, a metacoupling approach where a set of two or more coupled systems interact internally and with neighboring system(s) as well as with geographically distant systems (Liu 2017) could open new research potential. Cultural-ecological systems, such as our results for the telecoupled PB-CES, could be placed in a broader context; e.g., for the materials of musical instruments and their 
Fig. 6. Cross-scale influence-dependence framework (adapted from Martín-López et al. 2019) for the pau-brasil/bow-making cultural-ecological system (PB-CES), including the dependence of the key actor groups on pau-brasil and its nature's contributions to people/ecosystem services at three spatial scales (Mata Atlântica [Fig. 1, CES-A], Europe [Fig. 1, CES-B], international), and considering the cross-scale interconnections and influence levels on decision-making processes regarding the management of paubrasil and its ecosystem services by key actor groups at three spatial scales (Mata Atlântica [Fig. 1, CES-A], Europe [Fig. 1, CES-B], international). For the legend, see Fig. 5.

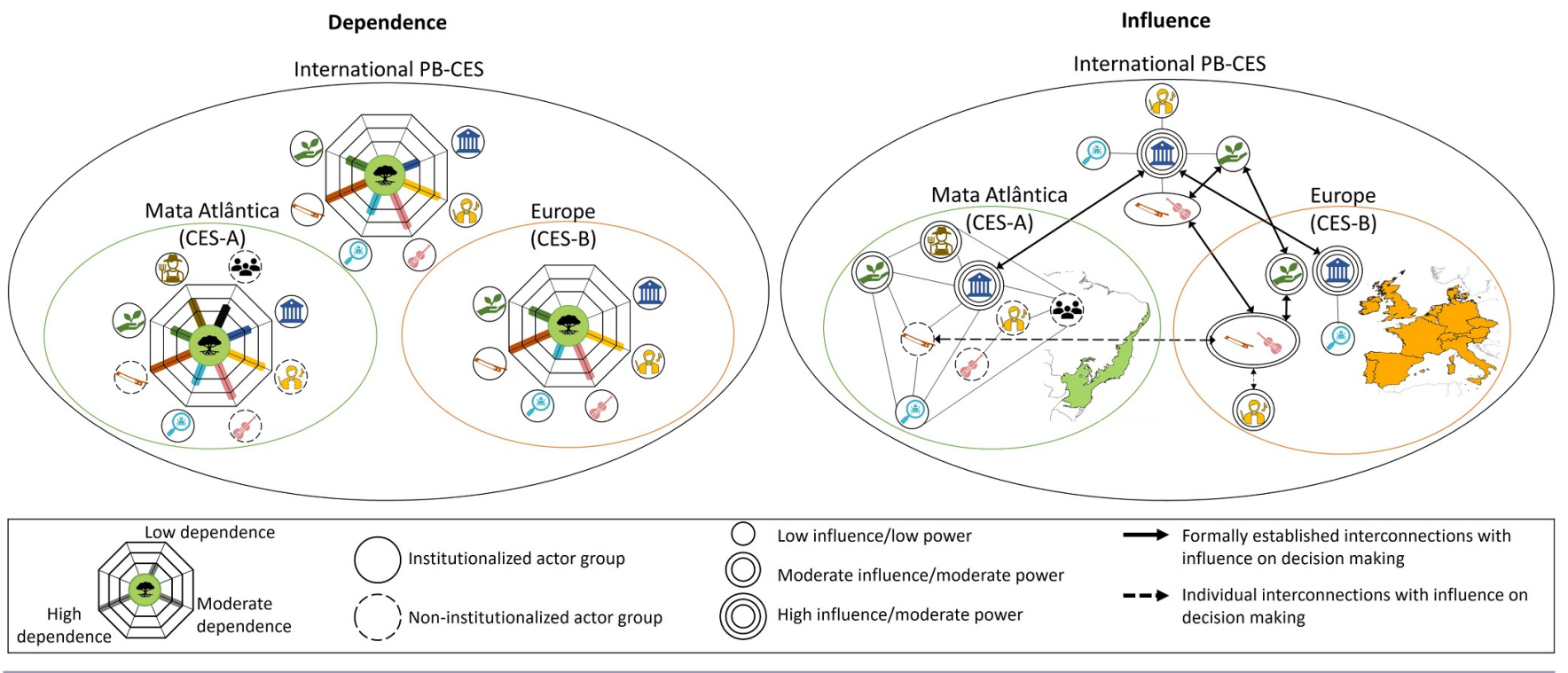

individual parts made from materials originating from a set of local, neighboring, and distant regions.

To gain an integrative perspective of system dynamics, Dearing et al. (2010) called for long-term observations (multidecadal or even multicentennial timescales) of coupled land systems (human-environment systems). Cultural-ecological systems with their focus on culture, art, traditions, and heritage, especially require such long-term analyses with a (tele)coupled perspective on land systems, land use, and particularly, land functions (Verburg et al. 2009). Our historical trajectory analysis shows that the invention of the "modern violin bow" was a key trigger event in the cultural dimension that induced a regime shift and gave rise to the PB-CES. It emerged from the increasing coupledness between environment and culture. However, around 1800, the European environment encompassed, in addition to the surrounding European ecosystem, the supply of exotic materials from geographically distant ecosystems, which suggests that globalization was already in full swing at that time (Nederveen Pieterse 2012). Therefore, incorporating and focusing on the role of material and non-material NCPs/cultural ecosystem services locally and especially across distant regions as well as on traditional knowledge and cultural needs, as mentioned by Colloff et al. (2020), is paramount to understanding system dynamics in order to create and find novel options for transformative adaptation and to prevent maladaptation. In this particular study, pau-brasil's delivery of diverse material and non-material NCPs makes it a cultural keystone species (Platten and Henfrey 2009) (definition in Table A1.1). Pau-brasil provides diverse cultural ecosystem services, and material and non-material NCPs (Fig. 5). Especially, its wood (material NCP/provisioning-cultural service) must undergo a complex production chain to unfold its full cultural service potential. First, it must be transformed by highly specialized traditional knowledge (intangible cultural heritage) so that another set of actor groups may then implement and develop (artistic) knowledge and skills (intangible cultural heritage) in order to generate the final cultural service performed by professionals (musicians, educators) in order for the end users to then experience non-material cultural benefits through listening to music (Fig. 1, cultural expression).

The cross-scale social actor analysis (Martín-López et al. 2019) bridges natural resource management (dependence-influence matrix) with ES research and political ecology (access and power relations, distributional and procedural equity) and thereby complements the telecoupling systems approach (Liu et al. 2013, Liu 2017) with inter-regional flows of goods and services (NCPs/ ESs). Our conceptual framework (Fig. 1) merges the approaches of Liu et al. (2013) and Martín-López et al. (2019) and provides a broad application for complex systems analysis, making it possible to explore the still unaccounted for, yet critically important linkages between natural and cultural heritage elements, ecosystems, and art through interconnected material and non-material NCPs/ESs that are key cultural and ecological elements of telecoupled cultural-ecological systems (e.g., African blackwood as an example of a key ecological element of a telecoupled cultural-ecological system [Table A2.1], a flagship species [Ball 2004] used in European woodwind instrumentmaking [example of a key cultural element of a telecoupled cultural-ecological system; Table A2.1] [Nakai et a1. 2019], and Tanzanian carving tradition [example of a key cultural element of a telecoupled cultural-ecological system; Table A2.1][Kingdon 
Fig. 7. Dependence-influence relations of key actor groups at three spatial scales (Mata Atlântica [Fig. 1, CES-A], Europe [Fig. 1, CES-B], international). The dependency levels are plotted on the X-axis; the influence levels are plotted on the Y-axis. The key actor group circled in bold is the most disadvantaged. For the legend, see Fig. 5.

\section{Dependence-influence matrices across scales}

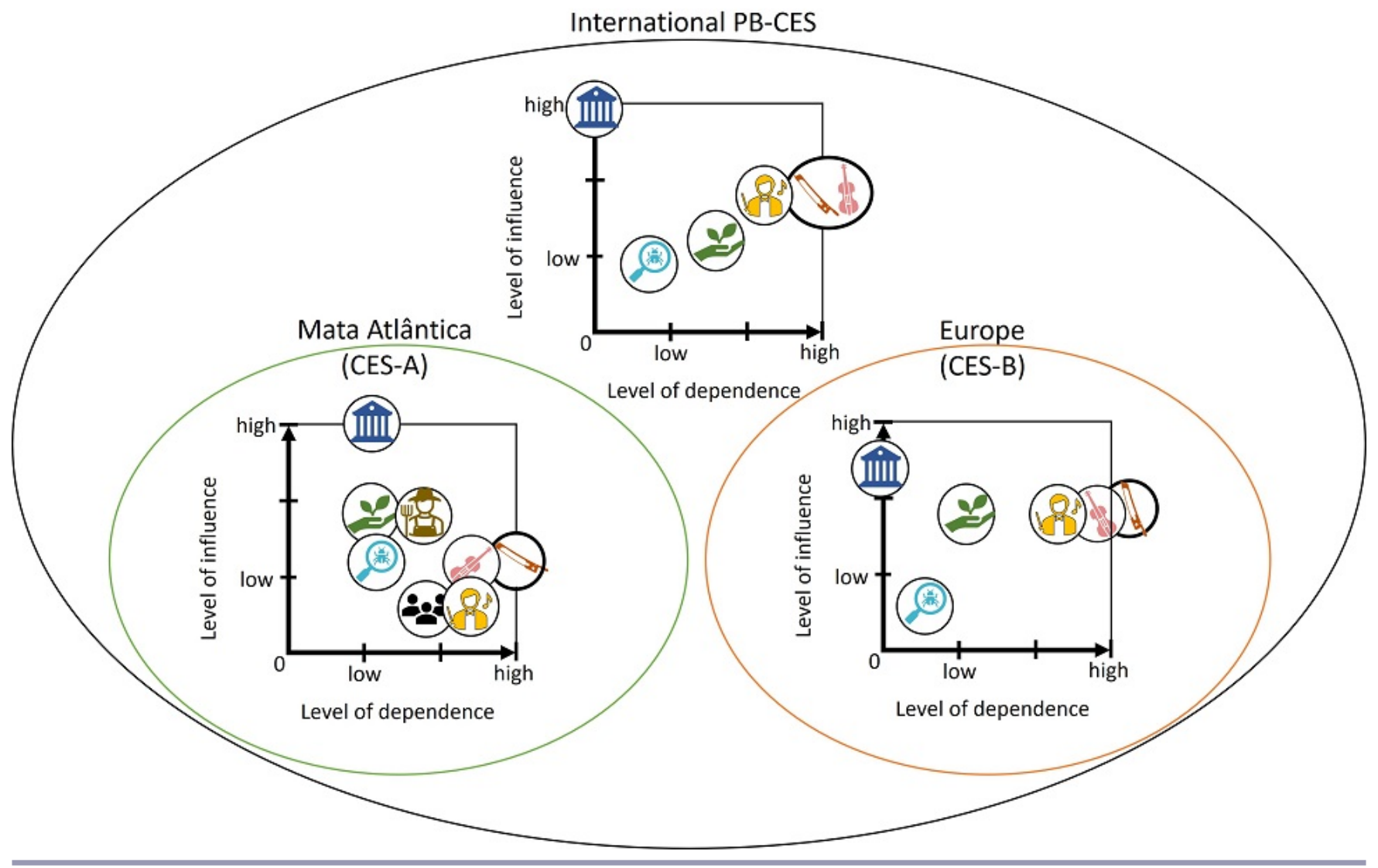

2005]). This novel approach implies the active inclusion and scrutiny of justice aspects of cultural-ecological systems and opens the perspective regarding their role in peace and a fair, just, and sustainably coexisting society. The longing for epistemic justice (Fricker 2013) and proper recognition of injustices both call for an epistemological break (Santos 2016). A suitable framework for future telecoupled cultural-ecological system analysis could be social-ecological justice, as defined by Gunnarsson-Östling and Svenfelt (2018), to support decisionmaking, policy, and planning. This goes beyond environmental justice by additionally considering local and distant environmental support systems (synonymous with local and distant ecosystem services and NCPs in general, in this study of the CES-A and CES-B) and incorporating intra- and intergenerational justice, visible and non-apparent dependence on ecosystems (here, material and non-material NCPs/provisioning, provisioning-cultural, and cultural services within the CES-A and CES-B), environmental benefits, and burdens (GunnarssonÖstling and Svenfelt 2018).

Music as a manifestation of culture and art is ephemeral and intangible in its interpretation and directly reliant on the practice and skills of the producer (Pinto 2014), potentially key actors of cultural-ecological systems. At the same time, music and musicians depend on musical instruments (Zhang 2012), which are often made of natural materials, especially wood. Compared to our approach, Wilson and Topham's (2004) research took a different perspective; they chose historical string instruments as a source of records and reference data for the history of European climate, and analyzed the instrument wood with dendrochronological methods. Ecological knowledge on growth conditions is fundamental in the selection of precious resonance wood, which is seminal for acoustically extraordinary musical instruments (Trifkovic 2016). By analyzing wood density and shrinkage range as quality indicators for pau-brasil wood, Marques et al. (2012) discovered that pau-brasil wood quality of wild and planted trees was similar. In contrast, Macedo et al. (2019) found that wild and planted pau-brasil trees exhibited different growth patterns. Finally, based on the wood analysis of historical French bows, a favorable place for good bow wood and plantations would be northeastern Brazil (Macedo et al. 2020). Further transdisciplinary and participatory research among agronomists; ecologists; environmental, forest, and wood scientists; bow makers; and musicians is urgently needed in order to clarify the specific environmental characteristics required to produce high-quality 
Table 5. Future trajectories of the pau-brasil/bow-making cultural-ecological system (MA = Mata Atlântica [Fig. 1, CES-A]; EUR = Europe [Fig. 1, CES-B])

\begin{tabular}{|c|c|c|c|}
\hline Scenario & System dynamics & Scale & Description \\
\hline \multirow[t]{7}{*}{ Optimistic win-win } & Telecoupled driver & $\begin{array}{l}\text { MA, } \\
\text { EUR }\end{array}$ & $\begin{array}{l}\text { Continuation of planting pau-brasil by the International Pernambuco Conservation } \\
\text { Initiative and local NGOs for commercial and conservation purposes }\end{array}$ \\
\hline & Long-term changes & MA & $\begin{array}{l}\text { (a) Establishment of new types of agricultural plantations (agroforestry), including pau- } \\
\text { brasil and other native tree species, (b) successful results regarding wood quality from } \\
\text { commercial plantations, (c) planting forests with pau-brasil trees as an alternative land use } \\
\text { to agriculture for farmers on a part of their land }\end{array}$ \\
\hline & & EUR & $\begin{array}{l}\text { Continuous use of pau-brasil from commercial plantations for high-quality string } \\
\text { instrument bows and increasing education for young bow-makers }\end{array}$ \\
\hline & & Global & $\begin{array}{l}\text { Reduction in the use of pau-brasil for low-cost, low-quality bows due to increasing } \\
\text { acceptance of carbon fiber bows by musicians in the course of quality improvement }\end{array}$ \\
\hline & Stabilizing feedback & MA & Recovery of natural pau-brasil populations in its natural habitat \\
\hline & & EUR & $\begin{array}{l}\text { Success of plantations leads to sufficient legal supply of sustainably produced wood for the } \\
\text { construction of high-quality bows, thereby maintaining the specialized and traditional } \\
\text { profession of crafting string bows }\end{array}$ \\
\hline & & Global & $\begin{array}{l}\text { Exclusive use of pau-brasil for the high-quality segment of bow making, therefore, in total, a } \\
\text { decreasing global demand }\end{array}$ \\
\hline \multirow[t]{5}{*}{ Pessimistic lose-win } & System variable & MA & $\begin{array}{l}\text { Continued destruction of the natural habitat of pau-brasil and selective illegal logging could } \\
\text { lead to a significant decline in the natural populations }\end{array}$ \\
\hline & Long-term changes & Global & $\begin{array}{l}\text { (a) Listing of pau-brasil in CITES Appendix I, (b) complete trade stop of pau-brasil, (c) } \\
\text { musicians, bow-makers, and violin-makers at an international level are probably reducing or } \\
\text { stopping their support for pau-brasil conservation and plantation }\end{array}$ \\
\hline & Stabilizing feedback & MA & Recovery of pau-brasil in its natural habitat (best case) \\
\hline & Amplifying feedback & EUR & Bow-makers could lose their livelihood, and the profession could disappear \\
\hline & & Global & $\begin{array}{l}\text { The listing could induce the collapse of the current pau-brasil/bow-making cultural- } \\
\text { ecological system. This collapse harbors opportunities and risks. In the best case, it could } \\
\text { lead to innovation and adaptation in bow making; in the worst case, it could have negative } \\
\text { effects on the profession of bow making and classical music. }\end{array}$ \\
\hline
\end{tabular}

resonance wood of pau-brasil for string instrument bows, and to examine under what environmental conditions wood from paubrasil plantations can compete with wood from virgin forests.

\section{Competing protection aims of natural and cultural heritage}

Generally, linking the protection of natural and cultural heritage is not a competition per se. For example, UNESCO considers the simultaneous local protection of natural and cultural heritage in the form of "cultural landscapes" (since 1992) and "mixed heritage" (Taylor and Lennon 2011). These concepts definitely do justice to the essential features of ecosystems and culture by not being strictly confined to administrative or political borders and recognizing place-based interconnections. However, linkages of both categories across geographically distinct regions lack recognition. Considering the relevance of the international network of violin makers to conserve the traditional knowledge of violin craftsmanship (Magnani 2014), we question whether the preservation can and should be geographically limited to Cremona, Italy. The results of our analysis suggest that UNESCO's existing frameworks and concepts need to evolve beyond their current understanding to do justice to the complexity of our globalized world by recognizing that an intangible cultural heritage may stand in an inseparable, telecoupled relationship with geographically distant natural resources and natural heritage elements. The introduction by UNESCO of a new category, "Telecoupled interwoven heritage", could strengthen the mutual appreciation and responsibility of the countries involved (here, European countries and Brazil with the Mata Atlântica) for the interdependent conservation of both kinds of heritage elements. This could qualify UNESCO to participate as an entirely new and independent body in the CITES conferences, and advise on the negotiation of trade regulations to equally conserve affected natural and intangible cultural heritage elements, thus transforming the current pathways for their perseverance. Such a holistic approach could pave the way for effective safeguarding strategies that consider the co-dependency of telecoupled cultural and natural heritage elements. With regard to musical instruments, our results are in line with those of Trifkovic (2016), who confirmed that by protecting natural forests, the production of high-quality resonance wood is guaranteed; this is an effective strategy to simultaneously sustain cultural and natural heritage elements.

\section{Possible future trajectories of the pau-brasil/bow-making cultural-ecological system}

In line with Dearing et al. (2010), we wish to highlight the importance of historical long-term analysis of the dynamics of coupled human-environment systems for anticipating future scenarios, considering land use change and cultural dynamics. Therefore, our transdisciplinary analysis, especially the historical trajectory of the PB-CES, provides a crucial basis for outlining two possible future trajectories for the PB-CES (Table 5, Fig. 8). Preserving the remaining pau-brasil populations while sustaining traditional bow-making craftsmanship could make it possible to maintain or enhance the cultural-ecological resilience of our PBCES (optimistic win-win scenario). This could be achieved by simultaneously increasing rehabilitation efforts in natural forests and restoration of secondary forests in protected areas that include pau-brasil populations. Other possible measures include planting pau-brasil in agroforestry systems and mixed-tree 
Fig. 8. Two possible future trajectories of the pau-brasil/bow-making cultural-ecological system (PB-CES): (A) an optimistic winwin scenario, where the occurrence of pau-brasil increases due to protection and/or reforestation and/or plantation efforts in the Mata Atlântica (Fig. 1, CES-A), which then helps maintain the profession of bow making in Europe (Fig. 1, CES-B) in the longterm; this may be enhanced by new education programs for young bow makers. (B) A pessimistic lose-win scenario, where increasingly stricter trade regulations will threaten traditional bow making in Europe (Fig. 1, CES-B) but protect the remaining fragments of the Mata Atlântica (Fig. 1, CES-A).

(A) Optimistic win-win scenario

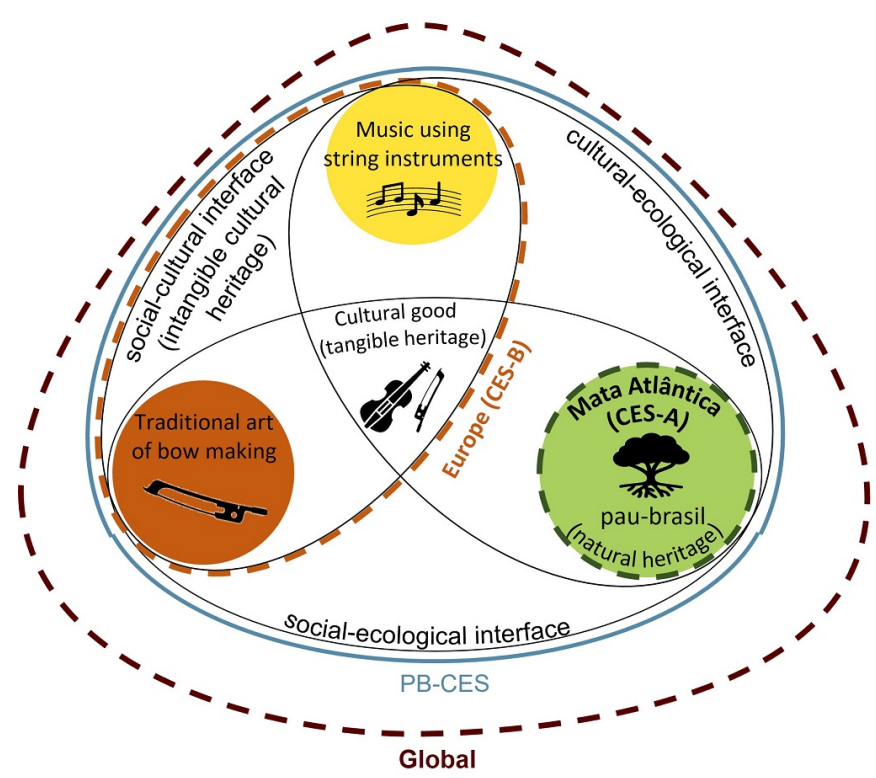

(B) Pessimistic lose-win scenario

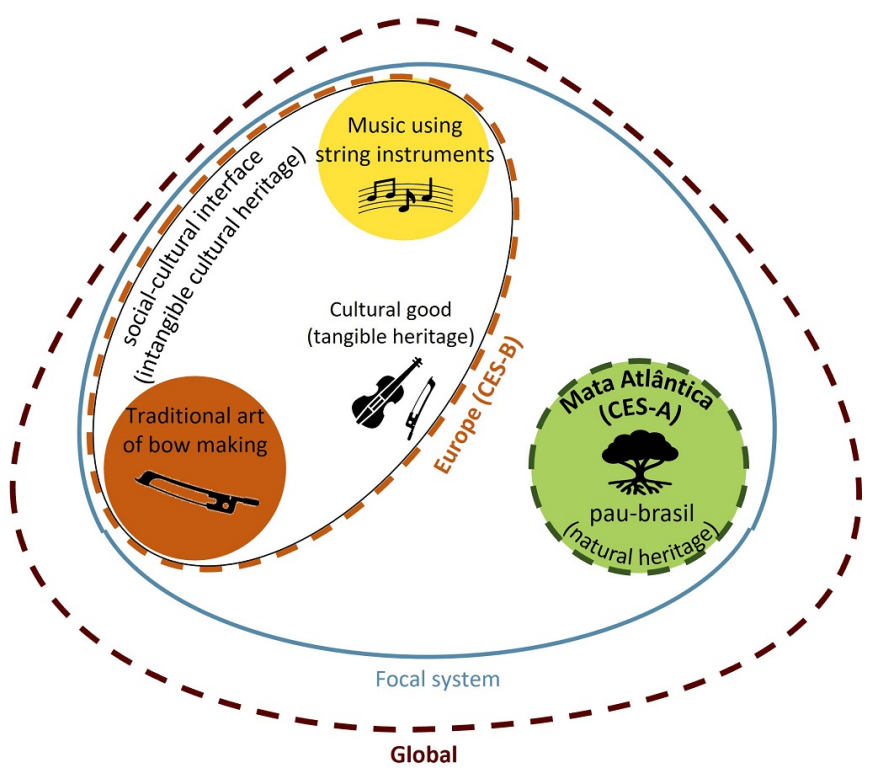

commercial plantations, taking into account local environmental legislation, legal registration procedures, and appropriate management plans (Lichtenberg et al. 2019).

The continuous search for ecologically compatible material alternatives, considering production, life cycle, and recycling aspects, as well as their improvement in physical and acoustical requirements, could be a complementary strategy to diversify material choices, thereby reducing the pressure on pau-brasil and increasing the resilience of the PB-CES. The use of alternative wood species could be another option, but without further restrictions, those species also risk becoming threatened (Bennett 2016), which has also been described as a process of "serial overexploitation" in the context of carving traditions (Cunningham et al. 2005). Certifications or supply chain laws that guarantee responsible and ecologically sustainable harvesting of wood for musical instruments and just and fair social trade standards appear to be crucial and inevitable for the preservation of the PB$\mathrm{CES}$ in the long term and in order to increase its resilience. From a cultural and living intangible cultural heritage perspective-i. e., the craftsmanship of string instrument bows - novel offers for bow-making apprenticeships are needed that incorporate both education on pau-brasil's ecological situation and its culturalecological role, and sustainable and responsible use of pau-brasil to support the education of young bow makers.

However, due to illegal trade, decimated pau-brasil populations, and a decreasing number of young bow makers, the current PBCES system regime is highly unstable, so there is concern that cultural-ecological tipping points may (soon) be crossed, causing an irreversible regime shift with unprecedented losses of key elements; e.g., the disappearance of bow-making craftsmanship, or the extinction of pau-brasil (pessimistic lose-win scenario). As stated by Huber-Sannwald et al. (2012), foreseeable crises and collapses require abilities to induce transformational processes that open opportunities for alternative long-term sustainable solutions (Walker and Meyers 2004, Folke et al. 2005). In the case of the PB-CES, this calls for innovative transformation, where changes in action and behavior prevent the crossing of any of the ecological, socio-cultural, or cultural-ecological tipping points.

\section{CONCLUSIONS}

Pau-brasil wood represents the linkage between the world natural heritage of the Mata Atlântica in Brazil and the intangible cultural heritage of traditional bow making in Europe. Availability of pau-brasil wood (provisioning services for dyes and provisioning cultural service for musical instruments) in Europe since the colonial age has significantly contributed to and shaped the cultural development of bow making and classical music. We have identified four key trigger events that led to transformations and hence regime shifts in this telecoupled PBCES: (1) the colonization of Brazil, (2) the invention of the modern violin bow made of pau-brasil, (3) the discovery of aniline colors in Europe, and (4) the inclusion of the pau-brasil species on the IUCN Red List and subsequently in Appendix II of CITES.

The cross-scale social actor analysis reveals strong dependencies on pau-brasil's ecosystem services within the PB-CES. Bow 
makers are the most resource-dependent and disadvantaged key actors, showing a high level of involvement in current conservation and plantation efforts, although most of them live outside Brazil. At the same time, selective illegal logging of paubrasil trees for bow making still occurs. Local NGOs are the most important partners for the implementation of plantations for the protection and possible future commercial use of pau-brasil. Potential threats to pau-brasil include illegal logging, trade, and forest loss. The main threat for traditional bow makers in Europe is the potential future listing of pau-brasil in Appendix I of CITES and the resulting trade restrictions. This analysis did not include the final "consumers" or end users of pau-brasil: concert audiences. Their perception, knowledge, opinion, and potential interest regarding pau-brasil and violin bows may become an additional unaccounted-for driver toward a sustainable development of the PB-CES. Our novel conceptual framework of telecoupled cultural-ecological systems and applied analysis have proven insightful for understanding a complex culturalecological system. Further applications and research on telecoupled cultural-ecological systems and the proposed conceptual framework can examine and broaden their applicability and stimulate new transdisciplinary research fields. Their application may serve as a transdisciplinary decisionmaking tool to increase the sustainable use of pau-brasil for string instrument bows. Transdisciplinary research approaches are urgently needed in order to tackle complex problems; they open new possibilities for multidimensional understanding and communication beyond academic disciplines, nature, and art.

Responses to this article can be read online at: https://www.ecologyandsociety.org/issues/responses. $\mathrm{php} / 13047$

\section{Acknowledgments:}

We gratefully thank the Heinrich-Böll-Stiftung for the dissertation grant that enabled this study, as well as the Mexican National Council for Science and Technology (CONACYT) and the DAAD for their support. A special thanks goes to Jakob Kusnick and Svenja Lichtenberg for their critical feedback and contribution to the figures of the article. Additionally, we would also like to thank the reviewers for their constructive feedback, which significantly improved our manuscript.

\section{Data Availability:}

Our research was conducted in accordance with the "Guidelines for Safeguarding Good Research Practice" of the German Research Foundation. None of the data of our research participants (respondents) is publicly accessible in order to fully protect their privacy; in addition, the answers of the survey were kept anonymous to protect the identity of the respondents and keep individual answers confidential. Interview-based data that support the results of this study are available to the editors upon request from Silke Lichtenberg (SL).

\section{LITERATURE CITED}

Abualhagag, A., and I. Valánszki. 2020. Mapping indicators of cultural ecosystem services: review and relevance to urban context. Journal of Landscape Ecology 13(1):4-24. https://doi. org/10.2478/jlecol-2020-0001

Aguiar, F. F., and R. A. Pinho. 2007. Pau-brasil: Caesalpinia echinata Lam., Árvore nacional. Instituto de Botânica, São Paulo, Brazil.

Alves, E. S., E. L. Longui, and E. Amano. 2008. Pernambuco wood (Caesalpinia echinata) used in the manufacture of bows for string instruments. IAWA Journal 29(3):323-335. https://doi. org/10.1163/22941932-90000190

Baines, A. 1961. Musical instruments through the ages. First edition. Penguin Books, London, UK.

Ball, S. M. J. 2004. Stocks and exploitation of East African blackwood Dalbergia melanoxylon: a flagship species for Tanzania's Miombo woodlands? Oryx (38):1-7. https://doi. org/10.1017/S0030605304000493

Becker, H., and B. Geer. 1957. Participant observation and interviewing: a comparison. Human Organization 16(3):28-32. https://doi.org/10.17730/humo.16.3.k687822132323013

Bennett, B. C. 2016. The sound of trees: wood selection in guitars and other chordophones. Economic Botany 70(1):49-63. https:// doi.org/10.1007/s12231-016-9336-0

Brandt, P., A. Ernst, F. Gralla, C. Luederitz, D. J. Lang, J. Newig, F. Reinert, D. J. Abson, and H. von Wehrden. 2013. A review of transdisciplinary research in sustainability science. Ecological Economics 92:1-15. https://doi.org/10.1016/j.ecolecon.2013.04.008

Brémaud, I., and N. Poidevin. 2013. Approches culturelles et mecaniques dans le choix des bois en facture: cas des archets anciens/Cultural and mechanical approaches in the choice of woods in instrument making: the case of early bows. Pages 1-27 in M. Castellengo, and H. Genevois, editors. La musique et ses instruments. Editions Delatour France, Sampzon.

Bridgewater, P., and I. D. Rotherham. 2019. A critical perspective on the concept of biocultural diversity and its emerging role in nature and heritage conservation. People and Nature 1 (3):291-304. https://doi.org/10.1002/pan3.10040

Chan, K. M., T. Satterfield, and J. Goldstein. 2012. Rethinking ecosystem services to better address and navigate cultural values. Ecological Economics 74:8-18. https://doi.org/10.1016/j. ecolecon.2011.11.011

Christie, M., B. Martín-López, A. Church, E. Siwicka, P. Szymonczyk, and J. Mena Sauterel. 2019. Understanding the diversity of values of "Nature's contributions to people": insights from the IPBES Assessment of Europe and Central Asia. Sustainability Science 14(5):1267-1282. https://doi.org/10.1007/ s11625-019-00716-6

Coleman, J. 1958. Relational analysis: the study of social organizations with survey methods. Human Organization 17 (4):28-36. 10.17730/humo.17.4.q5604m676260q8n7

Colloff, M. J., R. M. Wise, I. Palomo, S. Lavorel, and U. Pascual. 2020. Nature's contribution to adaptation: insights from examples 
of the transformation of social-ecological systems. Ecosystems and People 16(1):137-150. https://doi.org/10.1080/26395916.2020.1754919

Convention on International Trade in Endangered Species of Wild Fauna and Flora (CITES). 2007. Consideration of Proposals for Amendment of Appendices I and II: Fourteenth Meeting of the Conference of the Parties, The Hague (Netherlands), 3-15 June 2007.

Cordero, D., and C. Mello. 2008. Caesalpinia echinata. Morton Arboretum (Cites 2007):1-10.

Cristancho, S., and J. Vining. 2004. Culturally defined keystone species. Human Ecology Review (11):153-164.

Cronquist, A. 1992. An integrated system of classification of flowering plants. [Repr.] Columbia University Press, New York, USA.

Cunningham, A., B. Campbell, B. M. Belcher, and R. Achdiawan. 2005. Ecological footprints: carving, sustainability and scarcity. Pages 199-228 in A. Cunningham, B. Campbell, and B. M. Belcher, editors. Carving out a future: forests, livelihoods and the international woodcarving trade. Earthscan, Sterling, Virginia, USA.

Dapson, R., and C. Bain. 2015. Brazilwood, sappanwood, brazilin and the red dye brazilein: from textile dyeing and folk medicine to biological staining and musical instruments. Biotechnic \& Histochemistry 90(6):401-423. https://doi. org/10.3109/10520295.2015.1021381

Dean, W. 1996. A ferro e fogo: A história e a devastação da mata atlântica brasileira. Sixth edition. Companhia das letras, São Paulo.

Dearing, J. A., A. K. Braimoh, A. Reenberg, B. L. Turner, and S. van der Leeuw. 2010. Complex land systems: the need for long time perspectives to assess their future. Ecology and Society 15 (4):21. https://doi.org/10.5751/ES-03645-150421

Díaz, S., U. Pascual, M. Stenseke, B. Martín-López, R. T. Watson, Z. Molnár, R. Hill, K. M. A. Chan, I. A. Baste, K. A. Brauman, S. Polasky, A. Church, M. Lonsdale, A. Larigauderie, P. W. Leadley, A. P. E. van Oudenhoven, F. van der Plaat, M. Schröter, S. Lavorel, Y. Aumeeruddy-Thomas, E. Bukvareva, K. Davies, S. Demissew, G. Erpul, P. Failler, C. A. Guerra, C. L. Hewitt, H. Keune, S. Lindley, and Y. Shirayama. 2018. Assessing nature's contributions to people. Science 359(6373):270-272. https://doi. org/10.1126/science.aap8826

Elsasser, P., G. Koch, and S. Björn. 2011. Eine Abschätzung der deutschen Importe an (Tropen-)Hölzern durch den Import von Musikinstrumenten. Institut für Ökonomie der Forst- und Holzwirtschaft, Hamburg, Germany.

Ferrari, R. 2015. Writing narrative style literature reviews. Medical Writing 24(4):230-235. https://doi.org/10.1179/2047480615Z.000000000329

Fish, R., A. Church, and M. Winter. 2016. Conceptualising cultural ecosystem services: a novel framework for research and critical engagement. Ecosystem Services 21:208-217. https://doi. org/10.1016/j.ecoser.2016.09.002
Folke, C., T. Hahn, P. Olsson, and J. Norberg. 2005. Adaptive governance of social-ecological systems. Annual Review of Environment and Resources 30(1):441-473. https://doi. org/10.1146/annurev.energy.30.050504.144511

Forzza, R. C., J. F. A. Baumgratz, C. E. M. Bicudo, D. A. L. Canhos, A. A. Carvalho, M. A. N. Coelho, A. F. Costa, D. P. Costa, M. G. Hopkins, P. M. Leitman, L. G. Lohmann, E. N. Lughadha, L. C. Maia, G. Martinelli, M. Menezes, M. P. Morim, A. L. Peixoto, J. R. Pirani, J. Prado, L. P. Queiroz, S. Souza, V. C. Souza, J. R. Stehmann, L. S. Sylvestre, B. M. T. Walter, and D. C. Zappi. 2012. New Brazilian floristic list highlights conservation challenges. BioScience 62(1):39-45. https://doi.org/10.1525/ bio.2012.62.1.8

Freitas, S. R., T. J. Hawbaker, and J. P. Metzger. 2010. Effects of roads, topography, and land use on forest cover dynamics in the Brazilian Atlantic Forest. Forest Ecology and Management 259 (3):410-417. https://doi.org/10.1016/j.foreco.2009.10.036

Fricker, M. 2013. Epistemic justice as a condition of political freedom? Synthese 190(7):1317-1332. https://doi.org/10.1007/ s11229-012-0227-3

Gagnon, E., A. Bruneau, C. E. Hughes, L. de Queiroz, and G. P. Lewis. 2016. A new generic system for the pantropical Caesalpinia group (Leguminosae). PhytoKeys 71:1-160. https://doi. org/10.3897/phytokeys.71.9203

Galindo-Leal, C., and I. d. G. Câmara, editors. 2005. Mata Atlântica: Biodiversidade, ameaças e perspectivas. Fundação SOS Mata Atlântica; Conservação Internacional, São Paulo, Belo Horizonte.

Garibaldi, A., and N. Turner. 2004. Cultural keystone species: implications for ecological conservation and restoration. Ecology and Society 9(3):1. https://doi.org/10.5751/ES-00669-090301

Gunnarsson-Östling, U., and ̊. Svenfelt. 2018. Sustainability discourses and justice: towards social-ecological justice. Pages 160-171 in R. Holifield, R. Holifield, J. Chakraborty, and G. Walker, editors. The Routledge handbook of environmental justice. Routledge Taylor \& Francis Group, London, UK. https:// doi.org/10.4324/9781315678986-14

Hanspach, J., L. Jamila Haider, E. Oteros-Rozas, A. Stahl Olafsson, N. M. Gulsrud, C. M. Raymond, M. Torralba, B. Martín-López, C. Bieling, M. García-Martín, C. Albert, T. H. Beery, N. Fagerholm, I. Díaz-Reviriego, A. Drews-Shambroom, and T. Plieninger. 2020. Biocultural approaches to sustainability: a systematic review of the scientific literature. People and Nature 2(3):643-659. https://doi.org/10.1002/pan3.10120

Heritage Crafts Association (HCA). 2021. Red List of Endangered Crafts. Somerset, UK. [online] URL: https:// heritagecrafts. org.uk/wp-content/uploads/2021/05/HCA-Red-List-2021leaflet-optimised.pdf

Huber-Sannwald, E., M. Ribeiro Palacios, J. T. Arredondo Moreno, M. Braasch, R. M. Martinez Pena, de Alba Verduzco, J. G., and K. Monzalvo Santos. 2012. Navigating challenges and opportunities of land degradation and sustainable livelihood development in dryland social-ecological systems: a case study from Mexico. Philosophical Transactions of the Royal Society B, 
Biological Sciences 367(1606):3158-3177. https://doi.org/10.1098/ rstb.2011.0349

Instituto Brasileiro de Geografia e Estatística (IBGE). 2006. Mapa da Área de Aplicação da Lei n ${ }^{\circ} 11.428$, de 2006. [online] URL: https://www.mma.gov.br/informma/item/271-mapa-da- $\%$ C3\%A1rea-de-aplica $\% \mathrm{C} 3 \% \mathrm{~A} 7 \% \mathrm{C} 3 \% \mathrm{~A} 30$

Instituto Brasileiro do Meio Ambiente e dos Recursos Naturais Renováveis (IBAMA). 1992. Portaria IBAMA Nº 37-N, de 3 de abril de 1992: Lista Oficial de Espécies da Flora Brasileira Ameaçadas de Extinção. [online] URL: https://licenciamento. cetesb.sp.gov.br/legislacao/federal/portarias/1992_Port_IBAMA_37. pdf

Kenter, J. O. 2018. IPBES: Don't throw out the baby whilst keeping the bathwater; Put people's values central, not nature's contributions. Ecosystem Services 33:40-43. https://doi. org/10.1016/j.ecoser.2018.08.002

Kingdon, Z. 2005. Sculpture and identity: the Makonde African blackwood carving movement. Pages 53-65 in A. Cunningham, B. Campbell, and B. M. Belcher, editors. Carving out a future: forests, livelihoods and the international woodcarving trade. Earthscan, Sterling, Virginia, USA.

Lichtenberg, S., E. Huber-Sannwald, U. Nehren, and J. A. ReyesAgüero. 2019. Use and conservation of the threatened Brazilian national tree Paubrasilia echinata Lam.: a potential for Rio de Janeiro State? Pages 205-219 in U. Nehren, S. Schlüter, C. Raedig, D. Sattler, and H. Hissa, editors. Strategies and tools for a sustainable rural Rio de Janeiro. Springer International Publishing, Cham. https://doi.org/10.1007/978-3-319-89644-1 14

Lindholm, K.-J., and A. Ekblom. 2019. A framework for exploring and managing biocultural heritage. Anthropocene 25:100195. https://doi.org/10.1016/j.ancene.2019.100195

Liu, J. 2017. Integration across a metacoupled world. Ecology and Society 22(4)29. https://doi.org/10.5751/ES-09830-220429

Liu, J., V. Hull, M. Batistella, R. DeFries, T. Dietz, F. Fu, T. W. Hertel, R. C. Izaurralde, E. F. Lambin, S. Li, L. A. Martinelli, W. J. McConnell, E. F. Moran, R. Naylor, Z. Ouyang, K. R. Polenske, A. Reenberg, G. de Miranda Rocha, C. S. Simmons, P. H. Verburg, P. M. Vitousek, F. Zhang, and C. Zhu. 2013. Framing sustainability in a telecoupled world. Ecology and Society 18 (2):26. http://dx.doi.org/10.5751/ES-05873-180226

Longui, E. L., D. R. Lombardi, and E. S. Alves. 2010. Potential Brazilian wood species for bows of string instruments. Holzforschung 64:511-520. https://doi.org/10.1515/hf.2010.068

Lowenthal, D. 2005. Natural and cultural heritage. International Journal of Heritage Studies 11(1):81-92. https://doi. org/10.1080/13527250500037088

Luck, G. W., R. Harrington, P. A. Harrison, C. Kremen, P. M. Berry, R. Bugter, T. P. Dawson, F. de Bello, S. Díaz, C. K. Feld, J. R. Haslett, D. Hering, A. Kontogianni, S. Lavorel, M. Rounsevell, M. J. Samways, L. Sandin, J. Settele, M. T. Sykes, S. van den Hove, M. Vandewalle, and M. Zobel. 2009. Quantifying the contribution of organisms to the provision of ecosystem services. BioScience 59(3):223-235.
Macedo, T. M., C. G. Costa, H. C. d. Lima, and C. F. Barros. 2020. Wood anatomy of historic French violin bows made of Pernambuco wood. IAWA Journal-1:1-13. https://doi. org/10.1163/22941932-bja10011

Macedo, T. M., H. C. d. Lima, N. D. de Souza, A. C. Gonçalves, C. G. Costa, and C. F. Barros. 2019. Intraspecific variation of Paubrasilia echinata (Fabaceae) wood along a latitudinal gradient in Brazil. Flora 258:151437. https://doi.org/10.1016/j.flora.2019.151437

Magnani, M. 2014. Creating economic growth. Palgrave Macmillan, London, UK. https://doi.org/10.1057/9781137427052

Marques, S. d. S., J. T. S. Da Oliveira, J. B. Paes, E. S. Alves, A. G. da Silva, and N. C. Fiedler. 2012. Estudo comparativo da massa específica aparente e retratibilidade da madeira de pau-brasil (Caesalpinia echinata Lam.) nativa e de reflorestamento. Revista Árvore 36(2):373-380. https://doi.org/10.1590/S0100-67622012000200019

Martinelli, G., and M. Moraes. 2013. Livro vermelho da flora do Brasil. Ecological Modelling.

Martín-López, B., M. R. Felipe-Lucia, E. M. Bennett, A. Norström, G. Peterson, T. Plieninger, C. C. Hicks, F. Turkelboom, M. García-Llorente, S. Jacobs, S. Lavorel, and B. Locatelli. 2019. A novel telecoupling framework to assess social relations across spatial scales for ecosystem services research. Journal of Environmental Management 241:251-263. https://doi.org/10.1016/ j.jenvman.2019.04.029

Matsunaga, M., and K. Minato. 1998. Physical and mechanical properties required for violin bow materials II: comparison of the processing properties and durability between pernambuco and substitutable wood species. Journal of Wood Science 44 (2):142-146. https://doi.org/10.1007/BF00526260

Merçon, J., S. Vetter, M. Tengö, M. Cocks, P. Balvanera, J. A. Rosell, and B. Ayala-Orozco. 2019. From local landscapes to international policy: contributions of the biocultural paradigm to global sustainability. Global Sustainability 2:54. https://doi. org/10.1017/sus.2019.4

Michaelson, J. C. 1993. Aniline in history and technology. Endeavour 17(3):121-126. https://doi.org/10.1016/0160-9327(93) 90101-8

Millennium Ecosystem Assessment (MEA). 2005. Ecosystems and human well-being: synthesis. Island Press, Washington, D. C., USA.

Montaigne, J.-M. 2000. Le trafiq du Brésil: Navigateurs normands, bois-rouge et cannibales pendant la Renaissance. ASI communication, Rouen.

Moore, J. W. 2002. The crisis of feudalism: an environmental history. Organization \& Environment 15(3):301-322. https://doi. org/10.1177/1086026602153008

Moro, P. A. 2019. Violins: local meanings, globalized sounds. Routledge, New York, New York, USA. https://doi. org/10.4324/9780429468292

Nakai, K., M. Ishizuka, S. Ohta, J. Timothy, M. Jasper, N. M. Lyatura, V. Shau, and T. Yoshimura. 2019. Environmental factors and wood qualities of African blackwood, Dalbergia 
melanoxylon, in Tanzanian Miombo natural forest. Journal of Wood Science 65(1). https://doi.org/10.1186/s10086-019-1818-0

Nederveen Pieterse, J. 2012. Periodizing globalization: histories of globalization. New Global Studies 6(2). https://doi. org/10.1515/1940-0004.1174

Nehren, U. 2011. Historische Landschaftsdegradation und aktuelle Nutzungsproblematik in der Serra dos Órgãos Rio de Janeiro. Pages 11-25 in M. Coy and M. Neuburger, editors. Global Change: Herausforderungen für Lateinamerika. Bd. 38. Innsbrucker Geographische Studien.

Nehren, U., A. Kirchner, D. Sattler, A. P. Turetta, and J. Heinrich. 2013. Impact of natural climate change and historical land use on landscape development in the Atlantic Forest of Rio de Janeiro, Brazil. Anais da Academia Brasileira de Ciências 85 (2):497-518. https://doi.org/10.1590/S0001-37652013000200004

Pascual, U., P. Balvanera, S. Díaz, G. Pataki, E. Roth, M. Stenseke, R. T. Watson, E. Başak Dessane, M. Islar, E. Kelemen, V. Maris, M. Quaas, S. M. Subramanian, H. Wittmer, A. Adlan, S. Ahn, Y. S. Al-Hafedh, E. Amankwah, S. T. Asah, P. Berry, A. Bilgin, S. J. Breslow, C. Bullock, D. Cáceres, H. Daly-Hassen, E. Figueroa, C. D. Golden, E. Gómez-Baggethun, D. GonzálezJiménez, J. Houdet, H. Keune, R. Kumar, K. Ma, P. H. May, A. Mead, P. O'Farrell, R. Pandit, W. Pengue, R. Pichis-Madruga, F. Popa, S. Preston, D. Pacheco-Balanza, H. Saarikoski, B. B. Strassburg, M. van den Belt, M. Verma, F. Wickson, and N. Yagi. 2017. Valuing nature's contributions to people: the IPBES approach. Current Opinion in Environmental Sustainability 26-27:7-16. https://doi.org/10.1016/j.cosust.2016.12.006

Pfeifer, E. 2002. Violin bows go high tech. (November 13, 2002). Wall Street Journal. [online] URL: https://www.spiccato.com/wpcontent/uploads/2020/10/Wall-Street-Journal-High-Tech-2002.pdf

Pinto, T. d. O. 2014. Musik, implizites Wissen und immaterielles Kulturerbe. Paragrana 23(2). https://doi.org/10.1515/para-2014-0220

Pinto, T. d. O. 2018. Music as intangible cultural heritage: the Southeast Asia Music Museum (SEAM), Bangkok, Thailand. In H-Soz-Kult, editor. Private passion ! public challenge: Musikinstrumente sammeln in Geschichte und Gegenwart (Nürnberg, 09.05.2017 - 11.05.2017). Verlag des Germanischen Nationalmuseums, Nürnberg.

Pires, A. P. F., M. C. G. Padgurschi, P. D. de Castro, F. R. Scarano, B. Strassburg, C. A. Joly, R. T. Watson, and R. de Groot. 2020. Ecosystem services or nature's contributions? Reasons behind different interpretations in Latin America. Ecosystem Services 42:101070. https://doi.org/10.1016/j.ecoser.2020.101070

Platten, S., and T. Henfrey. 2009. The cultural keystone concept: insights from ecological anthropology. Human Ecology 37 (4):491-500. https://doi.org/10.1007/s10745-009-9237-2

Rezende, C. L., F. R. Scarano, E. D. Assad, C. A. Joly, J. P. Metzger, B. Strassburg, M. Tabarelli, G. A. Fonseca, and R. A. Mittermeier. 2018. From hotspot to hopespot: an opportunity for the Brazilian Atlantic Forest. Perspectives in Ecology and Conservation 16(4):208-214. https://doi.org/10.1016/j.pecon.2018.10.002

Richards, J., S. A. Orr, and H. Viles. 2020. Reconceptualising the relationships between heritage and environment within an Earth
System Science framework. Journal of Cultural Heritage Management and Sustainable Development 10(2):122-129. https://doi.org/10.1108/JCHMSD-08-2019-0099

Rocha, Y. T. 2008. Parte I - História: 1. Brasil, Europeus e paubrasil. Pages 9-32 in Ribeiro, Rita de Cássia Leone Figueiredo, C. J. Barbedo, E. S. Alves, M. Domingos, and M. R. Braga, editors. Pau-brasil da semente à madeira. First edition. Instituto de Botânica/SMA, São Paulo, Brazil.

Rocha, Y. T., A. Presotto, and F. Cavalheiro. 2007. The representation of Caesalpinia echinata (Brazilwood) in sixteenthand-seventeenth-century maps. Anais da Academia Brasileira de Ciências 79(4):751-765. https://doi.org/10.1590/S0001-37652007000400014

Rymer, R. 2004. Saving the music tree: artists and instrument makers have banded together to rescue Brazil's imperiled pernambuco, the source of bows for violins, violas and cellos. Smithsonian Magazine, April.

Rymer, R. 2007. A fight for survival. The Strad June:28-32.

Santos, B. d. S. 2016. Epistemologies of the South: justice against epistemicide. First edition. Routledge, London, UK.

Schebeck. 1877. "Duiffopruggar, Gasparo": Duiffopruggar. Pages 454-455 in Allgemeine Deutsche Biographie.

Schimleck, L. R., C. Espey, C. R. Mora, R. Evans, A. Taylor, and G. Muniz. 2009. Characterization of the wood quality of pernambuco (Caesalpinia echinata Lam) by measurements of density, extractives content, microfibril angle, stiffness, color, and NIR spectroscopy. Holzforschung 63(4):457-463. https://doi. org/10.1515/HF.2009.082

Schirpke, U., C. Meisch, and U. Tappeiner. 2018. Symbolic species as a cultural ecosystem service in the European Alps: insights and open issues. Landscape Ecology 33(5):711-730. https://doi. org/10.1007/s10980-018-0628-X

Sprent, J. I., and R. Parsons. 2000. Nitrogen fixation in legume and non-legume trees. Field Crops Research 65(2-3):183-196. https://doi.org/10.1016/S0378-4290(99)00086-6

Sutherland, W. J., E. Fleishman, M. B. Mascia, J. Pretty, and M. A. Rudd. 2011. Methods for collaboratively identifying research priorities and emerging issues in science and policy. Methods in Ecology and Evolution 2(3):238-247. https://doi.org/10.1111/ j.2041-210X.2010.00083.X

Taylor, K., and J. Lennon. 2011. Cultural landscapes: a bridge between culture and nature? International Journal of Heritage Studies 17(6):537-554. https://doi.org/10.1080/13527258.2011.618246

Tengö, M., E. S. Brondizio, T. Elmqvist, P. Malmer, and M. Spierenburg. 2014. Connecting diverse knowledge systems for enhanced ecosystem governance: the multiple evidence base approach. AMBIO 43(5):579-591. https://doi.org/10.1007/ s13280-014-0501-3

The Strad. 2014. The Strad Directory 2014.

Trifkovic, S. 2016. Sustainable supply of wood for musical instruments. International Journal of Sustainable Future for Human Security 4(1):11-16. https://doi.org/10.24910/jsustain/4.1/1116 
United Nations Educational, Scientific and Cultural Organization (UNESCO). 1999. World Heritage Committee twenty-third session: report. Paris, France.

United Nations Educational, Scientific and Cultural Organization (UNESCO). 2001. World Heritage Committee twenty-fifth session: report. Paris, France.

United Nations Educational, Scientific and Cultural Organization (UNESCO). 2018. Basic texts of the 2003 Convention for the Safeguarding of the Intangible Cultural Heritage. Paris, France.

United Nations Educational, Scientific and Cultural Organization (UNESCO). 2019a. Decisions adopted during the 43rd session of the World Heritage Committee (Baku, 2019). Paris, France.

United Nations Educational, Scientific and Cultural Organization (UNESCO). 2019b. Operational guidelines for the implementation of the World Heritage Convention. Paris, France.

Varty, N. 1998. Caesalpinia echinata. IUCN Red List of Threatened Species. http://dx.doi.org/10.2305/IUCN.UK.1998. RLTS.T33974A9818224.en

Verburg, P. H., J. van de Steeg, A. Veldkamp, and L. Willemen. 2009. From land cover change to land function dynamics: a major challenge to improve land characterization. Journal of Environmental Management 90(3):1327-1335. https://doi. org/10.1016/j.jenvman.2008.08.005

Waleson, H. 2007. Imperiled pernambuco - an endangered tree casts a shadow over bow makers and musicians worldwide. Symphony (September-October):22-28.

Walker, B., and J. A. Meyers. 2004. Thresholds in ecological and social-ecological systems: a developing database. Ecology and Society 9(2):3. https://doi.org/10.5751/ES-00664-090203

Wilson, R., and J. Topham. 2004. Violins and climate. Theoretical and Applied Climatology 77(1-2):9-24. https://doi.org/10.1007/ s00704-003-0025-4

Winter, K., N. Lincoln, and F. Berkes. 2018. The social-ecological keystone concept: a quantifiable metaphor for understanding the structure, function, and resilience of a biocultural system. Sustainability 10(9):3294. https://doi.org/10.3390/su10093294

Zauer, M., and A. Pfriem. 2018. Tropical and traditional wood species in musical instruments and case studies of their substitution with modified wood. Pages 81-97 in M. A. Pérez, and E. Marconi, editors. Wooden musical instruments - different forms of knowledge. Book of end of WoodMusICK COST Action FP1302. Cit de la Musique; Prsence Graphique, Paris, France.

Zhang, H. Y. 2012. The study on application of artificial board materials in musical instrument-manufacturing engineering. Advanced Materials Research 583:255-258. https://doi. org/10.4028/www.scientific.net/AMR.583.255 
Appendix 1. Definitions of key terms and concepts

Table A1.1 Overview of definitions of key terms and concepts used in this study (alphabetical)

\begin{tabular}{ll}
\hline \hline Term & Definition \\
\hline Biocultural system & A linked biological and cultural system as found in indigenous \\
& contexts (Bond et al. 2019), whose focus lies on place-based cultural \\
perspectives that integrate values, needs, and knowledge and & recognizes feedback between ecological state and human well-being \\
& (Sterling et al. 2017). Underlying cultural processes are rooted in the \\
& biological necessities of the human life cycle and human biological \\
& processes are constrained, organized, and developed by culture \\
& (Carroll et al. 2017).
\end{tabular}

Culturalecological resilience

Culturalecological system

The capacity of a cultural-ecological system (CES) to absorb the effects of external drivers without losing the potential to provide ecosystem services (ES) (considering those species, resources, and functions relevant for cultural traditions) and for cultural traditions, to adapt to changes without losing essential (place-based and universal) traditional knowledge, experiences, and practices that have evolved and were passed on through generations. Similar to ecocultural resilience (Pretty 2011, Arora-Jonsson 2016), cultural-ecological resilience is a transdisciplinary understanding of a CES considering different scientific disciplines, cultures (including arts, craftsmanship, and music), paradigms, worldviews, languages, and institutional frameworks.

(CES)

Culturalecological tipping point

A social-ecological system (SES) that explicitly focuses on culture, the foundation of a society (Chun et al. 2006). CESs tackle the interlinkage of people and the environment including worldviews, cultural identities, values, cultural practices, and behaviors corresponding to a certain society, community, or group. CESs address ES delivered by intact ecosystems for the benefit of culture, thereby stressing cultural ES.

Level of one or several interlinked key ecological and/or cultural system variable(s) that, when crossed (similar to a tipping point defined by Chapin et al. 2009 and Folke et al. 2010) cause an abrupt change in the structure and function of a cultural-ecological system moving it to a new regime.

Cultural ecosystem Contributions of ecosystems to immaterial benefits for human wellservices being (Chan et al. 2012, Fish et al. 2016) depending on material (provisioning-cultural services, see definition below) and nonmaterial (cultural ecosystem services) nature's contributions to people (NCPs) (Díaz et al. 2018); their valuation is determined by people's values of nature (Kenter 2018) and by the perceived values of culture. 
Cultural heritage A subcategory of cultural ES (MEA 2005); humans created and shaped it in the past and presence in material (cultural goods) and immaterial (cultural practices and expressions) forms; it includes ideas and beliefs of societies and the resulting cultural objects represent material evidence of essential norms and values (Rusalić and Radojičić 2009).

Cultural keystone They deliver several material and non-material elements with crucial, species irreplaceable systemic functions and services for human well-being, hence they are essential in maintaining system integrity (Platten and Henfrey 2009) and depend on intact natural ecosystems.

Cross-scale interactions

Interactions within a hierarchically structured system spanning different scales (e.g. within the spatial, temporal, jurisdictional, institutional domain); they may change over time regarding their strength and direction; changes of interactions refer to dynamics of cross-scale linkages (Cash et al. 2006).

Dependence

It refers to well-being (physical, mental, social, and cultural) of key actors of the CES depending on a set of clearly defined ES (after Martín-López et al. 2019); in the case of pau-brasil: (a) direct and partial (economic) dependence on pau-brasil for livelihoods, (b) social, cultural, mental dependence on ES provided by pau-brasil beyond livelihoods, and (c) low dependence by actors potentially replaceable (e.g., scientists and environmental NGOs work for and with pau-brasil; policy makers are eager to approve protection laws for pau-brasil) (Fig. 6).

Driver External (exogenous) factors to a system that may cause changes in slow/controlling variables. They cannot be managed and are often related to specific events (of climate, markets, legislation, among others) and trigger local or cross-scale changes in the focal SES or CES (Walker et al. 2012).

Ecocultural system

"Complex dynamic systems of interactions between humans and the environment" (Rapport and Maffi 2010) that extend beyond social institutions and culturally diverse contexts of communities to include distinctive worldviews, values, diverse cultural practices, behaviors and identity (Pretty 2011). In contrast to CESs, ecocultural system thinking focuses mainly on local scales (Soini and Birkeland 2014).

Ecosystem services

Provision of goods and services by ecosystems of natural environments for human well-being (Costanza et al. 1997, Groot et al. 2002).

Feedback Result of an interaction between two or more system components that causes them to change, either in the same direction (amplifying feedback), ultimately destabilizing the system, or in the opposite direction (stabilizing feedback), thereby reducing fluctuations (Chapin et al. 2009). 
Heritage

Influence

Intangible cultural heritage

Metacoupled system

People's values of culture

People's values of nature

Regime
"A set of material or immaterial elements to which are attached specific values and rights that are linked to a social group and are inherited and transmitted from one generation to the next" (Michon et al. 2012); consequently the concept of heritage is a patrimonialization process of social, cultural, and political construction and as Olwig (2005) states, the role of nature or culture in shaping heritage identity depends on time and place. In contrast to ES, heritage has intergenerational relevance.

Influence of actors and actor groups (after Martín-López et al. 2019), where: (a) procedural equity or inequity refers to the direct control or decision-making power over management and policy decisions that affect ES. Procedural equity refers to the potential of different people/groups to influence decision making or having their perspectives incorporated or represented (Leach et al. 2018); and (b) distributional equity is the control over or power to influence management decisions that affect the access to ES. Distributional equity refers to how resources, benefits, and costs are distributed or shared among people and groups.

It encompasses the knowledge required and acquired for creating crafts (e.g., traditional bow making craftsmanship), languages, and traditions (Lowenthal 2005), which often includes tangible aspects (van Zanten 2004, Barthel-Bouchier 2016) such as musical instruments in music traditions and natural resources used in craftsmanship. Its focus is on traditional understandings and expressions, basically of "what people do and how they express themselves within their social context" (Dorfman 2011).

"A set of two or more coupled systems that interact internally as well as nearby and far away, facilitated by agents affected by various causes with various effects" (Liu 2017). A metacoupled system encompasses "human-nature interactions within a system (intracoupling) between adjacent systems (pericoupling) and between distant systems (telecoupling)" (Liu 2017).

Cultural values shared by a group/community or through legitimacy obtained by a socially accepted way of assigning value (e.g. disciplinary 'experts') attributed to be traditionally part of 'culture' (Stephenson 2008).

Societal importance/values assigned to nature shaping the perception of its ES/NCP (Kenter 2018), thus leading their decisions and behavior beyond a merely utilitarian perspective (Chan et al. 2016).

A desirable regime/stability domain of a SES or CES encompasses a set of alternative system states (Folke et al. 2010) each delivering a certain set of ES. 
Social-ecological A "system with interacting and interdependent physical, biological and system social components, emphasizing the 'humans-in-nature' perspective." (Chapin et al. 2009).

System variable A system is defined by its inherent system variables and the relationships among them (Walker et al. 2012); they encompass 'slow' and 'fast' variables that control the system resilience: 'slow' variables basically control ecological resilience, while either 'slow' or 'fast' variables control social (and cultural) resilience (Walker et al. 2012). For example, composition, musical instrument making, and societal structures are 'slow' variables, while crop cover controlled by 'slash and burn' and shifting agricultural practice is a 'fast' variable.

Tangible cultural It includes both moveable cultural objects and built monuments or heritage heritage sites. Tangible heritage emerges from intangible/immaterial knowledge, therefore "the immaterial heritage needs to be regarded as the larger framework within which material heritage takes on shape and significance" (Rusalić and Radojičić 2009).

Telecoupled CES Extending the definition of telecoupled SES by Liu et al. (2013), telecoupled CES consist of strong (socio-)cultural, socio-economic, and environmental interconnections and flows coupling cultural and natural subsystems to one integrated CES over large geographic distances.

Telecoupled SES Hierarchically structured SES characterized by strong socio-economic and ecological/environmental interactions and flows, thereby coupling human and natural systems over large distances (Liu et al. 2013).

Threshold/tipping Degree of one or several system variables (elements) that, when point crossed, cause an abrupt change in the structure and function of the SES/CES shifting the system to a new regime (Chapin et al. 2009, Folke et al. 2010).

Trigger event An internal or external punctual event, e.g., disturbance (storm, fire, etc.) or human activity (discovery, invention, decree, etc.) that triggers change in one or several system variables subsequently causing a change in system state or, when crossing a threshold or tipping point to a regime shift.

UNESCO cultural Refers to an outstanding universal value from the point of view of heritage history, arts/aesthetics, ethnology, anthropology and/or science (UNESCO 1972). It consists of tangible cultural heritage (monuments, groups of buildings, sites) (UNESCO 1972) and intangible cultural heritage (oral traditions and expressions, performing arts, social practices, rituals and festive events; knowledge and practices concerning nature and the universe and traditional craftsmanship) (UNESCO 2018). 
UNESCO natural Refers to an outstanding universal value as viewed by science, heritage conservation or due to the natural beauty/aesthetics for humanity (UNESCO 1972), it includes: (1) natural features (biotic and abiotic formations); (2) geologic or physiographic formations and precisely delineated areas, which constitute the habitat of threatened species, and (3) natural sites.

\section{Literature cited}

Allen, A. S. 2011. Prospects and Problems for Ecomusicology in Confronting a Crisis of Culture. Journal of the American Musicological Society 64(2):414-424.

Arora-Jonsson, S. 2016. Does resilience have a culture? Ecocultures and the politics of knowledge production. Ecological Economics 121:98-107.

Barthel-Bouchier, D. 2016. Cultural heritage: Tangible and intangible makers of collective memory. Pages 221-232 in A. L. Tota, and T. Hagen, editors. Routledge international handbook of memory studies. Routledge, London, New York.

Bond, M. O., B. J. Anderson, T. H. A. Henare, and P. M. Wehi. 2019. Effects of climatically shifting species distributions on biocultural relationships. People and Nature 1(1):87-102.

Brémaud, I., and N. Poidevin. 2013. Approches culturelles et mecaniques dans le choix des bois en facture: cas des archets anciens: Cultural and mechanical approaches in the choice of woods in instrument making the case of early bows. Pages 1-27 in M. Castellengo, and H. Genevois, editors. La musique et ses instruments. Editions Delatour France, Sampzon.

Brockhaus, editor. 1993. Der Brockhaus in fünf Bänden. 8. edition. F.A. Brockhaus GmbH, Mannheim.

Bueno, E. 2002. Pau-Brasil. Axis Mundi Ed, São Paulo.

Bunn, J., and L. R. Seiber. 1997. Music, makers and markets. The Strad.

Buono, A. J. 2012. Crafts of Color: Tupi Tapirage in Early Colonial Brazil in A. Feeser, M. D. Goggin, M. A. Feeser, and A. M. E. Yonan, editors. The Materiality of Color: The Production, Circulation, and Application of Dyes and Pigments, 1400-1800. Taylor and Francis, Florence.

Buono, A. J. 2016. Representing the Tupinambá and the Brazilwood Trade in Sixteenth-Century Rouen in R. R. Felix, and S. D. Juall, editors. Cultural Exchanges between Brazil and France. Purdue University Press, West Lafayette, Indiana.

Carroll, J., M. Clasen, E. Jonsson, A. R. Kratschmer, L. McKerracher, F. Riede, J.-C. Svenning, and P. C. Kjærgaard. 2017. Biocultural theory: The current state of knowledge. Evolutionary Behavioral Sciences 11(1):1-15.

Cash, D. W., W. N. Adger, F. Berkes, P. Garden, L. Lebel, P. Olsson, L. Pritchard, and O. Young. 2006. Scale and Cross-Scale Dynamics: Governance and Information in a Multilevel World. Ecology and Society 11(2).

Chan, K. M., T. Satterfield, and J. Goldstein. 2012. Rethinking ecosystem services to better address and navigate cultural values. Ecological Economics 74:8-18.

Chan, K. M. A., P. Balvanera, K. Benessaiah, M. Chapman, S. Díaz, E. Gómez-Baggethun, R. Gould, N. Hannahs, K. Jax, S. Klain, G. W. Luck, B. Martín-López, B. Muraca, B. Norton, K. Ott, U. Pascual, T. Satterfield, M. Tadaki, J. Taggart, and N. Turner. 2016. Opinion: Why protect nature? Rethinking values and the environment. Proceedings of the National Academy of Sciences of the United States of America 113(6):1462-1465.

Chapin, F. S., G. P. Kofinas, and C. Folke, editors. 2009. Principles of ecosystem stewardship: Resilience-based natural resource management in a changing world. Springer, New York, NY. 
Chun, C.-A., R. H. Moos, and R. C. Cronkite. 2006. Culture: A Fundamental Context for the Stress and Coping Paradigm. Pages 29-53 in P. T. P. Wong, L. C. J. Wong, and W. J. Lonner, editors. Handbook of multicultural perspectives on stress and coping. Springer, New York.

Costanza, R., R. d'Arge, R. de Groot, S. Farber, M. Grasso, B. Hannon, K. Limburg, S. Naeem, R. V. O'Neill, J. Paruelo, R. G. Raskin, P. Sutton, and M. van den Belt. 1997. The value of the world's ecosystem services and natural capital. Nature 387(6630):253-260.

da Silva Gomes, E. C. B., G. C. Jimenez, L. C. N. da Silva, F. B. de Sá, K. P. C. de Souza, G. S. Paiva, and I. A. de Souza. 2014. Evaluation of antioxidant and antiangiogenic properties of caesalpinia echinata extracts. Journal of Cancer 5(2):143-150.

Dapson, R., and C. Bain. 2015. Brazilwood, sappanwood, brazilin and the red dye brazilein: from textile dyeing and folk medicine to biological staining and musical instruments. Biotechnic \& Histochemistry 90(6):401-423.

Dean, W. 1996. A ferro e fogo: A história e a devastação da mata atlântica brasileira. 6. edition. Companhia das letras, São Paulo.

Díaz, S., U. Pascual, M. Stenseke, B. Martín-López, R. T. Watson, Z. Molnár, R. Hill, K. M. A. Chan, I. A. Baste, K. A. Brauman, S. Polasky, A. Church, M. Lonsdale, A. Larigauderie, P. W. Leadley, A. P. E. van Oudenhoven, F. van der Plaat, M. Schröter, S. Lavorel, Y. Aumeeruddy-Thomas, E. Bukvareva, K. Davies, S. Demissew, G. Erpul, P. Failler, C. A. Guerra, C. L. Hewitt, H. Keune, S. Lindley, and Y. Shirayama. 2018. Assessing nature's contributions to people. Science (New York, N.Y.) 359(6373):270-272.

Dickason, O. P. 1984. The Brazilian connection. A look at the origin of French techniques for trading with Amerindians. Revue française d'histoire d'outre-mer 71(264):129-146.

Dorfman, E. 2011. Intangible Natural Heritage: An introduction. Pages 1-15 in E. Dorfman, editor. Intangible natural heritage: New perspectives on natural objects. Routledge, London.

Femke, C. 2014. A Challenge to tradition. Accessories October:4-7.

Fish, R., A. Church, and M. Winter. 2016. Conceptualising cultural ecosystem services: A novel framework for research and critical engagement. Ecosystem Services 21:208-217.

Folke, C., S. R. Carpenter, B. Walker, M. Scheffer, T. Chapin, and J. Rockström. 2010. Resilience thinking: Integrating resilience, adaptability and transformability. Ecology and Society 15(4):20. [online] URL: http://www.ecologyandsociety.org/vol15/iss4/art20/.

Fraga Campos, F., P. A. Sales Junior, A. J. Romanha, M. S. S. Araújo, E. P. Siqueira, J. M. Resende, T. M. A. Alves, O. A. Martins-Filho, V. L. dos Santos, C. A. Rosa, C. L. Zani, and B. B. Cota. 2015. Bioactive endophytic fungi isolated from Caesalpinia echinata Lam. (Brazilwood) and identification of beauvericin as a trypanocidal metabolite from Fusarium sp. Memorias do Instituto Oswaldo Cruz 110(1):65-74.

Gerbeth, T. M. 2002. Pernambuco Sonderausgabe, Wien.

Grangeiro, A. R. S. 2009. Avaliação do potencial toxicológico e farmacológico de Caesalpinia echinata Lam.

Groot, R. S. D., M. a. Wilson, and R. M. Boumans. 2002. A typology for the classification, description and valuation of ecosystem functions, goods and services. Ecological Economics 41(3):393-408.

Halbscheffel, B. 2010. Lexikon Musikinstrumente Instrumente, Spielweisen, Begriffe. Halbscheffel Verlag, Leipzig.

Hume, D. 2008. Quality and Quantity. The Strad October:38-42.

Kenter, J. O. 2018. IPBES: Don't throw out the baby whilst keeping the bathwater; Put people's values central, not nature's contributions. Ecosystem Services 33:40-43.

Komission für Musikforschung. 2013. Österreichisches Musiklexikon. Verlag der Österreichischen Akademie der Wissenschaften, Wien. 
Leach, M., B. Reyers, X. Bai, E. S. Brondizio, C. Cook, S. Díaz, G. Espindola, M. Scobie, M. Stafford-Smith, and S. M. Subramanian. 2018. Equity and sustainability in the Anthropocene: a social-ecological systems perspective on their intertwined futures. Global Sustainability 1.

Liu, J. 2017. Integration across a metacoupled world. Ecology and Society 22(4).

Liu, J., V. Hull, M. Batistella, R. DeFries, T. Dietz, F. Fu, T. W. Hertel, R. C. Izaurralde, E. F. Lambin, S. Li, L. A. Martinelli, W. J. McConnell, E. F. Moran, R. Naylor, Z. Ouyang, K. R. Polenske, A. Reenberg, G. de Miranda Rocha, C. S. Simmons, P. H. Verburg, P. M. Vitousek, F. Zhang, and C. Zhu. 2013. Framing Sustainability in a Telecoupled World. Ecology and Society 18(2). [online] URL: http://dx.doi.org/10.5751/ES-05873-180226.

Lockett, M., and C. R. Littler. 1983. Trends in Chinese enterprise management, 1978-1982. World Development 11(8):683-704.

Lowenthal, D. 2005. Natural and cultural heritage. International Journal of Heritage Studies Vol. 11(No. 1):81-92.

Macedo, T. M. 2015. Variação intraespecífica do lenho e dendrocronologia de Caesalpinia echinata Lam na Floresta Atlântica. Universidade Federal do Rio de Janeiro (UFRJ).

Macedo, T. M., C. G. Costa, H. C. d. Lima, and C. F. Barros. 2020. Wood anatomy of historic French violin bows made of Pernambuco wood. International Association of Wood Anatomists (IAWA Journal):1-13.

Martín-López, B., M. R. Felipe-Lucia, E. M. Bennett, A. Norström, G. Peterson, T. Plieninger, C. C. Hicks, F. Turkelboom, M. García-Llorente, S. Jacobs, S. Lavorel, and B. Locatelli. 2019. A novel telecoupling framework to assess social relations across spatial scales for ecosystem services research. Journal of environmental management 241:251-263.

MEA. 2005. Ecosystems and human well-being: Synthesis. Island Press, Washington, DC.

Michon, G., B. Romagny, L. Auclair, and M. Deconchat. 2012. Forests as Patrimonies? From Theory to Tangible Processes at Various Scales. Ecology and Society 17(3):7. [online] URL: http://dx.doi.org/10.5751/ES-04896-170307.

Mnatzaganain, S. 2002. Objects of desire. The Strad 8:816-820.

Moore, J. W. 2002. The Crisis of Feudalism. Organization \& Environment 15(3):301-322.

Nehren, U. 2011. Historische Landschaftsdegradation und aktuelle Nutzungsproblematik in der Serra dos Órgãos Rio de Janeiro. Pages 11-25 in Neuburger, Martin Coy \& Martina, editor. Global Change: Herausforderungen für Lateinamerika. Bd. 38. Innsbrucker Geographische Studien.

Olwig, K. R. 2005. Introduction: the nature of cultural heritage, and the culture of natural heritagenorthern perspectives on a contested patrimony. International Journal of Heritage Studies 11(1):3-7.

Peterson, G. 2000. Political ecology and ecological resilience: An integration of human and ecological dynamics. Ecological Economics 35:323-336. [online] URL:

http://www.sciencedirect.com/science/article/pii/S0921800900002172.

Pfeifer, E. 2002. Violin Bows Go High Tech. The Wall Street Journal.

Pinheiro, A. 1991. Tradução científica, tradução cultural, tradução poética. Revista USP.

Platten, S., and T. Henfrey. 2009. The Cultural Keystone Concept: Insights from Ecological Anthropology. Human Ecology 37(4):491-500.

Pretty, J. 2011. Interdisciplinary progress in approaches to address social-ecological and ecocultural systems. Environmental Conservation 38(02):127-139.

Rapport, D., and L. Maffi. 2010. The dual erosion of biological and cultural diversity: implications for the health of ecocultural systems. Pages 103-122 in S. Pilgrim, and J. N. Pretty, editors. Nature and culture: Rebuilding lost connections. Earthscan, London, Washington D.C.

Retford, W. C. 1964. Bows and Bow makers. 1. edition. Strad, London. 
Rocha, Y. T. 2004. Ibirapitanga: história, distribuição geográfica e conservação do pau-brasil (Caesalpinia echinata Lam., Leguminosae) do descobrimento à atualidade. Universidade de São Paulo, São Paulo.

Rocha, Y. T., A. Presotto, and F. Cavalheiro. 2007. The representation of Caesalpinia echinata (Brazilwood) in Sixteenth-and-Seventeenth-Century Maps. Anais da Academia Brasileira de Ciências 79(4):751-765.

Rusalić, D., and D. Radojičić. 2009. Making the intangible tangible: The new interface of cultural heritage. Institute of Etnography SASA, Beograd.

Rymer, R. 2004. Saving the music tree: Artists and instrument makers have banded together to rescue Brazil's imperiled pernambuco, the source of bows for violins, violas and cellos. Smithsonian Magazine April.

Rymer, R. 2007. A fight for survival. The Strad June:28-32.

Sadler, N. 2007. Endangered species: Naomi Sadler reports on a recent conference to decide whether to restrict the trade in pernambuco wood, and looks at what is being done to save Brazil's imperilled national tree. Double Bassist(43):29-32.

Silva, A. J. d. R., and L. d. H. C. Andrade. 2006. Cultural Significance of Plants in Communities Located in the Coastal Forest Zone of the State of Pernambuco, Brazil. Human Ecology 34(3):447-465.

Siqueira, E. P., C. L. Zani, T. Maria, A. Alves, M. Patrícia, O. A. M. Filho, M. S. S. Araújo, E. M. Teixeira, M. Melo, R. Serákides, and B. B. Cota. 2014. Evaluation of the In vitro leishmanicidal and In vivo acute oral toxicity of the Caesalpinia echinata L extracts as source of natural products against leishmaniasis. Journal of Natural Product and Plant Resource 4(3):30-38.

Skeaping, K. 1955. Some Speculations on a Crisis in the History of the Violin. The Galpin Society Journal Vol. 8:3-12. [online] URL: http://www.jstor.org/stable/842152.

Soini, K., and I. Birkeland. 2014. Exploring the scientific discourse on cultural sustainability. Geoforum 51:213-223.

Stephenson, J. 2008. The Cultural Values Model: An integrated approach to values in landscapes. Landscape and Urban Planning 84(2):127-139.

Sterling, E. J., C. Filardi, A. Toomey, A. Sigouin, E. Betley, N. Gazit, J. Newell, S. Albert, D. Alvira, N. Bergamini, M. Blair, D. Boseto, K. Burrows, N. Bynum, S. Caillon, J. E. Caselle, J. Claudet, G. Cullman, R. Dacks, P. B. Eyzaguirre, S. Gray, J. Herrera, P. Kenilorea, K. Kinney, N. Kurashima, S. Macey, C. Malone, S. Mauli, J. McCarter, H. McMillen, P. Pascua, P. Pikacha, A. L. Porzecanski, P. de Robert, M. Salpeteur, M. Sirikolo, M. H. Stege, K. Stege, T. Ticktin, R. Vave, A. Wali, P. West, K. B. Winter, and S. D. Jupiter. 2017. Biocultural approaches to well-being and sustainability indicators across scales. Nature ecology \& evolution 1(12):1798-1806.

UNESCO. 1972. Convention concerning the Protection of the World Cultural and Natural Heritage.

UNESCO. 2012. Intergovernmental Commitee for the Safeguarding of the Intangible Cultural Heritage: Decisions. Convention for the Safeguarding of the Intangible Cultural Heritage.

UNESCO. 2018. Basic Texts of the 2003 Convention for the Safeguarding of the Intangible Cultural Heritage. Living Heritage.

van Zanten, W. 2004. Constructing New Terminology for Intangible Cultural Heritage. Museum International 56(1-2):36-44.

Varty, N. 1998. Caesalpinia echinata. The IUCN Red List of Threatened Species:1-10. [online] URL: http://dx.doi.org/10.2305/IUCN.UK.1998.RLTS.T33974A9818224.en.

Walker, B. H., S. R. Carpenter, J. Rockstrom, A. S. Crépin, and G. D. Peterson. 2012. Drivers, "Slow" Variables, "Fast" Variables, Shocks, and Resilience. Ecology and Society 17(3):30. [online] URL: http://dx.doi.org/10.5751/ES-05063-170330.

Zanin, J. L. B., B. a. de Carvalho, P. S. Martineli, M. H. dos Santos, J. H. G. Lago, P. Sartorelli, C. Viegas, and M. G. Soares. 2012. The genus Caesalpinia L. (Caesalpiniaceae): phytochemical and 
pharmacological characteristics. Molecules (Basel, Switzerland) 17(7):7887-7902. [online] URL: http://www.ncbi.nlm.nih.gov/pubmed/22751225. 
Appendix 2. Potentials and application of the telecoupled cultural-ecological system's approach

Table A2.1 Examples of potential future applications of the telecoupled cultural-ecological system's approach

\begin{tabular}{|c|c|c|c|c|c|}
\hline No & CES-A / CES-B & $\begin{array}{l}\text { Key cultural } \\
\text { element(s) }\end{array}$ & $\begin{array}{l}\text { Key ecological } \\
\text { element(s) }\end{array}$ & $\begin{array}{l}\text { Flows of } \\
\text { material NCPs }\end{array}$ & $\begin{array}{l}\text { Flows of non- } \\
\text { material NCPs }\end{array}$ \\
\hline \multirow[t]{2}{*}{1} & $\begin{array}{l}\text { CES-A: Coastal } \\
\text { area of Kenya, } \\
\text { Tanzania, } \\
\text { Mozambique }\end{array}$ & $\begin{array}{l}\text { CES-A: } \\
\text { Woodcarving } \\
\text { tradition }\end{array}$ & $\begin{array}{l}\text { CES-A: African } \\
\text { blackwood tree } \\
\text { (Dalbergia } \\
\text { melanoxylon) }\end{array}$ & $\begin{array}{l}\text { CES-A to } \\
\text { CES-B: } \\
\text { Blackwood } \\
\text { (provisioning- } \\
\text { cultural } \\
\text { service) }\end{array}$ & $\begin{array}{l}\text { CES-A: African } \\
\text { blackwood giving } \\
\text { identity (national } \\
\text { tree) }\end{array}$ \\
\hline & CES-B: Europe & $\begin{array}{l}\text { CES-B: } \\
\text { Crafting } \\
\text { oboes, } \\
\text { clarinets, and } \\
\text { bagpipes }\end{array}$ & $\begin{array}{l}\text { CES-B: Cork oak } \\
\text { tree (Quercus } \\
\text { suber) }\end{array}$ & & \\
\hline \multirow[t]{2}{*}{2} & $\begin{array}{l}\text { CES-A: Latin } \\
\text { America, } \\
\text { especially } \\
\text { Mexico }\end{array}$ & $\begin{array}{l}\text { CES-A: } \\
\text { Indigenous } \\
\text { traditional } \\
\text { dyeing } \\
\text { technique, } \\
\text { handmade } \\
\text { textiles }\end{array}$ & $\begin{array}{l}\text { CES-A: } \\
\text { Cochineal } \\
\text { (Dactylopius } \\
\text { coccus) }\end{array}$ & $\begin{array}{l}\text { CES-A to } \\
\text { CES-B: } \\
\text { Cochineal } \\
\text { (provisioning- } \\
\text { cultural } \\
\text { service) }\end{array}$ & $\begin{array}{l}\text { CES-A: possible } \\
\text { non-material } \\
\text { NCP/ES for } \\
\text { indigenous } \\
\text { people (further } \\
\text { research is } \\
\text { needed) }\end{array}$ \\
\hline & CES-B: Europe & $\begin{array}{l}\text { CES-B: } \\
\text { painting, } \\
\text { handicrafts, } \\
\text { tapestries, } \\
\text { varnish } \\
\text { ingredients }\end{array}$ & $\begin{array}{l}\text { CES-B: other } \\
\text { colorants for } \\
\text { painting, } \\
\text { handicrafts and } \\
\text { as varnish } \\
\text { ingredients (e.g., } \\
\text { turpentine, } \\
\text { shellac) }\end{array}$ & & $\begin{array}{l}\text { CES-A/CES-B } \\
\text { cultural exchange } \\
\text { on applications of } \\
\text { cochineal as dye }\end{array}$ \\
\hline \multirow[t]{2}{*}{3} & $\begin{array}{l}\text { CES-A: South } \\
\text { and Southeast } \\
\text { Asia (especially } \\
\text { India and } \\
\text { Thailand) }\end{array}$ & $\begin{array}{l}\text { CES-A: } \\
\text { traditional dye } \\
\text { for silk cloth } \\
\text { in Thailand }\end{array}$ & $\begin{array}{l}\text { CES-A: Shellac } \\
\text { (Kerria lacca) }\end{array}$ & $\begin{array}{l}\text { CES-A to } \\
\text { CES-B: } \\
\text { shellac } \\
\text { (provisioning- } \\
\text { cultural } \\
\text { service) }\end{array}$ & $\begin{array}{l}\text { CES-A to CES- } \\
\text { B: Cultural } \\
\text { exchange of uses } \\
\text { of shellac }\end{array}$ \\
\hline & CES-B: Europe & $\begin{array}{l}\text { CES-B: } \\
\text { traditional use } \\
\text { of varnishes of } \\
\text { musical } \\
\text { instruments }\end{array}$ & $\begin{array}{l}\text { CES-B: other } \\
\text { varnish } \\
\text { ingredients (e.g., } \\
\text { natural colorants, } \\
\text { copal) }\end{array}$ & & \\
\hline
\end{tabular}




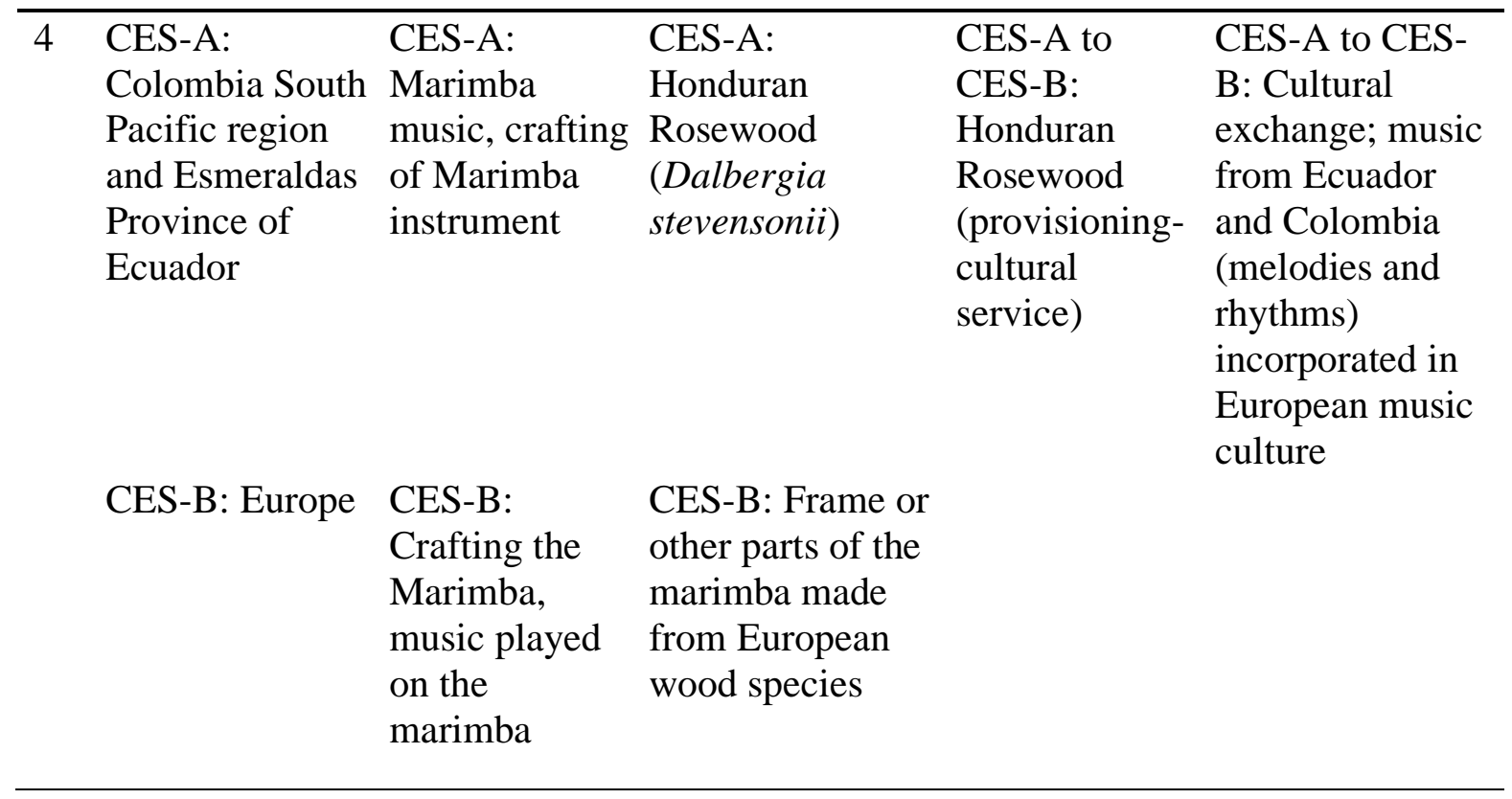


Appendix 3. Literature review

Literature review relevant for the analysis of the historical trajectory of the PB-CES

Table A3.1 Literature review regarding historical interconnections and relations within and between our thematic dimensions of (1) classical music, (2) violin and bow making, (3) the natural environment, and (4) socio-political and economic contexts considering the scale of the Mata Atlântica biome, Europe and globally

\begin{tabular}{ll}
\hline \hline Type of literature & Description \\
\hline Musicological & $\begin{array}{l}\text { Developments in composition (e.g., complexity } \\
\text { and virtuosity); ensemble types and sizes; } \\
\text { instruments used; type, size, and location of } \\
\text { concerts; spreading of performances and new } \\
\text { compositions of classical music in and outside } \\
\text { of Europe between } 1500 \text { and present day. }\end{array}$ \\
& $\begin{array}{l}\text { Temporal developments in professions of } \\
\text { musical instrument manufacturing (e.g., bow } \\
\text { Violin and bow } \\
\text { making specialist } \\
\text { literature }\end{array}$ \\
$\begin{array}{l}\text { choice of musical instruments; changes in } \\
\text { financial value and appreciation of musical } \\
\text { instrument bows; standardization of } \\
\text { construction methods; change of size of musical } \\
\text { instruments, and corresponding changes in the } \\
\text { development of classical music. }\end{array}$
\end{tabular}

Archived historical Accounts of historic bow making manufactories records in Markneukirchen, Mittenwald, Mirecourt, and Paris representing the main historical string instrument crafting centers; reports of German craft guilds regarding trade data of raw material and finished instruments with material specification.

Key words

Violin bow, baroque bow, musical instruments

Raw materials, specification on material choice, changes baroque instruments to modern musical instruments

Lists of ordered materials, list of constructed bows per material and origin of materials

Bow and violin

Representation of the reactions of violin and Journals: The making journals bow makers on the threat of pau-brasil and its listing in the CITES Appendix II.

Strad, Double

Bassist, Das

Orchester

Wood anatomy, dendrochronology, Alternative materials for pau-brasil, criteria for material science material choices for making bows of string instruments, comparison of wood quality from wild populations and plantations of pau-brasil.

Alternative wood species, acoustical characteristics of pau-brasil, wood from plantations

Natural sciences Mata Atlântica biome: changes in forest Natural (forestry, biology, distribution and loss in relation to economic and distribution of 


\begin{tabular}{lll}
\hline \hline $\begin{array}{l}\text { agriculture, } \\
\text { environmental } \\
\text { sciences) }\end{array}$ & $\begin{array}{l}\text { political changes, current distribution of pau- } \\
\text { brasil, state-of-the art of native tree species and } \\
\text { pau-brasil plantations within the Mata Atlântica } \\
\text { and on the natural distribution of pau-brasil. }\end{array}$ & $\begin{array}{l}\text { pau-brasil, range } \\
\text { map of }\end{array}$ \\
$\begin{array}{l}\text { Paubrasilia } \\
\text { echinata, pau- } \\
\text { brasil plantations, } \\
\text { pau-brasil } \\
\text { population trend }\end{array}$ \\
$\begin{array}{l}\text { Literature historical } \\
\text { sciences }\end{array}$ & $\begin{array}{l}\text { Political power structures over time (e.g., } \\
\text { conquest and colonialization, Brazilian } \\
\text { independence, Portuguese monopoly on pau- } \\
\text { brasil), economic aspects of pau-brasil (trade } \\
\text { routes, pau-brasil trade, economic relevance, } \\
\text { and changes of use from dye to bows). }\end{array}$ & $\begin{array}{l}\text { Pau-brasil trade, } \\
\text { Monopoly on } \\
\text { pau-brasil, pau- } \\
\text { brasil economic } \\
\text { value }\end{array}$ \\
\hline CITES trade data & $\begin{array}{l}\text { Worldwide registered legal trade data of pau- } \\
\text { brasil (2007-2020). }\end{array}$ & $\begin{array}{l}\text { Paubrasilia } \\
\text { echinata }\end{array}$ \\
\hline
\end{tabular}

Literature review relevant for the social and power relations analysis

Table A3.2 Literature review regarding the Nature's Contribution to People (NCPs)/Ecosystem Services (ESs) of pau-brasil (see details Appendix 6, Table A6.1) and indicating sources for social interconnections and influences of social actors on policy decisions and the management of NCP/ES of pau-brasil in the Mata Atlântica region, Europe and globally.

\begin{tabular}{lll}
\hline Type of literature & Description & Key words \\
\hline $\begin{array}{l}\text { Pharmacy } \\
\text { literature }\end{array}$ & $\begin{array}{l}\text { Search for pharmaceutical use of } \\
\text { pau-brasil, healing effects or } \\
\text { compounds that are of medicinal } \\
\text { interest. }\end{array}$ & $\begin{array}{l}\text { Pau-brasil / Paubrasilia echinata } \\
\text { and pharmaceutical use, } \\
\text { medicinal effects of pau-brasil / } \\
\text { Paubrasilia echinata }\end{array}$ \\
$\begin{array}{l}\text { Taxonomy and } \\
\text { ecology literature }\end{array}$ & $\begin{array}{l}\text { Search regarding the effects of pau- } \\
\text { brasil on soil, its habitat, and/or } \\
\text { other organisms. }\end{array}$ & $\begin{array}{l}\text { Nitrogen fixation Paubrasilia } \\
\text { echinata, Paubrasilia echinata } \\
\text { and soil }\end{array}$ \\
$\begin{array}{l}\text { Anthropology } \\
\text { literature and } \\
\text { literature on } \\
\text { cultural heritage }\end{array}$ & $\begin{array}{l}\text { Search for non-material NCPs } \\
\text { described in the literature. }\end{array}$ & $\begin{array}{l}\text { Pau-brasil and identity, pau- } \\
\text { brasil and inspiration, pau-brasil } \\
\text { and sense of place }\end{array}$ \\
$\begin{array}{l}\text { Scientific } \\
\text { literature in } \\
\text { general }\end{array}$ & $\begin{array}{l}\text { General relevance of research on } \\
\text { pau-brasil and of pau-brasil for } \\
\text { educational reasons. }\end{array}$ & $\begin{array}{l}\text { Publications found with Scopus } \\
\text { with the search string: }\end{array}$ \\
& & "Caesalpinia echinata" OR \\
& & $\begin{array}{l}\text { "brazilwood" OR "pau-brasil" } \\
\text { OR "pernambuco wood" OR }\end{array}$ \\
& & "Paubrasilia echinata": 205 \\
& &
\end{tabular}


CITES meeting List of participants and their reports contributions as an indicator for

social interconnections and influence on policy decisions
Participants, violin maker, bow maker, environmental NGO, environmental agencies 
Appendix 4. Semi-structured interviews

Conducted interviews and their main contents relevant to the respective research questions

Table A4.1 List of interviews with actors of the main actor groups including representatives of institutions, initiatives, and associations (EUR= Europe, BRA=Brazil, MA= Mata Atlântica)

\begin{tabular}{|c|c|c|c|}
\hline Affiliated actor group & Considered institutions / initiatives / associations & $\mathrm{N}$ & Scale \\
\hline \multirow[t]{3}{*}{ Bow maker } & $\begin{array}{l}\text { International Pernambuco Conservation Initiative } \\
\text { (IPCI) }\end{array}$ & 1 & EUR \\
\hline & Individual bow maker & 1 & BRA \\
\hline & Individual bow makers & 4 & MA \\
\hline Environmental agency & $\begin{array}{l}\text { Instituto Brasileiro do Meio Ambiente e dos } \\
\text { Recursos Naturais Renováveis (IBAMA), Instituto } \\
\text { Chico Mendes de Conservação da Biodiversidade, } \\
\text { (ICM-Bio) }\end{array}$ & 4 & MA \\
\hline Environmental NGO & $\begin{array}{l}\text { Associação Plantas do Nordeste (APNE), Floresta } \\
\text { Viva, Fundação Nacional do Pau Brasil, SOS Mata } \\
\text { Atlântica, }\end{array}$ & 4 & MA \\
\hline Scientists & $\begin{array}{l}\text { Instituto Florestal São Paulo, Universidade de São } \\
\text { Paulo, Universidade Federal do Espírito Santo, } \\
\text { Jardim Botânico de Rio de Janeiro (JBRJ) }\end{array}$ & 8 & BRA \\
\hline Violin maker & Individual violin makers & 3 & $\begin{array}{l}\text { EUR, } \\
\text { INT }\end{array}$ \\
\hline Farmers/Forest ranger & $\begin{array}{l}\text { Comissão Executiva do Plano da Lavoura } \\
\text { Cacaueira (CEPLAC) }\end{array}$ & 9 & MA \\
\hline
\end{tabular}


Historical trajectory analysis

Table A4.2 Main aspects of the semi-structured interviews for the historical trajectory analysis

\begin{tabular}{|c|c|}
\hline Affiliated actor group & Description of main aspects \\
\hline Environmental NGOs & $\begin{array}{l}\text { Experiences in reforestation and tree nurseries in the Mata } \\
\text { Atlântica, pau-brasil plantations in agroforestry systems (with } \\
\text { small-scale farmers), pau-brasil plantations in the northeast in } \\
\text { monocultures and agroforestry systems. History of first pau- } \\
\text { brasil plantations to protect and conserve the species, period of } \\
\text { existing pau-brasil planting projects, type of funding, } \\
\text { difficulties/challenges in reforestation projects, type of planting } \\
\text { projects/plantations (forest enrichment, monoculture, } \\
\text { agroforestry system, mixed plantation, plans for future } \\
\text { commercial use); involved actors (small-holder farmers, big- } \\
\text { scale farmers, bow makers with their own territories), number } \\
\text { and type of plantations that fulfill all criteria for future } \\
\text { commercial use. }\end{array}$ \\
\hline $\begin{array}{l}\text { Farmers, plantation } \\
\text { owners, rangers }\end{array}$ & $\begin{array}{l}\text { Interest of integrating pau-brasil in cocoa plantations } \\
\text { (agroforestry systems), potential of pau-brasil within native } \\
\text { mixed tree plantations and future legal use (obstacles), ecological } \\
\text { and protection situation, potentials for planting pau-brasil in } \\
\text { areas of small-scale farmers. }\end{array}$ \\
\hline $\begin{array}{l}\text { Bow (incl. subgroup: } \\
\text { bow manufactories) and } \\
\text { violin makers }\end{array}$ & $\begin{array}{l}\text { Current situation of bow making in Europe, traditional } \\
\text { knowledge on wood properties and choice, construction of high- } \\
\text { quality bows, bow making in Brazil, situation within the bow } \\
\text { making manufactories in Brazil, situation of private pau-brasil } \\
\text { plantations of owners of the bow making manufactories, trade of } \\
\text { legal pau-brasil, awareness of violin makers about the situation } \\
\text { of pau-brasil. }\end{array}$ \\
\hline $\begin{array}{l}\text { Scientists (experts), } \\
\text { research on pau-brasil }\end{array}$ & $\begin{array}{l}\text { Overall situation of pau-brasil, actual distribution, wood anatomy } \\
\text { of pau-brasil, alternative wood species for making bows for } \\
\text { string instruments, information on morphotypes, genetic } \\
\text { variations, dendrochronology, and its cultural value for } \\
\text { Brazilians. }\end{array}$ \\
\hline
\end{tabular}


Social actor and power relations analysis

Table A4.3 Main aspects of the semi-structured interviews for the social actor and power relations analysis

\begin{tabular}{|c|c|}
\hline $\begin{array}{l}\text { Affiliated actor } \\
\text { group }\end{array}$ & Description of main aspects \\
\hline $\begin{array}{l}\text { All interview } \\
\text { respondents }\end{array}$ & $\begin{array}{l}\text { Origin, age, gender; recommendation on which other key actors should be } \\
\text { approached (snowball sample), profession, representative position. }\end{array}$ \\
\hline $\begin{array}{l}\text { Environmental } \\
\text { NGOs }\end{array}$ & $\begin{array}{l}\text { Scale of action, level of concern regarding pau-brasil and its ES, existence } \\
\text { of interconnections to other NGOs or actor groups, level of influence on } \\
\text { policy decisions, e.g., consultation as experts of decision-making } \\
\text { processes regarding native species and pau-brasil and at what scales. }\end{array}$ \\
\hline $\begin{array}{l}\text { Bow makers/ } \\
\text { violin makers }\end{array}$ & $\begin{array}{l}\text { Existence of associations (Brazil, Europe, International), role of pau-brasil } \\
\text { in livelihoods, existence of connections among bow makers across scales, } \\
\text { level of influence in decision making processes and policy decisions. }\end{array}$ \\
\hline $\begin{array}{l}\text { Farmers/ } \\
\text { plantation or } \\
\text { forest owners }\end{array}$ & $\begin{array}{l}\text { Role of pau-brasil and its ES for livelihoods, concern over pau-brasil, } \\
\text { cultural importance, existence of farmer associations (formal } \\
\text { institutionalization), interconnections with other actor groups at different } \\
\text { scales, possibilities for participation and influence in decision-making } \\
\text { processes. }\end{array}$ \\
\hline Scientists & $\begin{array}{l}\text { Concerns about pau-brasil from the scientific community at all scales, } \\
\text { level of influence on decision-making processes or policy decisions, e.g., } \\
\text { consultation as experts to assess the threats to pau-brasil. }\end{array}$ \\
\hline
\end{tabular}




\section{Interview scripts}

\section{Bow makers/violin makers}

1. When was your company/workshop founded?

2. Are you a bow maker/violin maker personally?

3. Was there a history of bow making within your family?

4. Was there a specific moment when the situation in respect of pau-brasil worsened?

5. How many bows per year do you produce/sell in your workshop? Are these bows all made from Pernambuco wood?

6. For how long do you consider having enough Pernambuco wood in your stock? (only bow makers)

7. Under the consideration of the market of string instrument bows, there are bows on the market under the trade name 'Brasilholz'/'brazilwood'; what tree species is meant with that trade name for violin and bow makers?

8. Do you think it will also be possible in future to build string instrument bows made from pernambuco wood/pau-brasil?

9. In how far is the Chinese Market affecting the situation of your company/workshop, of the Mata Atlântica and of Brazil?

10. To your opinion are there any other wood species that could replace pernambuco wood?

11. To your experience do you think musicians would buy bows made from other wood species?

12. How much influence has the Chinese bow production on the Brazilian/European market?

13. What were generally the most important changes in the bow making tradition?

14. Which key characteristics does pernambuco wood fulfill for making string instrument bows?

15. In how far does storing time of wood influence the wood quality?

16. In the literature one can read that one bow needs on average $1 \mathrm{~kg}$ of raw material, can you confirm that? Or what are your experiences?

17. Talking about the NGO IPCI, how many German members does the NGO have? (only for IPCI)

18. What do you think is the biggest threat for bow making?

19. Considering the situation of the pernambuco tree, to what extent can its use in bow making be linked to the threat of the tree species?

20. Which are the difficulties using alternative wood species?

21. Do you think certification of pernambuco wood could be a solution for the problem?

22. When did you buy the last time pernambuco wood?

23. Did you notice increasing prices? And if so, how much did prices increase?

24. Based on your experience did the supply of pernambuco string instrument bows increase or decrease?

25. Where do you need to register your pernambuco stock in Germany/Brazil?

\section{Environmental agencies}

1. Which are the relevant laws at the federal level for the conservation of endemic native tree species in danger of extinction?

2. Is there any specific law for the protection or conservation of pau-brasil?

3. Which are the relevant laws on the federal level for plantations of endangered native tree species with the goal of a future commercial use?

4. Is there any specific law for pau-brasil plantations related to future commercial use? 
5. Are there any specific laws on the state level for the regulation of plantations of endangered native species or especially for pau-brasil with the goal of a future commercial use?

6. Are there any specific laws on the state level for the conservation of native species or especially for pau-brasil?

7. Based on the legislative regulations is it theoretically possible to have mixed silviculture plantations only with native tree species of the Mata Atlântica?

8. Are there any limitations for a future commercial use of planted native tree species and especially of pau-brasil trees?

9. How is the process of the registration of an area for cultivating native tree species?

10. Is there a national register about confiscated wood/illegal trade of native and/or protected species? Specifically, also for pau-brasil?

11. When was the last case when pau-brasil got confiscated?

12. Do you know if there exists a central federal or state register of the registered legal stocks of pau-brasil?

13. From which date onwards was it necessary to register pau-brasil stocks in Brazil?

14. Is there any data available on legal trade of pau-brasil in the past or nowadays?

15. What do you consider the biggest problem in the protection and conservation of paubrasil?

\section{Environmental NGOs/ Farmers association (CEPLAC)}

1. What is the focus of your NGO?

2. Which are the most valued species of the Mata Atlântica?

3. Since how long have you been working with pau-brasil within the work of your NGO?

4. Which are the aspects of pau-brasil you are working with?

5. In which regions are you working with pau-brasil?

6. Since how long are you working together with IPCI?

7. Do you think that a sustainable use of pau-brasil is possible?

8. Do you think it is possible to include small-scale farmers in a sustainable use of paubrasil?

9. Would you consider a commercial monoculture with pau-brasil as a possibility for sustainable cultivation?

10. There are many other existential problems for farmers in your region. Nevertheless, do you think that there are possibilities for sustainable pau-brasil plantation activities in your region?

11. How does climate change manifest in this region here?

12. Do you think climate change will potentially affect the growth and success of pau-brasil plantations?

13. Are there any findings on how drought affects the growth of pau-brasil?

14. What are the main potentials and obstacles that you would name talking about pau-brasil protection and its future commercial use?

15. Do you consider it a realistic option to establish mixed pau-brasil plantations with cocoa and other agricultural plants?

16. What is your opinion about nature-oriented silviculture for a future commercial use of pau-brasil?

17. Do you also work with other endemic tree species of the Mata Atlântica besides paubrasil? 


\section{Farmers}

1. What do you plant on your farm?

2. What is your motivation to plant pau-brasil?

3. Does pau-brasil have a specific importance for you?

4. How did you get the idea to plant pau-brasil?

5. Why did you plant pau-brasil and not another tree species?

6. Do you think other farmers are interested in planting pau-brasil as well?

7. To your knowledge what is the main use of pau-brasil wood?

8. Do you know of any traditional use of pau-brasil?

9. Do you use pau-brasil (wood, leaves, bark, roots, seeds) for anything in specific?

10. Do you know any farmer that has planted pau-brasil mixed with other agricultural plants?

11. Do you think it is difficult to find space for planting pau-brasil within your agricultural area?

12. Does planting pau-brasil have any positive effect for you?

13. Which are the difficulties or challenges when planting pau-brasil?

\section{Forest ranger}

1. For how long have you been working as a forest ranger in this conservation area?

2. Has there ever been illegal logging, especially of pau-brasil, in this conservation area?

3. What are your observations regarding the pau-brasil population in this conservation area?

4. Are there any pau-brasil trees left in this conservation area?

\section{Plantation owners}

1. When did you start planting pau-brasil trees?

2. What was your main motivation to plant pau-brasil trees?

3. Are you planting pau-brasil in monocultures, agroforestry systems, or mixed tree plantations (silviculture)?

4. In how many plantations did you include or plant pau-brasil trees?

5. Are your plantations registered in the rural environmental cadaster (Cadastro Ambiental rural)?

6. What processes of registration are necessary for a future commercial use of your planted pau-brasil trees?

7. Do you plant other tree species in the same area and if so, which ones? What were your criteria for selecting the other tree species?

\section{Scientists (botany/taxonomy)}

1. Can the three morphotypes of Caesalpinia echinata be related to genetic variations?

2. How can it be explained that all the three morphotypes can only be found in Bahia?

3. Have you also researched relationships between morphotype and wood characteristics? Do you know any studies on this?

4. There was/is a brazilwood project developed by the Botanical Garden of Rio de Janeiro - do you know that project and is it still going on?

5. Has there ever been done an ecological analysis on pau-brasil occurrence (e.g. regarding soil, surrounding plant species, etc.) within the natural remnants of the Mata Atlântica?

6. Are distribution maps available of the natural remnants of pau-brasil populations?

7. In all your research on pau-brasil, have you found any traditional use of pau-brasil? 
8. How relevant is it to consider the genetic variations when establishing pau-brasil plantations?

\section{Scientists (geography)}

1. Do you know of any records of pau-brasil exportations from 1800 until today?

2. To your opinion how reliable are such kind of data regarding pau-brasil exportations and ship loads?

3. Based on your research is it possible to draw conclusions on whether pau-brasil was cut selectively or as part of clear cutting in the past?

4. Is it possible to draw conclusions from which regions of the Mata Atlântica pau-brasil was cut mainly for the export and why?

5. Did you ever find indications during your research that pau-brasil was used for barrels, e.g., sugar barrels?

6. Were there already regulating laws for pau-brasil before the $20^{\text {th }}$ century?

7. What were the typical trade routes in the past?

\section{Scientists (wood anatomy and wood identification)}

1. What are characteristic wood anatomy features of pau-brasil?

2. How can pau-brasil wood be distinguished and clearly identified from similar tropical wood species?

3. Based on your knowledge, is there a lot of illegal trade with pau-brasil?

4. What is the typical procedure to detect and identify illegal wood transportation and trade in Brazil?

5. How effective are the wood trade controls in Brazil and what are the main challenges?

6. Based on your research what are scientifically alternative wood species that could replace pau-brasil wood for string instrument bows?

7. Are these alternative species more abundant and not endangered or regulated by CITES?

\section{Scientists (forestry)}

1. Do you consider the wood quality of planted pau-brasil trees to be comparable to the wood quality of pau-brasil wood from natural forests?

2. What are the differences in wood quality and how can they be explained?

3. In your research projects did you examine annual increase of the heartwood of paubrasil?

4. What is the minimum age pau-brasil seedlings need to reach before they can be harvested for bow-making of stringed instruments? 
Appendix 5. International online survey

Table A5.1 Matrix of the international online survey

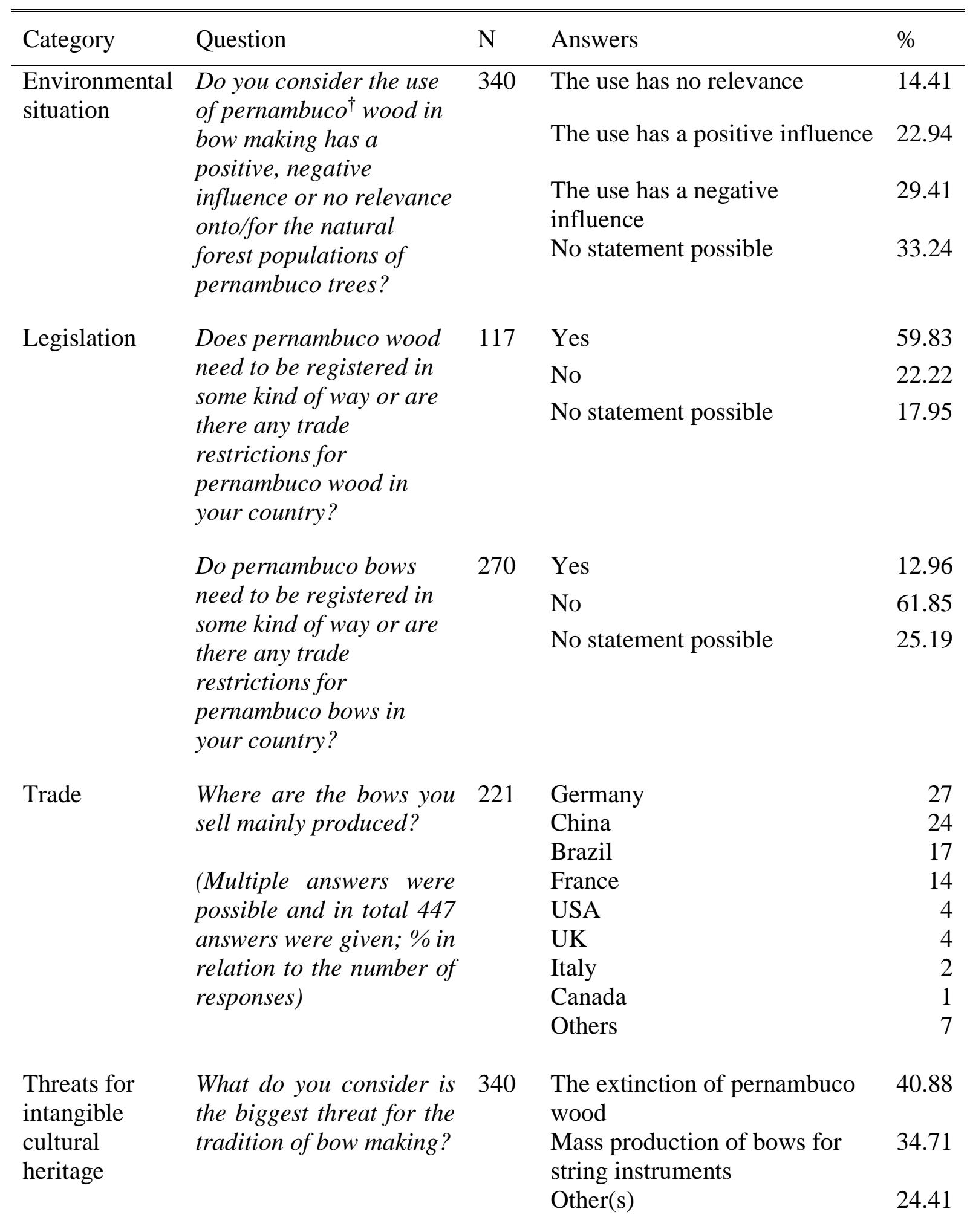


Age structure Which age group do you 338 Under $24 \quad 0.0$

of respondents belong to? 25-30 years 1.5

31-40 years $\quad 14.2$

41-50 years $\quad 25.7$

51-60 years $\quad 34.0$

Over 60 years 24.6

$\dagger$ In the survey the term pernambuco wood was used as synonym for pau-brasil, as this is the common term used by violin and bow makers. 
Appendix 6. Cross-scale social actor relation and power relation analysis

Table A6.1 Ecosystem services and Nature's Contributions for People (NCPs) provided by pau-brasil trees

\begin{tabular}{|c|c|c|c|c|}
\hline $\begin{array}{l}\text { Service } \\
\text { type }\end{array}$ & $\begin{array}{l}\text { Ecosystem goods and } \\
\text { services }\end{array}$ & $\begin{array}{l}\text { Source that indicates } \\
\text { the service provision }\end{array}$ & Benefits $\uparrow$ & $\begin{array}{l}\text { Benefitting } \\
\text { actor group }\end{array}$ \\
\hline \multirow[t]{4}{*}{$\begin{array}{l}\text { Material } \\
\text { NCP }\end{array}$} & $\begin{array}{l}\text { Wood for string } \\
\text { instrument bows }\end{array}$ & Rocha 2004 & $\begin{array}{l}\text { Material } \\
\text { (string } \\
\text { instrument } \\
\text { bows) }\end{array}$ & $\begin{array}{l}\text { Bow/violin } \\
\text { makers, } \\
\text { musicians, } \\
\text { audience }\end{array}$ \\
\hline & $\begin{array}{l}\text { Bark and leaves of } \\
\text { potential pharmaceutical } \\
\text { value, e.g., for cancer } \\
\text { treatment (not yet } \\
\text { commercially used) }\end{array}$ & $\begin{array}{l}\text { Grangeiro 2009, Zanin } \\
\text { et al. 2012, da Silva } \\
\text { Gomes et al. 2014, } \\
\text { Siqueira et al. 2014, } \\
\text { Fraga Campos et al. } \\
2015\end{array}$ & $\begin{array}{l}\text { Material } \\
\text { (medicine) }\end{array}$ & $\begin{array}{l}\text { Pharmacy, } \\
\text { patients }\end{array}$ \\
\hline & Wood used for red dye & Rocha 2004 & $\begin{array}{l}\text { Material } \\
\text { (red dye) }\end{array}$ & $\begin{array}{l}\text { Bourgeoisie } \\
\text { in Europe }\end{array}$ \\
\hline & $\begin{array}{l}\text { Value for the Brazilian } \\
\text { indigenous tribe } \\
\text { 'tupinambá' }\end{array}$ & $\begin{array}{l}\text { Bueno 2002, Buono } \\
\text { 2012, } 2016\end{array}$ & $\begin{array}{l}\text { Material } \\
\text { (red dye) }\end{array}$ & $\begin{array}{l}\text { Indigenous } \\
\text { tribe } \\
\text { 'tupinamba' }\end{array}$ \\
\hline \multirow[t]{4}{*}{$\begin{array}{l}\text { Non- } \\
\text { material } \\
\text { NCP }\end{array}$} & $\begin{array}{l}\text { Source of inspiration } \\
\text { mainly in Brazil (poetry, } \\
\text { compositions, labelling) }\end{array}$ & $\begin{array}{l}\text { Pinheiro 1991, Silva } \\
\text { and Andrade 2006, } \\
\text { Allen } 2011\end{array}$ & $\begin{array}{l}\text { Poetry, } \\
\text { composition, } \\
\text { music, etc. }\end{array}$ & $\begin{array}{l}\text { Artists, } \\
\text { 'audience' }\end{array}$ \\
\hline & $\begin{array}{l}\text { Intangible cultural value } \\
\text { for Brazilians (identity } \\
\text { and representation of } \\
\text { history of exploitation) }\end{array}$ & $\begin{array}{l}\text { Retford 1964, Bueno } \\
\text { 2002, Rocha et al. } \\
\text { 2007, UNESCO 2012, } \\
\text { Dapson and Bain } \\
2015\end{array}$ & $\begin{array}{l}\text { Identity, } \\
\text { place/ } \\
\text { heritage }\end{array}$ & $\begin{array}{l}\text { Residents of } \\
\text { Brazil }\end{array}$ \\
\hline & $\begin{array}{l}\text { Traditional knowledge in } \\
\text { violin- and bow-making } \\
\text { craftsmanship based on } \\
\text { pau-brasil use }\end{array}$ & Own research finding & $\begin{array}{l}\text { Knowledge, } \\
\text { identitiy, } \\
\text { employment, } \\
\text { bequest }\end{array}$ & $\begin{array}{l}\text { Bow/violin } \\
\text { makers, } \\
\text { musicians, } \\
\text { audience }\end{array}$ \\
\hline & $\begin{array}{l}\text { Classical music played } \\
\text { with string instruments } \\
\text { and pau-brasil bows (part } \\
\text { of Europeans identity) }\end{array}$ & Own research finding & $\begin{array}{l}\text { Knowledge, } \\
\text { employment, } \\
\text { bequest }\end{array}$ & $\begin{array}{l}\text { Musicians, } \\
\text { audience }\end{array}$ \\
\hline
\end{tabular}




\begin{tabular}{|c|c|c|c|}
\hline $\begin{array}{l}\text { Research (e.g., ecology, } \\
\text { taxonomy, history, } \\
\text { geography, wood } \\
\text { anatomy, material } \\
\text { science), education } \\
\text { (plantings of pau-brasil } \\
\text { trees and in front of } \\
\text { schools and in parks) }\end{array}$ & $\begin{array}{l}\text { Publications found } \\
\text { with Scopus with the } \\
\text { search string: } \\
\text { "Caesalpinia } \\
\text { echinata" OR } \\
\text { "brazilwood" OR } \\
\text { "pau-brasil" OR } \\
\text { "pernambuco wood" } \\
\text { OR "Paubrasilia } \\
\text { echinata": } 205\end{array}$ & $\begin{array}{l}\text { Knowledge, } \\
\text { bequest }\end{array}$ & $\begin{array}{l}\text { Scientists, } \\
\text { teachers, } \\
\text { students, } \\
\text { residents }\end{array}$ \\
\hline
\end{tabular}

$\lceil$ According to the categories of benefits (material, aesthetic, place/heritage, activity, spiritual, inspiration, knowledge, existence/bequest, option, social capital \& cohesion, identity, employment by (Chan et al. 2012). 
Table A6.2 Key actor groups and their formal institutionalizations (INT=international, EU=Europe, BRA=Brazil, MA=Mata Atlântica, Reg=regional)

\begin{tabular}{|c|c|c|}
\hline Actor groups & Formal organization/institution & Scale \\
\hline \multirow[t]{10}{*}{$\begin{array}{l}\text { Policymakers / } \\
\text { environmental agencies }\end{array}$} & $\begin{array}{l}\text { Convention on International Trade in Endangered } \\
\text { Species of Wild Fauna and Flora (CITES) }\end{array}$ & INT \\
\hline & $\begin{array}{l}\text { Council regulations of the European Union (European } \\
\text { government) }\end{array}$ & EU \\
\hline & Brazilian government & BRA \\
\hline & Brazilian Institute of the Environment and Renewable & BRA \\
\hline & Natural Resources (Instituto Brasileiro do Meio & \\
\hline & $\begin{array}{l}\text { Ambiente e dos Recursos Naturais Renováveis, } \\
\text { IBAMA) }\end{array}$ & \\
\hline & $\begin{array}{l}\text { Chico Mendes Institute for Biodiversity Conservation } \\
\text { (Instituto Chico Mendes de Conservação da } \\
\text { Biodiversidade, ICM-Bio) }\end{array}$ & BRA \\
\hline & $\begin{array}{l}\text { Programa Nacional de Conservação do Pau Brasil - } \\
\text { Programa Arboretum }\end{array}$ & BRA \\
\hline & Provincial governments (regional) & Reg. \\
\hline & Regional governments (local) & local \\
\hline \multirow[t]{3}{*}{ Scientists } & International Union for Conservation of Nature (IUCN) & INT \\
\hline & Botanical Garden of Rio de Janeiro & MA \\
\hline & Instituto Florestal Sao Paulo & BRA \\
\hline \multirow[t]{9}{*}{ Environmental NGOs } & $\begin{array}{l}\text { International Alliance of violin and bow makers for } \\
\text { endangered species }\end{array}$ & INT \\
\hline & $\begin{array}{l}\text { International Pernambuco Conservation Initiative } \\
\text { (IPCI) }\end{array}$ & INT \\
\hline & $\begin{array}{l}\text { Confederation of Craftsmen and Users of Natural } \\
\text { Resources (Comurnat), }\end{array}$ & EU \\
\hline & $\begin{array}{l}\text { International Pernambuco Conservation Initiative } \\
\text { (IPCI) }\end{array}$ & EU \\
\hline & Fundação Nacional do Pau-Brasil (FUNBRASIL) & MA \\
\hline & Association of Plants from the Northeast (APNE) & MA \\
\hline & Instituto Floresta Viva & MA \\
\hline & Programa Pau-brasil (CEPLAC) & MA \\
\hline & Instituto Verde Brasil & MA \\
\hline \multirow[t]{3}{*}{ Violin and bow makers } & $\begin{array}{l}\text { International Association of Violin and Bow makers } \\
\text { (EILA) }\end{array}$ & INT. \\
\hline & $\begin{array}{l}\text { Violin and Bow making associations of each European } \\
\text { country }\end{array}$ & EU \\
\hline & No formal organization within Brazil & BRA \\
\hline \multirow[t]{3}{*}{ Musicians } & International Federation of Musicians & INT. \\
\hline & European Music Council (EMC) & EU \\
\hline & No formal organization of Brazilian musicians & BRA \\
\hline $\begin{array}{l}\text { Farmers and plantation } \\
\text { owners }\end{array}$ & $\begin{array}{l}\text { No formal organization on the level of the whole Mata } \\
\text { Atlântica (only local farmers associations) }\end{array}$ & BRA \\
\hline Residents & No formal organization encompassing pau-brasil & MA \\
\hline
\end{tabular}




\section{Social actor and power relations matrix}

Table A6.3 Social actor and power relations of key actor groups considering: (1) the level of dependence from pau-brasil's NCPs/ESs ( 3 = highly dependent on material and non-material NCP/ES provided by pau-brasil for livelihoods of actor groups, 2 = moderately dependent on pau-brasil's immaterial NCPs/ESs, 1 = low dependence on pau-brasil as species, as the topic of their work is replaceable), (2) the level of influence on decision making processes regarding the management of pau-brasil's NCPs/ESs ( 3 = very large influence through active participation in decision/policy-making processes related to the management of NCPs/ESs implemented and mediated by formal institutions; 2 = moderate (subtle) influence; 1 = limited influence; 0 = no influence), and (3) a dependence-influence matrix indicating the level of disadvantage within the Mata Atlântica (MA), Europe (EUR) and internationally (INT)

\begin{tabular}{|c|c|c|c|c|c|c|c|c|c|c|}
\hline \multirow[t]{2}{*}{ Actor groups } & \multicolumn{3}{|c|}{$\begin{array}{l}\text { Level of } \\
\text { dependence }\end{array}$} & \multicolumn{2}{|c|}{$\begin{array}{l}\text { Level of } \\
\text { influence }\end{array}$} & & \multicolumn{3}{|c|}{$\begin{array}{l}\text { Dependence-Influence } \\
\text { (x-axis/y-axis) }\end{array}$} & \multirow[t]{2}{*}{$\begin{array}{l}\text { Level of } \\
\text { disadvantage }\end{array}$} \\
\hline & MA & EUR & INT & MA & EUR & INT & MA & EUR & INT & \\
\hline $\begin{array}{l}\text { Policymakers / } \\
\text { environmental } \\
\text { agencies }\end{array}$ & 1.5 & - & 1 & 3 & 3 & 3 & $1.5 / 3$ & $-/ 3$ & $1 / 3$ & low \\
\hline Scientists & 1.5 & 1 & 1.5 & 1 & 1 & 1 & $1.5 / 1$ & $1 / 1$ & $1,5 / 1$ & low \\
\hline $\begin{array}{l}\text { Environmental } \\
\text { NGOs }\end{array}$ & 1.5 & 1.5 & 1.5 & 1 & 2 & 1 & $1.5 / 1$ & $1.5 / 2$ & $1,5 / 1$ & low \\
\hline Violin makers & 2.5 & 2.5 & 2.5 & 1 & 2 & 1 & $2.5 / 1$ & $2.5 / 2$ & $2.5 / 2$ & high \\
\hline Bow makers & 3 & 3 & 3 & 1 & 2 & 1 & $3 / 1$ & $3 / 2$ & $3 / 1$ & very high \\
\hline Musicians & 2.5 & 2.5 & 2.5 & 1 & 2 & 1 & $2.5 / 1$ & $2.5 / 2$ & $2.5 / 1$ & high \\
\hline $\begin{array}{l}\text { Farmers and } \\
\text { plantation } \\
\text { owners }\end{array}$ & 2 & - & - & 2 & - & - & $2 / 2$ & - & - & moderate \\
\hline $\begin{array}{l}\text { Residents of the } \\
\text { MA }\end{array}$ & 1.5 & - & - & 2 & - & - & $1.5 / 2$ & - & - & low \\
\hline
\end{tabular}




\section{Descriptive social relations and power relations analysis}

Based on our interviews, we identified the following most relevant social actor groups: bow makers, environmental NGOs, musicians and violin makers, farmers and plantation owners, residents of the Mata Atlântica, scientists and policy makers (Table. A3.1). The farmers and plantation owners as well as the residents of the Mata Atlântica can only be found at the scale of the subsystem Mata Atlântica, all other actor groups are represented at all three scales (Fig. 1). As described by Peterson (2000), actor groups are usually quite heterogenous and can be subdivided considering hierarchical taxonomic distinctions. In our case, the Brazilian string bow manufactories represent one of these subgroups of the bow makers, since they act simultaneously as bow makers, wood traders, and some additionally as private plantation owners and members of environmental NGOs. Another case is the NGO IPCI, a subgroup of the environmental NGOs, consisting mainly of bow makers, violin makers, and musicians (actors that also form part of other actor groups), hence it follows a main interest (a commercial provision of pau-brasil wood in the future) when supporting pau-brasil conservation. Furthermore, IPCI is one of the most important supporters of pau-brasil planting projects.

Similarly to Martín-López et al. (2019), yet limited to one tree species, we define dependence as the degree of reliance on pau-brasil and its ecosystem services of a certain actor group for their livelihoods or well-being (Table A6.3). Our most important finding regarding the dependence level assessment is that the bow makers, in numbers a relatively small group of actors (there are globally only a bit more than 200 bow makers (Pfeifer 2002, Rymer 2004)), are most dependent at all scales ( 3 = high dependence) on the availability of pau-brasil wood with limited options of using alternative materials. Musicians and violin makers are also highly dependent on pau-brasil at all scales (2.5 = high-moderate dependence) but their dependence is spread to other raw materials and species in comparison to bow makers. The decision makers in the European subsystem implement the regulations of CITES but are not specifically concerned about pau-brasil as a species, so they do not appear at the European scale. Specific regulations and laws only for pau-brasil in Brazil show that pau-brasil is part of the work of some decision makers of the Mata Atlântica $(1=$ low dependence). The listing of pau-brasil in the Appendix II of CITES shows that pau-brasil occupies decision-makers in their work at the global scale ( 1 = low dependence). Within the subsystem of the Mata Atlântica, residents, farmers, and plantation owners in the Mata Atlântica depend on supporting and provisioning ecosystem services (such as nutrient cycling, soil formation, pollination and fuel wood), although not directly on the species of pau-brasil. Regarding cultural identity, pau-brasil is, by being the eponym and national tree of the country, of utmost relevance for residents, farmers and Brazilian plantation owners ( 2 = moderate - key relevance of pau-brasil and its ecosystem services but not directly for the livelihood). Regardless of their dependence, farmers and plantation owners influence the Mata Atlântica ecosystem with their management strategies and might induce land-use changes to increase their agricultural areas and thus sacrifice land of the Mata Atlântica.

International decision makers and the ones of the Mata Atlântica show the largest influence on the CES ( 3 = high influence), being responsible for relevant legislative decisions (CITES listing, laws regarding pau-brasil). In Europe, decisions at the international scale are implemented ( 3 = high influence). Considering our spatiotemporal analysis, bow makers, musicians, and violin makers were able to increase their influence level with the foundation of IPCI and the International Alliance, which was facilitated due to the historically existing formal international and European organizations, e.g., in guilds and associations (International: EILA, Europe: associations of professions) of these social actor groups. Therefore, they show a 
moderate influence ( 3 = moderate) on pau-brasil management strategies internationally and in Europe and even on decisions of CITES (e.g., excluding the finished product of string instrument bows from the CITES regulations in the Annotation \#10). Partly due to a missing formal association of bow makers in the Mata Atlântica or Brazil their level of influence is limited. Environmental NGOs show a moderate influence at all scales, while farmers and plantation owners, organized in different local associations, show a moderate influence within the Mata Atlântica but have internationally and in Europe no influence at all. Residents as well as musicians and bow makers of the Mata Atlântica have a very limited influence and residents have no influence in Europe or internationally. In contrast to that, the musicians and bow makers are better organized in Europe and internationally and show a moderate influence at these scales. Scientists at the international level have a large influence and represent the interests on pau-brasil as species influencing listings in the IUCN red list and with further participation in the CITES meetings also decisions on the listings in the appendices with direct implications on management strategies for its conservation. While the influence level is very limited at the European subsystem and limited within the Mata Atlântica subsystem both subsystems contribute through their cross-scale connection to the international influence level. We found that cross-scale interconnections between the same actor groups at different scales increase their influence especially on decisions taken at the global scale with local impacts (e.g., scientists, bow makers).

Our analysis indicates that historic considerations allow to identify changes in the influence level and instruments that empower actor groups. The direct and non-replaceable dependence of the entire profession of bow-makers on that specific primary raw material coupled with limited to moderate influence levels, makes them the most vulnerable actor group (highest dependency, as defined by Martín-López et al. (2019)) at all scales for this CES. But bow makers were able to decrease their vulnerability by increasing their influence level at all scales within the last 20 years by founding an interest oriented environmental NGO (IPCI) in 2000 and in 2018 the 'International Alliance of violin and bow makers for endangered species'. We found that existing formal associations that represent the interests of certain actor groups increase their possibilities to influence decision-making processes, high dependencies unify the interest and help to unite actors. Unconscious and immaterial dependencies on ecosystem services of pau-brasil, as in case of farmers and plantation owners and even more of residents of the Mata Atlântica, are usually ignored by the actors themselves. Additionally, e.g., the residents are formally not organized which seem to be one aspect of their low influence level as social actors of the CES.

Unequal distributed stocks of pau-brasil between the bow makers at all scales contribute to a lack of distributional equity within its social actor group and strategies to face that inequity should be faced. Possible factors might be age (young bow makers hardly have big stocks of pau-brasil wood), gender (bow making is a traditional male profession), and origin (being from a traditional bow making family might provide you with a stock of pau-brasil wood); however, this requires further analysis. For sustainable conservation strategies, increasing the interest of and even more the stake of these 'unconsciously' dependent actor groups might help to increase changes for a transformation process that equalizes also historical inequalities traceable back to colonization. A conscious participation and exchange with farmers and plantation owners and residents of the Mata Atlântica might also increase distributional and especially procedural equity. The PB-CES represents an example for international decision makers (CITES and UNESCO) and social actors (bow makers, NGO IPCI) at the international level having a greater interest in the sustainable management and species protection than local actors (farmers and plantation owners, as well as residents of the Mata Atlântica). 


\section{Legal framework represents manifested power structures}

Table A6.4 Relevant laws and conventions regarding pau-brasil and the tradition of bow making considering the international level (INT), Brazil (BRA), European Union (EU), the Mata Atlântica biome (MA), and the state of Bahia (BA).

\begin{tabular}{|c|c|c|c|c|}
\hline Туре & Scale & Year & $\begin{array}{l}\text { International } \\
\text { conventions, laws, and } \\
\text { regulations }\end{array}$ & $\begin{array}{l}\text { Implications for pau-brasil and/or bow } \\
\text { making }\end{array}$ \\
\hline \multirow[t]{4}{*}{$\begin{array}{l}\text { Int. } \\
\text { Con. } \dagger\end{array}$} & INT & 1998 & $\begin{array}{l}\text { IUCN Red list of } \\
\text { threatened species, } \\
\text { pau-brasil status: } \\
\text { endangered }\end{array}$ & $\begin{array}{l}\text { Recognition of international threat status } \\
\text { of pau-brasil being an endangered species. }\end{array}$ \\
\hline & & 1999 & $\begin{array}{l}\text { UNESCO declares } \\
\text { Discovery Atlantic } \\
\text { Forest Reserves as } \\
\text { Natural World } \\
\text { Heritage Site }\end{array}$ & $\begin{array}{l}\text { International protection status for these } \\
\text { areas of the MA including reserves with } \\
\text { important natural Paubrasilia echinata } \\
\text { occurrence. }\end{array}$ \\
\hline & & 2007 & $\begin{array}{l}\text { Pau-brasil listing in } \\
\text { CITES, Appendix II }\end{array}$ & $\begin{array}{l}\text { Laws for pau-brasil trade restrictions must } \\
\text { be implemented in each member country. }\end{array}$ \\
\hline & & 2012 & $\begin{array}{l}\text { UNESCO declares } \\
\text { Traditional Violin } \\
\text { Craftsmanship in } \\
\text { Cremona as Intangible } \\
\text { Cultural Heritage of } \\
\text { Humanity }\end{array}$ & $\begin{array}{l}\text { International recognition of that craft with } \\
\text { mainly local implications for the city of } \\
\text { Cremona and violin makers from } \\
\text { Cremona with their own trademark, not } \\
\text { specifically attributing the bow making } \\
\text { craftsmanship. }\end{array}$ \\
\hline \multirow[t]{2}{*}{ Trade } & BRA & 1986 & DECRETO Nº 92.446 & Legal implementation of CITES. \\
\hline & EU & 1997 & $\begin{array}{l}\text { VO (EU) 2017/160 } \\
\text { (EU Wildlife trade } \\
\text { regulation) }\end{array}$ & $\begin{array}{l}\text { Legal implementation of CITES in the } \\
\text { subsystems of the CES with consequences } \\
\text { for pau-brasil protection, trade } \\
\text { regulations, and travels of musicians, } \\
\text { violin, and bow makers. }\end{array}$ \\
\hline \multirow[t]{4}{*}{ Forest } & BRA & 1965 & LEI N ${ }^{o} 4.771$ & $\begin{array}{l}\text { Forest Code that mainly regulates forest } \\
\text { use and its protection with implications for } \\
\text { the protection for pau-brasil. }\end{array}$ \\
\hline & & 1978 & LEI N ${ }^{\circ} 6.607$ & National tree pau-brasil (pau-brasil). \\
\hline & & 1992 & $\begin{array}{l}\text { Portaria IBAMA } \\
\mathrm{N}^{0} 06-\mathrm{N}\end{array}$ & $\begin{array}{l}\text { Paubrasilia echinata listed as endangered } \\
\text { species. }\end{array}$ \\
\hline & & 2012 & PORTARIA No 320 & $\begin{array}{l}\text { National Conservation Program of pau- } \\
\text { brasil to enforce its protection and } \\
\text { regeneration. }\end{array}$ \\
\hline
\end{tabular}


2015 INSTRUÇÃO

NORMATIVA No 9

MA $2006 \quad$ LEI No 11.428

2008 DECRETO N 6.660

BA 2014 DECRETO No 15.180 Bahia state law for the cocoa agroforestry

Agr. BRA 2014 DECRETO No 8.235 Rural Environmental land register areas: 2014 PORTARIA MMA
N $^{\circ} 443$

2014 IBAMA

INSTRUÇÃO

NORMATIVA $N^{\circ} 21$

Seeds BRA $2003 \quad$ LEI N 10.711 systems that enables using pau-brasil from these agricultural areas.

Allows the commercial use of naturally fallen protected tree species (rare incident). This is a possible occasional chance for a legal and sustainable use of pau-brasil.

Law of Atlantic Forest, specifically protects the biome thus also pau-brasil.

Exploitation and ecological enrichment of Mata Atlântica - relevance for the protection of pau-brasil, complicating commercial use of native species.

(Cadastro Ambiental Rural (CAR)).

Regulates the use of cultivated endangered plant species, it directly affects pau-brasil and bow making due to difficulties with commercial plantations and a legal future use.

Control of exploitation, use and commercialization of products derived from planted native species with the introduced new Forest Control System.

Regulation of seed collection, reproduction, and nurseries to protect natural populations; however, it also complicates the planting of pau-brasil.

$\dagger$ Int. Con. $=$ International conventions

+ Agr. areas $=$ Agricultural areas

\section{Literature cited}

Allen, Aaron S. (2011): Prospects and Problems for Ecomusicology in Confronting a Crisis of Culture. In: Journal of the American Musicological Society 64 (2), S. 414-424. DOI: 10.1525/jams.2011.64.2.414.

Bueno, Eduardo (2002): Pau-Brasil. São Paulo: Axis Mundi Ed.

Buono, Amy J. (2012): Crafts of Color. Tupi Tapirage in Early Colonial Brazil. In: Andrea Feeser, Maureen Daly Goggin, Ms. Andrea Feeser und Assoc. Michael E. Yonan (Hg.): 
The Materiality of Color. The Production, Circulation, and Application of Dyes and Pigments, 1400-1800. Florence: Taylor and Francis (Histories of Material Culture and Collecting, 1700-1950), zuletzt geprüft am 01.11.2019.

Buono, Amy J. (2016): Representing the Tupinambá and the Brazilwood Trade in SixteenthCentury Rouen. In: Regina R. Felix und Scott D. Juall (Hg.): Cultural Exchanges between Brazil and France. West Lafayette, Indiana: Purdue University Press (Comparative cultural studies), zuletzt geprüft am 01.11.2019.

Chan, Kai M.A.; Satterfield, Terre; Goldstein, Joshua (2012): Rethinking ecosystem services to better address and navigate cultural values. In: Ecological Economics 74, S. 8-18. DOI: 10.1016/j.ecolecon.2011.11.011.

da Silva Gomes, Elisangela Christhianne Barbosa; Jimenez, George Chaves; da Silva, Luis Claudio Nascimento; Sá, Fabrício Bezerra de; Souza, Karen Pena Cavalcanti de; Paiva, Gerson S.; Souza, Ivone Antônia de (2014): Evaluation of antioxidant and antiangiogenic properties of caesalpinia echinata extracts. In: Journal of Cancer 5 (2), S. 143-150. DOI: 10.7150/jca.7439.

Dapson, Rw; Bain, Cl (2015): Brazilwood, sappanwood, brazilin and the red dye brazilein: from textile dyeing and folk medicine to biological staining and musical instruments. In: Biotechnic \& Histochemistry 90 (6), S. 401-423. DOI: 10.3109/10520295.2015.1021381. Fraga Campos, Fernanda; Sales Junior, Policarpo A.; Romanha, Alvaro José; Araújo, Márcio S. S.; Siqueira, Ezequias P.; Resende, Jarbas M. et al. (2015): Bioactive endophytic fungi isolated from Caesalpinia echinata Lam. (Brazilwood) and identification of beauvericin as a trypanocidal metabolite from Fusarium sp. In: Memorias do Instituto Oswaldo Cruz 110 (1), S. 65-74. DOI: 10.1590/0074-02760140243.

Grangeiro, Ana Ruth Sampaio (2009): Avaliação do potencial toxicológico e farmacológico de Caesalpinia echinata Lam., zuletzt geprüft am 06.05.2020.

Martín-López, Berta; Felipe-Lucia, María R.; Bennett, Elena M.; Norström, Albert; Peterson, Garry; Plieninger, Tobias et al. (2019): A novel telecoupling framework to assess social relations across spatial scales for ecosystem services research. In: Journal of environmental management 241, S. 251-263. DOI: 10.1016/j.jenvman.2019.04.029.

Peterson, Gary (2000): Political ecology and ecological resilience: An integration of human and ecological dynamics. In: Ecological Economics 35, S. 323-336. Online verfügbar unter http://www.sciencedirect.com/science/article/pii/S0921800900002172.

Pfeifer, Ellen (2002): Violin Bows Go High Tech: The Wall Street Journal.

Pinheiro, Amálio (1991): Tradução científica, tradução cultural, tradução poética. In: Revista USP, zuletzt geprüft am 04.05.2020.

Retford, William C. (1964): Bows and Bow makers. 1. Aufl. London: Strad.

Rocha, Yuri T.; Presotto, Andrea; Cavalheiro, Felisberto (2007): The representation of Caesalpinia echinata (Brazilwood) in Sixteenth-and-Seventeenth-Century Maps. In: $A n$. Acad. Bras. Ciênc. 79 (4), S. 751-765. DOI: 10.1590/S0001-37652007000400014.

Rocha, Yuri Tavares (2004): Ibirapitanga: história, distribuição geográfica e conservação do pau-brasil (Caesalpinia echinata Lam., Leguminosae) do descobrimento à atualidade. Universidade de São Paulo, São Paulo. Faculdade de Filosofia, Letras e Ciências Humanas. 
Rymer, Russ (2004): Saving the music tree. Artists and instrument makers have banded together to rescue Brazil's imperiled pernambuco, the source of bows for violins, violas and cellos. In: Smithsonian Magazine April.

Silva, Alberto Jorge da Rocha; Andrade, Laise de Holanda Cavalcantede (2006): Cultural Significance of Plants in Communities Located in the Coastal Forest Zone of the State of Pernambuco, Brazil. In: Hum Ecol 34 (3), S. 447-465. DOI: 10.1007/s10745-006-9026-0.

Siqueira, Ezequias P.; Zani, Carlos L.; Maria, Tânia; Alves, Almeida; Patrícia, M.; Filho, Olindo A. Martins et al. (2014): Evaluation of the In vitro leishmanicidal and In vivo acute oral toxicity of the Caesalpinia echinata L. extracts as source of natural products against leishmaniasis. In: Journal of Natural Product and Plant Resource 4 (3), S. 30-38.

UNESCO (2012): Intergovernmental Commitee for the Safeguarding of the Intangible Cultural Heritage. Decisions. In: Convention for the Safeguarding of the Intangible Cultural Heritage, zuletzt geprüft am 06.05.2020.

Zanin, João L. Baldim; Carvalho, Bianca a. de; Martineli, Paloma Salles; dos Santos, Marcelo Henrique; Lago, João Henrique G.; Sartorelli, Patrícia et al. (2012): The genus Caesalpinia L. (Caesalpiniaceae): phytochemical and pharmacological characteristics. In: Molecules (Basel, Switzerland) 17 (7), S. 7887-7902. DOI: 10.3390/molecules17077887. 


\section{Appendix 7. Detailed descriptive historical trajectory}

\section{Pre-colonial ecocultural system in the Mata Atlântica and SES within Europe (before 1500)}

Pre-colonial land use within the Mata Atlântica, a social-ecological system was, according to Nehren (2011), characterized by ecologically sustainable land use of the pre-colonial Tupi and Guarani tribes living in the Mata Atlântica. They only carried out small-scale slash-and-burn agriculture that allowed the regeneration of vegetation and soil, and were otherwise specialized in hunting and gathering. In contrast, the social-ecological system in Europe was close to reaching an ecological threshold; according to Moore (2002) European Feudalism was characterized by a degraded environment and soil exhausting agricultural practices. Hence, a spatial solution, through internal and external colonization, was the response to this imminent ecological shift driven by pressures of the social system.

\section{Pau-brasil exploitation for dyes (1500 to 1800)}

Colonization in 1500 marks the beginning of telecoupling between the Mata Atlântica and Europe, as well as the economic period of pau-brasil (Rocha (2004), characterized by excessive exploitation (1500-1875) with far-reaching socio-economic and environmental consequences. The Portuguese soon recognized pau-brasil for its valuable red dye. According to Buono (2016), the indigenous people had been using pau-brasil as a colorant and must have introduced the French to pulping techniques; thus, pau-brasil quickly became the most important resource for the Europeans. The special political and economic importance of pau-brasil is represented by the monopoly of the Portuguese Crown (1549-1859) (Dean 1996) and by the Franco-Brazilian trade with the Tupi tribe from the Mata Atlantica in the $16^{\text {th }}$ century (Dickason 1984, Buono 2016). For the use as red dye, the red-colored pau-brasil heartwood was pulverized and then added to water and/or other chemical solutions. The colorant brazilein evolves from the oxidized chemical wood component brazilin; as soon as the wood is exposed to the air the colorant was dissolved and finally dyed the fabric (Dapson and Bain 2015). Pau-brasil replaced the qualitatively inferior (due to lower brazilin content) Asian Caesalpinia Sappan L.

As far as the environmental dimension is concerned, the Mata Atlântica passed through three phases of exploitation, or emerging economies, which reduced the forest areas during this period: the exploitation of pau-brasil (1500-1550), sugar cane production (1550-1720), and gold rush (1720-1790). In the same period, the classical music in Europe went through the epochs of Renaissance (1400-1600), Baroque (1600-1750) and Classics (1750-1830) and was closely linked to the dimension of traditional violin and bow making with the era of Baroque bows, which were still made by violin makers themselves. The tradition of violin making originated in Europe and evolved from the craft of constructing lutes, a common instrument in the $15^{\text {th }}$ century. The famous traditional violin craftsmanship in Cremona, Italy, goes back to Andrea Amati (1505-1577) with its most important representatives, the Amati, Guarneri and Stradivari family (Halbscheffel 2010). In the Renaissance and Baroque periods, concerts were intended primarily for small audiences and were reserved for the royal court. The first violin solo concerts and virtuous compositions for string instruments appeared in the classical epoch and the technical demands on the musicians increased. These changes in classical music led to more public music-making and general public audiences at the end of the 18th century (Skeaping 1955). According to Brémaud and Poidevin (2013), most probably baroque and later bows and western classical music would not have been able to develop as they did without the woods from Latin America, which are characterized by their very high density and rigidity. With the introduction of classical music to the Mata Atlântica region and to Brazil in general, at the beginning mainly Jesuit missionaries were favored; this contributed to an even stronger and 
reciprocal telecoupled connection at a cultural level beyond economic exploitation. At the end of the 18th century, a series of new trends emerged as a consequence of complex changes associated with the cross-continental pau-brasil system (not yet CES): (1) increasing availability of pau-brasil in Central Europe as an important raw material for red dye production, (2) continuous evolution and demand of improved instruments in western classical music. This paved the way for experimenting with pau-brasil and for its later sole usel for string bow making.

The invention of the 'modern violin bow' gives rise to the telecoupled PB-CES ( 1800 to 1900)

This period, like the romantic epoch in music (1820-1910), is described in the literature as a stormy and stressful period. Brazil, and with it the Mata Atlântica, was undergoing a transformation to the post-colonial period (1822-1889) and then to capitalism (1889-present day). Economically, the period was dominated by coffee production (1790-1860). During the classical period (1750-1830), musical compositions began to change and became more virtuosic, which required more demanding playing techniques from the musicians. In the romantic period, compositions for larger orchestras with more musicians were written, so that larger concert halls were needed for a bigger audience; also, because the general public access to classical music increased. In order to withstand these changes and to accommodate the larger concert halls, baroque violins had to be modernized to generate a louder sound. Around 1800, experiments were made with all kinds of bows made of different materials and in different shapes to meet technical and tonal expectations (Skeaping 1955). Niccolò Paganini (17821840) was one of the most famous violinists of this time, he developed and improved the technique of violin playing to an unprecedented perfection (Komission für Musikforschung 2013); he tried all kinds of bows in order to best meet the increasing technical demands. With bows for stringed instruments, three things happened simultaneously: 1) a change in the construction method and the shape of the bows, 2) the construction of bows became more standardized in material and size, and 3) bow making became an own professional specialization, implying that most violin makers no longer produced bows. According to Brémaud and Poidevin (2013), bow makers were pushed by violinists who wanted to endow their violin play with a full and sustained sound with equal force from one end of the bow stick to the other. The weakness at the tip of the baroque bows got solved by increasing the height of the bow head and by stabilizing them with a lengthened and arched bow stick (Brémaud and Poidevin 2013). The bow makers experimented with different tropical woods at the beginning and finally adopted pau-brasil as the ideal wood by being lighter and just as dynamic and by solving the problem of balance with the mentioned structural changes. A good bow considers all these aspects and is precisely constructed by hand and is aesthetically pleasing. At the end of the $18^{\text {th }}$ century, the Italian violinist Giovanni Batista Viotti (1755-1824) met the bow maker F.X. Tourte (1747-1835) in Paris and their mutual inspiration plus the experimentation with pau-brasil led to the new model of violin bows, i.e. the modern violin bow. During this time, musicians began to realize the importance of the bow for better sound quality (Mnatzaganain 2002). At the end of the $19^{\text {th }}$ century, G.B. Viotti summed this up with the words: "Le violon, c'est l'archet" - the violin, it is the bow. Baroque bows were never fully replaced by modern violin bows, as there are still musicians who play early baroque music with baroque bows. Some bow makers still construct baroque bows for this purpose using the original, traditionally used wood types. 
In the late $18^{\text {th }}$ century, bow making was still in its initial phase, but the French bow makers, especially in Paris, had relatively easy access to pau-brasil due to the still existing and important dye industry in France. From the beginning, they had a considerable economic advantage in comparison to their competitors in Germany and Britain (Bunn and Seiber 1997). A recent anatomical analysis of historical French bows originating from the time of F.X. Tourte (17471835) and shortly after, indicates that the pau-brasil, which was used for these precious bows, most probably had its origin in the northeast of Brazil (Macedo 2015, Macedo et al. 2020)). By the end of this period (1875-1972) pau-brasil was considered extinct. There is no evidence whether this was due to the collapsed pau-brasil demand and the consequential missing attention to the species or due to the continuous wood demand for bow making in a drastically decreased biome.

\section{The deceptive calm and flourishing bow making ( 1900 to 1998)}

From the $19^{\text {th }}$ century onwards, bow making spread throughout Europe but mainly in Germany, France and England; in Germany mainly in Markneukirchen in Saxony, in England in London, and in France in Mirecourt and Paris (Bunn and Seiber 1997). During this period bow and violin makers in Europe used pau-brasil without restrictions. Supply shortages occurred only during the First and the Second World War; however, they were not attributed to a decline in paubrasil populations. The musical epoch of modernism (1908-present day) encompasses a variety of music styles such as the twelve-tone technique, serial music, jazz, blues, electronic music and experimental music, among others (Brockhaus 1993). In musical instrument making, innovation and change was sought, but this was not induced by the scarcity of pau-brasil. Experiments with alternative materials for bows led to the first patent for bows made of carbon fiber by Claudio Righetti in 1989. However, bow makers and musicians perceive carbon fiber bows as inferior to pau-brasil bows with regard to playability, acoustic properties, haptics, and aesthetics. Nevertheless, the quality has improved significantly over the last 30 years (Femke 2014) and the market share of carbon fibre bows is continuously increasing. In the same period, triggered by the economic opening of China in 1978 (Lockett and Littler 1983), cheap, inferior musical instruments and bows, including pau-brasil bows, entered the international market (Hume 2008). Land use intensification and urbanization processes in large parts of the Mata Atlântica also explain substantial declines of pau-brasil populations during this period. However, there are no reliable data in this regard. Although according to Rocha (2004), paubrasil has been in a period of regeneration since 1972, the species was listed as endangered by the Brazilian Institute of the Environment and Renewable Natural Resources (Instituto Brasileiro do Meio Ambiente e dos Recursos Naturais Renováveis, IBAMA) in 1992. This measure was reinforced in 1998, when pau-brasil was included in the International Union for Conservation of Nature's (IUCN) Red List (Varty 1998) as an endangered species (EN A1 acd) due to overexploitation and decline of the species' population; this marked a regime shift for the PB-CES.

\section{Control of the PB-CES by intergovernmental protection and trade regulations (1998 to present day)}

The dominated intergovernmental control on pau-brasil protection was introduced by the listing of pau-brasil on the IUCN red list. In 1999, the Discovery Coast Atlantic Forest Reserves were listed as a UNESCO World Natural Heritage Site of Humanity, recognizing their value and the importance of their preservation. These reserves comprise the areas with the highest numbers of remaining natural pau-brasil populations and thus contribute to the recovery of the species by protecting them. UNESCO's international protection interest in these reserves of the Mata 
Atlântica strengthens the perception of their ecological importance and underlines the importance of maintaining their protection status. Also in 1999, Marco Ciambelli, the son of a tortoiseshell worker family in France, learned that the ecological situation of pau-brasil was very critical and that the species could possibly be listed in one of the CITES Appendices (Rymer 2007). He had witnessed the collapse of the family business after the listing of tortoiseshell in CITES and therefore passed this information on to bow makers in a meeting in Paris (Rymer 2004). This information and the alarming threat that pau-brasil could reach the status of trade restriction were responsible for bow makers to become active and to found the International Pernambuco Conservation Initiative (IPCI) in 2000 with 50 founding members from 18 nations and implementing reforestation and conservation projects for pau-brasil in the Mata Atlântica (Gerbeth 2002). However, pau-brasil was finally listed in Appendix II of CITES in 2007. Bow makers, mainly from IPCI (Rymer 2004) and internationally renowned musicians such as Yo-Yo Ma, achieved at the last minute that the final product of pau-brasil, the bow, was to be excluded from Annex II (Sadler 2007). Hence, the species pau-brasil is listed in Appendix II of CITES, but the final products made from its wood such as bows, have no restrictions on their marketing.

\section{Literature cited}

Brémaud, Iris; Poidevin, Nelly (2013): Approches culturelles et mecaniques dans le choix des bois en facture: cas des archets anciens. Music and its instruments. In: Michèle Castellengo und Hugues Genevois (Hg.): Lamusique et ses instruments. Sampzon: Editions Delatour France (Collection Pensée Musicale), S. 1-27.

Brockhaus (Hg.) (1993): Der Brockhaus in fünf Bänden. 8. Aufl. 5 Bände. Mannheim: F.A. Brockhaus GmbH (neubear).

Bunn, Julie; Seiber, Lydia Rose (1997): Music, makers and markets. In: The Strad.

Buono, Amy J. (2016): Representing the Tupinambá and the Brazilwood Trade in SixteenthCentury Rouen. In: Regina R. Felix und Scott D. Juall (Hg.): Cultural Exchanges between Brazil and France. West Lafayette, Indiana: Purdue University Press (Comparative cultural studies).

Dapson, Rw; Bain, Cl (2015): Brazilwood, sappanwood, brazilin and the red dye brazilein: from textile dyeing and folk medicine to biological staining and musical instruments. In: Biotechnic \& Histochemistry 90 (6), S. 401-423. DOI: 10.3109/10520295.2015.1021381.

Dean, Warren (1996): A ferro e fogo. A história e a devastação da mata atlântica brasileira. 6. Aufl. São Paulo: Companhia das letras.

Dickason, Olive Patricia (1984): The Brazilian connection. A look at the origin of French techniques for trading with Amerindians. In: outre 71 (264), S. 129-146. DOI: 10.3406/outre.1984.2435.

Femke, Colborne (2014): A Challenge to tradition. In: Accessories October, S. 4-7.

Gerbeth, Thomas M. (2002): Pernambuco Sonderausgabe. Verein Österreichischer Geigen- und Bogenmachermeister. Wien.

Halbscheffel, Bernward (2010): Lexikon Musikinstrumente Instrumente, Spielweisen, Begriffe. Leipzig: Halbscheffel Verlag.

Hume, David (2008): Quality and Quantity. In: The Strad October, S. 38-42. 
Komission für Musikforschung (2013): Österreichisches Musiklexikon. Wien: Verlag der Österreichischen Akademie der Wissenschaften. Online [URL]: http://www.musiklexikon.ac.at/ml/musik_P/Paganini_Niccolo.xml.

Lockett, Martin; Littler, Craig R. (1983): Trends in Chinese enterprise management, 19781982. In: World Development 11 (8), S. 683-704. DOI: 10.1016/0305-750X(83)90112-2.

Macedo, Tahysa Mota (2015): Variação intraespecífica do lenho e dendrocronologia de Caesalpinia echinata Lam. na Floresta Atlântica. Universidade Federal do Rio de Janeiro (UFRJ).

Macedo, Tahysa Mota; Costa, Cecília Gonçalves; Lima, Haroldo Cavalcante de; Barros, Claudia Franca (2020): Wood anatomy of historic French violin bows made of Pernambuco wood. In: IAWA J., S. 1-13. DOI: 10.1163/22941932-bja10011.

Martín-López, Berta; Felipe-Lucia, María R.; Bennett, Elena M.; Norström, Albert; Peterson, Garry; Plieninger, Tobias et al. (2019): A novel telecoupling framework to assess social relations across spatial scales for ecosystem services research. In: Journal of environmental management 241, S. 251-263. DOI: 10.1016/j.jenvman.2019.04.029.

Mnatzaganain, S. (2002): Objects of desire. In: The Strad 8, S. 816-820.

Moore, Jason W. (2002): The Crisis of Feudalism. In: Organization \& Environment 15 (3), S. 301-322. DOI: 10.1177/1086026602153008.

Nehren, Udo (2011): Historische Landschaftsdegradation und aktuelle Nutzungsproblematik in der Serra dos Órgãos, Rio de Janeiro. In: Neuburger, Martin Coy \& Martina (Hg.): Global Change: Herausforderungen für Lateinamerika. Bd. 38: Innsbrucker Geographische Studien, S. 11-25.

Peterson, Gary (2000): Political ecology and ecological resilience: An integration of human and ecological dynamics. In: Ecological Economics 35, S. 323-336. Online [URL]: http://www.sciencedirect.com/science/article/pii/S0921800900002172.

Pfeifer, Ellen (2002): Violin Bows Go High Tech: The Wall Street Journal.

Rocha, Yuri Tavares (2004): Ibirapitanga: história, distribuição geográfica e conservação do pau-brasil (Caesalpinia echinata Lam., Leguminosae) do descobrimento à atualidade. Universidade de São Paulo, São Paulo. Faculdade de Filosofia, Letras e Ciências Humanas.

Rymer, Russ (2004): Saving the music tree. Artists and instrument makers have banded together to rescue Brazil's imperiled pernambuco, the source of bows for violins, violas and cellos. In: Smithsonian Magazine April.

Rymer, Russ (2007): A fight for survival. In: The Strad June, S. 28-32.

Sadler, Naomi (2007): Endangered species. Naomi Sadler reports on a recent conference to decide whether to restrict the trade in pernambuco wood, and looks at what is being done to save Brazil's imperilled national tree. In: Double Bassist (43), S. 29-32.

Skeaping, Kenneth (1955): Some Speculations on a Crisis in the History of the Violin. In: The Galpin Society Journal Vol. 8, S. 3-12. DOI: 10.2307/842152.

Varty, N. (1998): Caesalpinia echinata. In: The IUCN Red List of Threatened Species, S. 1-10. DOI: 10.2305/IUCN.UK.1998.RLTS.T33974A9818224.en. 